MAÍRA MELLO REZENDE VALLE

\title{
Alterações na homeostase redox das células beta pancreáticas em resposta à glicose
}

Tese apresentada ao Programa de Pós-Graduação em Fisiologia Humana do Instituto de Ciências Biomédicas da Universidade de São Paulo, para a obtenção do Título de Doutor em Ciências.

São Paulo 
MAÍRA MELLO REZENDE VALLE

Alterações na homeostase redox das células beta pancreáticas em resposta à glicose

Tese apresentada ao Programa de Pós-Graduação em Fisiologia Humana do Instituto de Ciências Biomédicas da Universidade de São Paulo, para a obtenção do Título de Doutor em Ciências.

Área de Concentração: Fisiologia Endócrina

Orientador: Professor Dr. Angelo Rafael Carpinelli

Versão Original 
DADOS DE CATALOGAÇÃO NA PUBLICAÇÃO (CIP)

Serviço de Biblioteca e Informação Biomédica do

Instituto de Ciências Biomédicas da Universidade de São Paulo

reprodução não autorizada pelo autor

Valle, Maíra Mello Rezende.

Alterações na homeostase redox das células beta pancreáticas em resposta à glicose / Maíra Mello Rezende Valle. -- São Paulo, 2014.

Orientador: Prof. Dr. Angelo Rafael Carpinelli.

Tese (Doutorado) - Universidade de São Paulo. Instituto de Ciências Biomédicas. Departamento de Fisiologia e Biofísica. Área de concentração: Fisiologia Humana. Linha de pesquisa: Fisiologia da secreção de insulina.

Versão do título para o inglês: Modulation of the redox state by glucose in pancreatic beta cells.

1. Superóxido 2. NADPH oxidase 3. llhotas pancreáticas 4. Rac1

5. Sod1 6. Glicose I. Carpinelli, Prof. Dr. Angelo Rafael II.

Universidade de São Paulo. Instituto de Ciências Biomédicas.

Programa de Pós-Graduação em Fisiologia Humana III. Título. 
Candidato(a):

Título da Tese:
Maíra Mello Rezende Valle.

Alterações na homeostase redox das células beta pancreáticas em resposta à glicose.

Orientador(a): $\quad$ Prof. Dr. Angelo Rafael Carpinelli.

A Comissão Julgadora dos trabalhos de Defesa da Tese de Doutorado, em sessão pública realizada a ..................., considerou
( ) Aprovado(a)
( ) Reprovado(a)

\author{
Examinador(a): Assinatura: \\ Nome: \\ Instituição: \\ Examinador(a): Assinatura: \\ Nome: \\ Instituição: \\ Examinador(a): Assinatura: \\ Nome: \\ Instituição: \\ Examinador(a): Assinatura: \\ Nome: \\ Instituição: \\ Presidente: \\ Assinatura: \\ Nome: \\ Instituição:
}




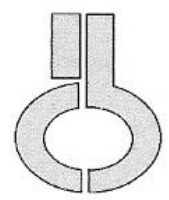

\section{Certificado}

Certificamos que o protocolo registrado sob $\mathrm{n}^{\circ} \mathbf{7 1}$ nas fls. $\mathbf{7 1}$ do livro $\mathbf{0 2}$ para uso de animais em experimentação, sob a responsabilidade do Prof(a) Dr(a) Ângelo Rafael Carpinelli, Coordenador(a) da Linha de pesquisa Possivel envolvimento da interação redox-sensivel Rac1/SOD1 na ativação de NOX2 no processo de secreção de insulina induzido por alta glicose do qual participou(aram) o(s) alunos Maira Mello Rezende Valle, Fernanda Rodrigues Graciano, Eduardo Rebelato Lopes de Oliveira e o pesquisador Rui Curi, está de acordo com os Princípios Éticos de Experimentação Animal adotado pela Sociedade Brasileira de Ciência de Animais de Laboratório (SBCAL) e foi aprovado pela COMISSÃO DE ÉTICA EM EXPERIMENTAÇÃO ANIMAL (CEEA) em 15.05.09, com validade de 3 anos.

São Paulo, 18 de maio de 2009.

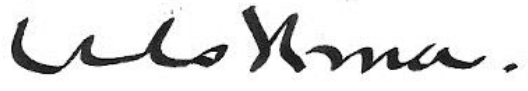

Prof.Dr.WoTHAN TAVARES DE LIMA Coordenador CEEA - ICB/USP

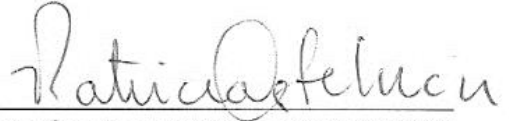

Profa.Dra.PATRÍCIA CASTELUCCI Secretária CEEA - ICB/USP 


\title{
UNIVERSIDADE DE SÃo PAULO
}

\section{INSTITUTO DE CIÊNCIAS BIOMÉDICAS}

Cidade Universitária "Armando de Salles Oliveira"

Av. Prof. Lineu Prestes, 2415 - cep. 05508-000 São Paulo, SP - Brasil

Telefone :(55) (011) 3091.7733 e-mail: cep@icb.usp.br

\section{Of.CEUA.063.12}

WTL/mcgn

São Paulo, 10 de agosto de 2012.

\section{REF.: Protocolo $n^{\circ} 071.09$.}

"Possivel envolvimento da interação redox-sensivel Racl/SODI na ativação de NOX2 no processo de secreção de insulina induzido por alta glicose".

Prezado Professor,

Informo que a sua licença para uso de animais em experimentação, constante no protocolo em epígrafe, foi prorrogada até $\underline{15.05 .2015 .}$

Reitero que havendo alteração de metodologia e inserção de novos alunos ao projeto de pesquisa vinculado à referida licença a CEUA/ICB deverá ser informada.

\section{Cordialmente,}

\author{
P) Bived
}

Prof. Dr. WOTHAN TA.VARES DE LIMA

Coordenador - CEUA-ICB/ /USP

IImo.Sr.

Prof. Dr. Angelo Rafael Carpinelli

Departamento de Fisiologia e Biofisica

Instituto de Ciências Biomédicas - USP 
Para minha mãe, Bel, onipresença em minha vida. E para o meu pai, Robson, que sempre me ilumina os caminhos. 


\section{AGRADECIMENTOS}

De tanta gente por agradecer nesse caminho tão longo, começo agradecendo a duas queridas amigas e companheiras, Fê e Lets, sem vocês não teria sido possível.

Depois sigo com as pessoas do laboratório, que se tornou minha segunda casa: Elo, Gabi, Camila, Dandam, Paty, Ana "Maria", Kathe e principalmente, a querida Má, mãezona de todos. Muito obrigada por tudo e desculpem qualquer coisa!

Ao professor Angelo, sempre tão generoso e compreensivo.

Minha adorada Leilinha, por todo apoio, conversas e carinho.

Minha família amada. Ficar longe não foi fácil... Obrigada pelo suporte, especialmente meus irmãos Janaína, João, Izabel e Eduardo, meu orgulho.

Ela não poderia deixar de ser citada aqui, a cadela mais maravilhosa do mundo: Morena, obrigada por deixar minha vida mais alegre!

Aos meus muitos amig@s: Aline, Arnaldo, Bel, Beto, Bruno, Cecília, Dani, Daniel, Daviane, Débora, Élida, Emma, Fabrícia, Fernando, Giselle, Hadassa, Isis, João, Juan, Lu, Lucas, Otávio, Paty, Renata Plim, Renatinha, Ston, Vivian, Wâninha, obrigada por todas as alegrias, tristezas e loucuras compartilhadas. Afinal, "que graça teria a vida se só houvesse dias ensolarados e amigos equilibrados?" C.F.A.

Ao Elder, que chegou já no fim, tão difícil, e mesmo assim se manteve ao meu lado.

Obrigada à Andreza, que vem me acompanhando e me ajudando a dar razão a um turbilhão de sentimentos que esse doutorado me gerou.

Agradeço também todo o suporte dado pelos funcionários e professores do ICB/USP, especialmente o Zé, sempre tão preocupado e comprometido com seu trabalho, e os professores Rui, Fernando e Carla sempre por boas ideias e ajuda prestada.

Por fim, um agradecimento especial a CAPES, Fulbright e FAPESP pelo apoio financeiro.

E a Deus, que me permitiu sempre ir em frente. 
"In physiology, as in all other sciences, no discovery is useless, no curiosity misplaced or too ambitious, and we may be certain that every advance achieved in the quest of pure knowledge will sooner or later play its part in the service of man." 


\section{RESUMO}

\section{VALLE, M. M. R. Alterações na homeostase redox das células beta pancreáticas em}

resposta à glicose. 2014. 97 f. Tese (Doutorado em Fisiologia Humana) - Instituto de Ciências Biomédicas, Universidade de São Paulo, São Paulo, 2014.

O oxigênio é bem conhecido como o aceptor final da cadeia transportadora de elétrons, processo que gera energia através da fosforilação oxidativa. Porém, o oxigênio também está presente em um conjunto de compostos químicos que coletivamente são chamados de espécies reativas de oxigênio (EROs), que podem ser altamente reativas e por isso podem causar danos tissulares, modificando moléculas e gerando perda de função das mesmas. Assim, as células ubiquamente expressam componentes antioxidantes que protegem o organismo contra os efeitos deletérios das EROs. Quando a defesa antioxidante falha em eliminar as EROs excedentes, ocorre então o chamado estresse oxidativo, que se relaciona a inúmeras doenças como a aterosclerose e o diabetes. Entretanto, nos últimos anos tem ficado cada vez mais claro que os sistemas biológicos produzem EROs, através do complexo NADPH oxidase e da cadeia mitocondrial de transporte de elétrons, e que estas não são apenas nocivas, pois têm papeis fisiológicos, destacando dentre eles o da sinalização celular. As células beta pancreáticas, produtoras de insulina, são conhecidas por apresentarem uma defesa antioxidante menor quando comparada a outros tecidos, como o hepático. Apesar disso, expressam a NADPH oxidase e a produção de EROs já foi associada à secreção de insulina. No entanto, ainda não há clareza como a glicose (principal secretagogo da insulina) afeta o microambiente redox neste tecido endócrino. Sendo assim, decidimos avaliar o efeito da incubação por 1 ou 48 horas em diferentes concentrações de glicose $(2,8 ; 5,6 ; 8,3 ; 11,1$; 16,7 e $20 \mathrm{mM}$ ) nestas células. Através destes experimentos observamos que o conteúdo de superóxido é maior quanto menor a concentração de glicose, especialmente após 48 horas de incubação. O uso do inibidor de Rac1, NSC23766, diminuiu em $40 \%$ o conteúdo tanto para alta quanto para baixa glicose, mas não na ausência desta. Já o conteúdo de superóxido mitocondrial apresentou aumento em baixa glicose apenas com o estímulo agudo de 1 hora. A glicose também foi capaz de alterar o conteúdo celular de uma das principais moléculas antioxidantes, a glutationa reduzida, que aumenta com o aumento de glicose. O açúcar também foi capaz de modular a expressão de outras enzimas antioxidantes. A incubação in vitro em baixa glicose foi mais deletéria do que a alta glicose, levando ao aumento de apoptose nas ilhotas. A inibição de Sod1 inibiu a secreção de insulina, demonstrando que as alterações redox são capazes de afetar o processo secretório. As células beta pancreáticas apresentam a interação física entre as proteínas Rac1/Sod1, processo que colabora para a atividade da NADPH oxidase, sendo a associação maior em alta glicose, quando provavelmente o meio está reduzido, já que a interação só ocorre nesta condição. Por fim, estas células não apresentam endossomas redox, os redoxossomas, em resposta à glicose. Em conclusão, observamos que a glicose é capaz de alterar a homeostase redox das células beta pancreáticas, não só alterando a produção de EROs via NADPH oxidase e mitocôndria, mas também modulando o sistema antioxidante. Estas alterações podem afetar eventos chave para este tecido endócrino, como a secreção de insulina e a morte celular.

Palavras-chave: Ilhotas pancreáticas. Superóxido. Glicose. Espécies Reativas de Oxigênio. Nox2. Rac1. Sod1. 


\section{ABSTRACT}

\section{VALLE, M.M.R. Modulation of the redox state by glucose in pancreatic beta cells.}

2014. 97 p. Ph.D. Thesis (Human Physiology) - Instituto de Ciências Biomédicas, Universidade de São Paulo, São Paulo, 2014.

Oxygen is well known as the final acceptor of electrons in the mitochondrial electron transport chain that generates ATP through oxidative phosphorylation. Oxygen also leads to production of reactive oxygen species (ROS), which are very reactive and cause damage to tissues and cell dysfunction. Cells ubiquitously express antioxidant enzymes and produce antioxidant compounds that scavenge ROS and protect the cells against their deleterious actions. When the antioxidant defense capacity is not able to eliminate the exceeding ROS produced, oxidative stress occurs. This latter condition has been associated to the development of several diseases such as atherosclerosis and diabetes. Recent evidence indicates that ROS produced through either NADPH oxidase complex or mitochondrial electron transport chain also play an important physiological role as signaling molecules. Pancreatic beta cells present low antioxidant defense capacity when compared with other tissues, e.g. the liver, but also express NADPH oxidase complex. ROS production in these cells has been associated with the insulin secretion process induced by glucose. However, the mechanism by which glucose affects the redox microenvironment in these cells remains unknown. In order to address this issue, we evaluated the effect of 1 or 48 hours incubation of pancreatic beta cells with various glucose concentrations $(2.8,5.6,8.3,11.1,16.7$ and $20 \mathrm{mM})$. We found a linear decrease in superoxide production, especially after 48 hours by the increase in glucose concentrations. Pharmacological inhibition of Rac1 (using NSC23766) decreased by $30 \%$ superoxide production in high and low glucose concentrations but had no effect in its absence. The mitochondrial superoxide production by pancreatic islets was raised only in low glucose concentration (2.8 $\mathrm{mM}$ ) after 1 hour. High glucose concentration $(20 \mathrm{mM})$ led to an increase of the content of reduced glutathione, one of the main antioxidant compounds of the cells. Glucose also modulates the expression of antioxidant enzymes (Sod1, Sod2, catalase, glutathione peroxidase and thioredoxin). The in vitro incubation of pancreatic islets under low glucose (2.8 $\mathrm{mM}$ ) was more deleterious to cells as indicated by apoptosis than under high glucose. Pharmacological inhibition of Sod1 decreased glucose stimulated insulin secretion, showing that redox modifications do affect the secretory process of this hormone. The occurrence of the physical interaction between Rac 1 and Sod1 was confirmed in pancreatic beta cells through immuhistochemistry. This association plays a key role to maintain the NADPH oxidase complex activated. The interaction between these two signaling molecules in insulin producing cells is stronger under high glucose concentration. In fact, the binding between the two proteins is redox sensitive and occurs in reduced surroundings only as observed in high glucose. Finally, these cells do not present redox endosomes, the redoxosomes, in response to glucose loading. In conclusion, glucose controls the redox state of pancreatic beta cells by changing ROS production via NADPH oxidase and mitochondria and through modulation of the antioxidant defense capacity. These effects induced by glucose loading might be associated with the process of insulin secretion and pancreatic beta cell death.

Keywords: Pancreatic Islets. Superoxide. Glucose. Reactive Oxygen Species. Nox2. Rac1. Sod1. 


\section{LISTA DE ABREVIATURAS E SIGLAS}

ADP - adenosina difosfato

$\mathbf{A K T}$ - protein kinase $B$

ANOVA - analise de variância

ATP - adenosina trifosfato

BSA - Bovine serum albumin

CAT - catalase

$\mathrm{CO}_{2}$ - Dióxido de carbono

CT - Threshold cycle

DAPI - 4'-6-diamidino-2-fenilindol

DETC - dietilcarbamato de sódio

DHE - dihidroetidina ou diidroetídeo

DuOX - Dual oxidase

$\mathrm{ECL}$ - electrogenerated chemiluminescence

EDTA - ácido etilenodiamino tetra-acético

ELISA - enzyme-linked immunosorbent assay

EROs - espécies reativas de oxigênio

FADH - dinucleótido de flavina e adenina

GEF - Guanine nucleotide exchange factors

GPX - glutationa peroxidase

GR - glutationa redutase

GSH - glutationa reduzida

GSSH - glutationa oxidada

GTP - guanosina trifosfato

$\mathrm{HCl}$ - ácido clorídrico

HPLC - High-performance liquid chromatography

HPRT - hipoxantina fosforribosil transferase

$\mathrm{H}_{2} \mathrm{O}$ - água

$\mathrm{H}_{2} \mathrm{O}_{2}$ - Peróxido de hidrogênio

IgG - Imunoglobulina G

KRB -Krebs ringer buffer
MAPK - mitogen-activated protein kinase

Mn-TBAP - manganese(III)tetrakis(4-

benzoicacid)porphyrin

MTT - 3-(4,5-dimetiltiazol-2yl)-2,5-difenil brometo de tetrazolina

$\mathbf{N}_{\mathbf{2}}$ - nitrogênio

$\mathrm{NaCl}$ - Cloreto de Sódio

NADPH - nicotinamida adenina dinucleotídeo fosfato

$\mathrm{NO}^{\circ}$ - radical óxido nítrico

NOX - NADPH oxidase

NOXA - subunidade ativadora de Nox

NOXO - subunidade organizadora de Nox

$\mathrm{O}_{2}$ - oxigênio

$\mathrm{O}_{2}{ }^{\circ-}$ - radical ânion superóxido

$\mathbf{O}_{3}$ - ozônio

$\mathrm{OH}^{\circ}$ - radical hidroxil

PAGE - polyacrylamide gel electrophoresis

PBS - tampão fosfato-salino

PCR - Reação em cadeia da polimerase

phox - Phagocyte oxidase

PI3K - phosphatidylinositide 3-kinases

PKC - Protein Kinase C

PTP-1B - protein tyrosine phosphatase $1 B$

RAC - Ras-related C3 botulinum toxin substrate

RE - retículo endoplasmático

RhoGDI - Rho GDP dissociation inhibitor

RIPA - radioimmunoprecipitation assay

RPMI - Roswell Park Memorial Institute Medium

SDS - sodium dodecyl sulfate

SOD - superóxido dismutase 


\section{SUMÁRIO}

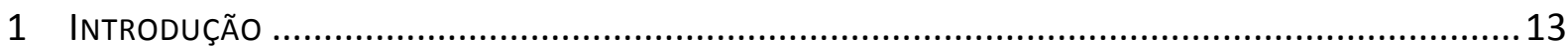

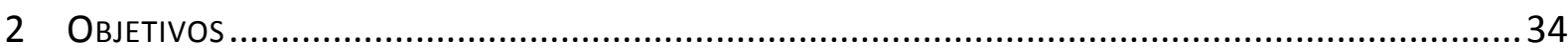

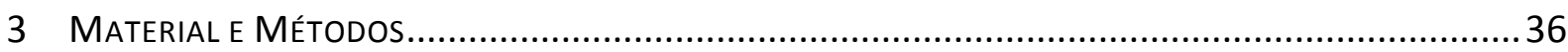

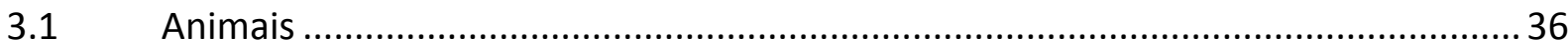

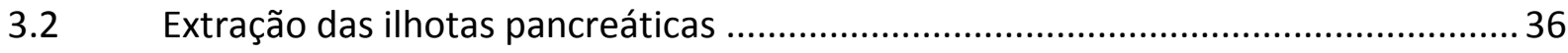

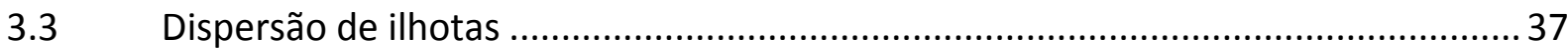

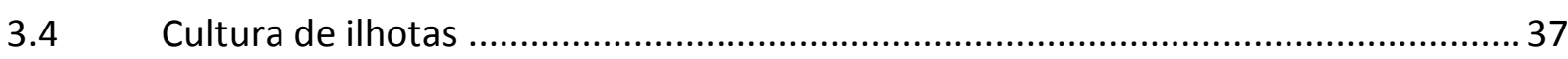

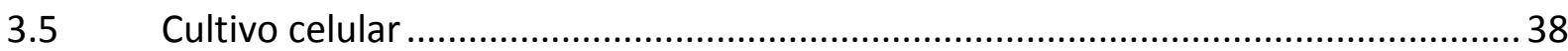

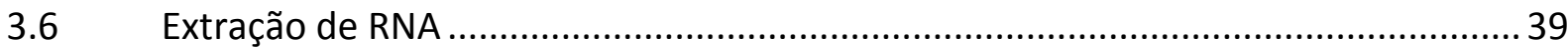

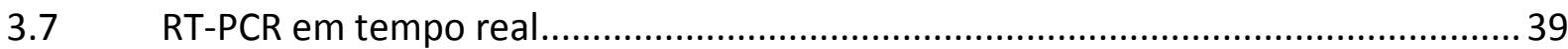

3.8 Análise protéica por Immunoblotting ................................................................ 41

3.9 Estudos de imuno-histoquímica e microscopia de fluorescência ............................. 42

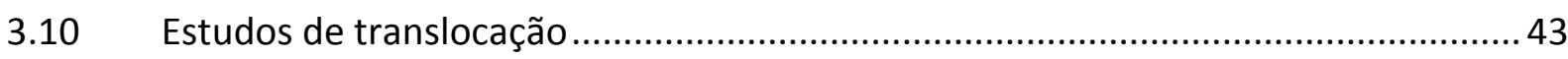

3.11 Avaliação do conteúdo de superóxido citosólico por DHE e mitocondrial pelo

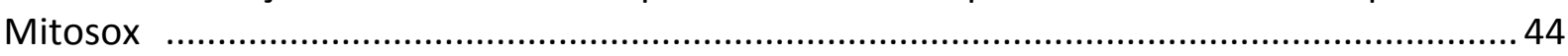

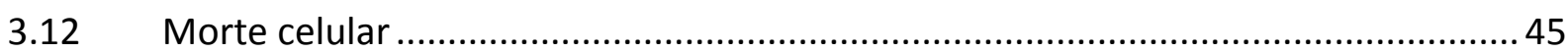

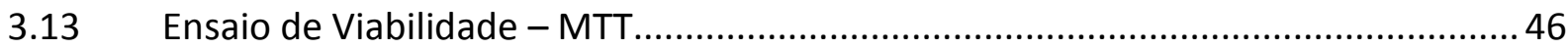

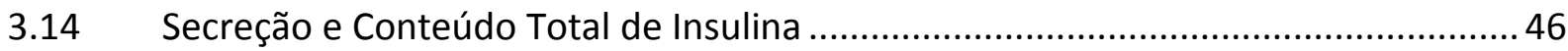

3.15 Quantificação da glutationa reduzida ................................................................ 47

3.16 Análise da formação de redoxossomas ............................................................... 48

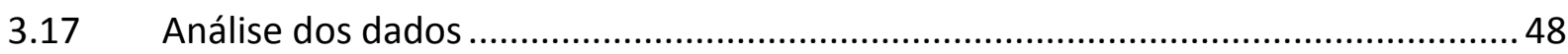

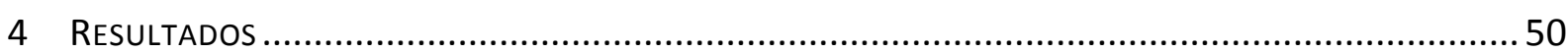

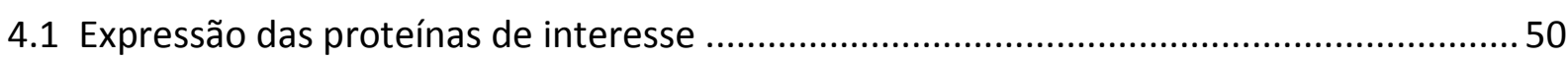

4.1 Conteúdo de superóxido em resposta à glicose .................................................... 52

4.2 Conteúdo mitocondrial de superóxido em resposta à glicose..................................55

4.3 Capacidade de redução da glutationa em resposta à glicose .................................. 56

4.4 Conteúdo de RNAm e proteína das enzimas antioxidantes e componentes da

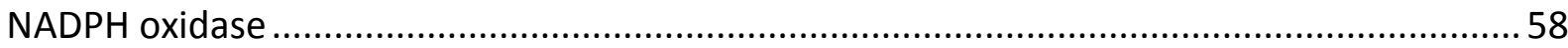

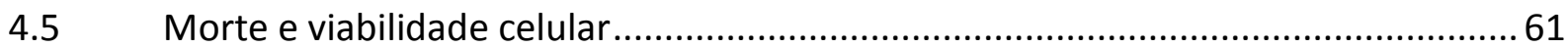

4.6 Secreção de insulina estimulada por glicose com inibição da Sod1 ........................62

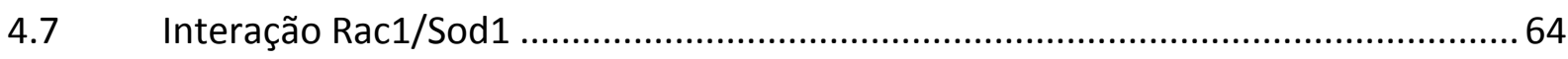

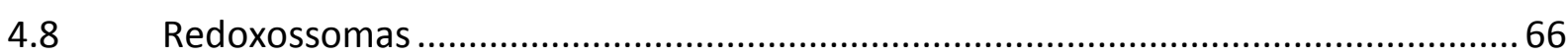

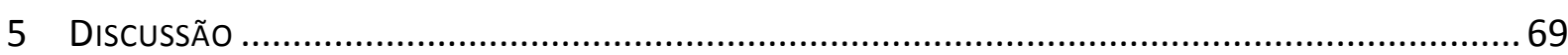

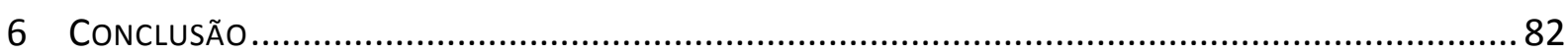

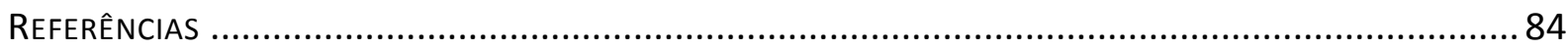

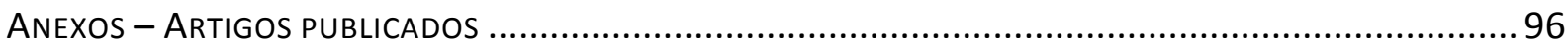




\section{INTRODUÇÃo}

O mundo já foi muito diferente do que é atualmente. Não somente existiram inúmeros animais e plantas que foram extintos ao longo dos milhares de anos da evolução, mas também o cenário da vida já foi bem diverso. Uma das mudanças principais se deu bem antes de existirem organismos multicelulares complexos, tal como conhecemos hoje. $\mathrm{O}$ que mudou, apesar de extremamente importante, muitas vezes passa despercebido: o ar atmosférico. Hoje sua constituição é de $78 \%$ v/v de nitrogênio $\left(N_{2}\right), 21 \%$ de oxigênio $\left(O_{2}\right)$ e apenas $0,04 \%$ de dióxido de carbono $\left(\mathrm{CO}_{2}\right)$, mas há um bilhão de anos atrás praticamente não havia oxigênio na atmosfera, que provavelmente se tratava de um ambiente redutor (KUTSCHERA; NIKLAS, 2013).

A vida surge então a partir de organismos unicelulares e durante um longo período só existiam pequenos organismos procariontes anaeróbios. Mais alguns milhares de anos e surgiram microrganismos semelhantes às cianobactérias, que liberavam oxigênio como produto da fotossíntese. As amostras de rochas deste período contendo óxido de ferro são evidências de que lentamente o ambiente redutor da atmosfera foi se tornando oxidante. Essa mudança ocorreu há cerca de 1,8 bilhões de anos atrás com o surgimento das algas eucarióticas que povoaram e oxigenaram os mares e, subsequentemente, a atmosfera (Figura 1). Com esta mudança ambiental houve uma enorme extinção dos organismos procariontes anaeróbios obrigatórios e uma expansão abrupta dos eucariontes aeróbios (KUTSCHERA; NIKLAS, 2013).

O aparecimento de praticamente todos os filos de animais, há cerca de 500 milhões de anos, é um enigma que claramente está ligado à oxigenação dos oceanos. Uma teoria recente aponta que durante a chamada "explosão do cambriano", período de menos de 30 milhões de anos em que ocorreu o aparecimento de praticamente todos os tipos de planos corporais, a alta oxigenação deu suporte a cadeias alimentares mais complexas. A falta de oxigênio é ligada à baixa proporção de poliquetas carnívoros em sedimentos profundos marinhos, o que é revertido com o aumento do mesmo. Acredita-se então que o oxigênio foi o componente ambiental disparador e a maior variedade de carnívoros foi o componente ecológico direcionador, que atuando juntos permitiram a radiação de organismos do Cambriano (SPERLING et al., 2013). 


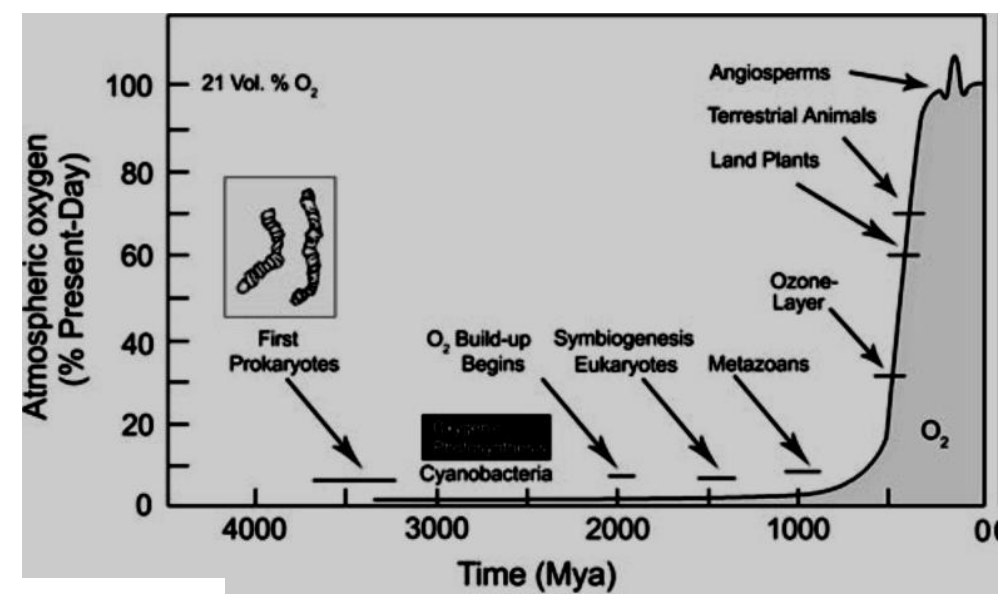

FIGURA 1 - Mudanças na concentração de oxigênio atmosférico nos últimos 3,5 milhões de anos. Ordem de aparecimento dos eventos chave na história da vida: Primeiros procariotos, início da síntese de $\mathrm{O}_{2}$, simbiogênese dos eucariotos, aparecimento dos metazoários, camada de ozônio, plantas terrestres, animais terrestres e angiospermas. Oxigênio atmosférico fornecido em \% em relação aos dias atuais. Fonte: Kutschera e Niklas, 2013.

Outro ponto interessante sobre a dependência biológica do oxigênio é que sem ele provavelmente a vida não teria abandonado o meio aquático e claro, não ocorreriam todas as consequências evolutivas deste evento tão relevante na história natural. Foi o excesso de $\mathrm{O}_{2}$ que gerou a camada de ozônio $\left(\mathrm{O}_{3}\right)$, que protege a atmosfera contra a radiação ultravioleta mutagênica, e assim possibilitou a colonização do ambiente terrestre pelas primeiras plantas há cerca de 430 milhões de anos atrás. A evolução dos organismos multicelulares eucarióticos aquáticos continuou com a crescente quantidade de oxigênio na atmosfera e cinquenta milhões de anos depois apareceram os primeiros animais terrestres. Assim, o surgimento da fotossíntese oxigênica mudou drasticamente o ecossistema terrestre e permitiu o desenvolvimento de organismos multicelulares complexos (KUTSCHERA; NIKLAS, 2013).

Mas, afinal, qual foi a grande vantagem evolutiva conferida pelo oxigênio? Esta resposta está diretamente ligada ao surgimento de um processo bioquímico de obtenção de energia mais eficiente, que é dependente de oxigênio. Ainda no ambiente aquático e anaeróbio toda fonte de energia era derivada da glicólise, processo que gera pouca energia e é independente de oxigênio. O desenvolvimento da fosforilação oxidativa, que produz muito mais moléculas de adenosina trifosfato (ATP) a partir dos nutrientes ingeridos (açúcares, lipídios e aminoácidos), permitiu o surgimento de organismos multicelulares cada vez 
maiores, mais complexos e diferentes. Por isso esse processo ainda é altamente conservado entre os diversos tipos de seres vivos (ALBERTS et al., 2002).

O ATP é a "moeda" de energia dos organismos vivos, a molécula que armazena a energia dos nutrientes ingeridos ou da luz, no caso dos fotossintetizantes. Ela é usada numa miríade de reações das diversas funções biológicas e, portanto, para a manutenção da vida. E já que esta depende de organização, o que requer energia, ela é retirada do ambiente externo seja de fótons ou de compostos orgânicos. Comparando com a glicólise sozinha, que através da fosforilação pelo substrato produz quatro moléculas de ATP a partir de uma molécula de glicose, a glicólise seguida da fosforilação oxidativa é muito mais eficiente, pois juntas geram cerca de trinta e oito moléculas de ATP (MARZZOCO; TORRES, 1999).

Seguindo esta linha de raciocínio eis que surge uma nova pergunta: qual a participação do oxigênio no processo celular de obtenção de energia? O que ocorre de fato é uma oxidação dos combustíveis metabólicos para obtenção de energia. A oxidação, na realidade, resulta na liberação de energia livre em que parte é estocada na forma de ligações fosfoanidras de alta energia na molécula de ATP. Carboidratos, proteínas ou lipídios são substâncias orgânicas oxidáveis que ao perderem prótons e elétrons, liberam energia e no fim tem seus átomos de carbono reduzidos a dióxido de carbono (BONORA et al., 2012). Para exemplificar esse longo processo bioquímico, vamos resumir os passos que levam a glicose a produzir ATP, já que ela é o nutriente mais comum a fornecer energia, apesar de outros também realizarem o mesmo papel, como explicado anteriormente.

No citoplasma, a molécula de glicose é alterada em várias reações enzimáticas em cadeia que no fim geram duas moléculas de ATP (fosforilação pelo substrato) e duas de NADH, um agente redutor, que posteriormente poderá ser convertido também em ATP. A sequência dessas reações é chamada de glicólise. No fim da glicólise a molécula de glicose se transformou em duas moléculas de piruvato (BONORA et al., 2012). Na ausência de oxigênio, a obtenção de energia para por aqui, já que o processo subsequente necessita do mesmo. Porém, na presença de oxigênio mais reações se seguem e a molécula de glicose pode ser completamente oxidada a duas moléculas de $\mathrm{CO}_{2}$, produto de nossa respiração. $\mathrm{O}$ ciclo de reações enzimáticas que se seguem é conhecido por ciclo de Krebs, ou ciclo do ácido cítrico. O piruvato proveniente da metabolização da glicose adentra a mitocôndria e sua 
oxidação gera mais agentes redutores, NADH e FADH. Essa ainda é só uma preparação para a fosforilação oxidativa propriamente dita (MARZZOCO; TORRES, 1999).

Os agentes redutores são os doadores dos elétrons que serão transferidos para a cadeia respiratória. Esta se constitui por uma sequência de quatro complexos, que se encontram na membrana interna mitocondrial, e são fundamentalmente constituídos por proteínas capazes de transportar elétrons. A cadeia é organizada pelo potencial crescente de óxido-redução de seus membros (DIKALOV, 2011). O primeiro componente é o que tem o menor potencial óxido-redutor e o último, que é o oxigênio, o maior. Assim, à medida que os elétrons são transportados pelas proteínas transportadoras, eles vão sendo "roubados" pelo próximo componente da cadeia. Cada transferência acarreta perda de energia livre, que no caso dos complexos culmina com o transporte de $\mathrm{H}^{+}$para o espaço intermembranas, o que gera um gradiente eletroquímico entre o lúmen mitocondrial e o espaço intermembranas. Este gradiente é a força motriz para a síntese de ATP catalisado pela ATP sintase. O aceptor final dos elétrons na cadeia é o oxigênio, que é reduzido à $\mathrm{H}_{2} \mathrm{O}$ como produto final (DIKALOV, 2011; BONORA et al., 2012).

Na verdade, sem oxigênio os agentes redutores não podem ser reoxidados. A função do ciclo de Krebs é basicamente de reciclar o NAD e FAD que doaram seus elétrons à cadeia transportadora, reduzindo-os com elétrons provenientes da molécula de glicose metabolizada. Deste modo, o sistema de obtenção de energia tem uma necessidade ininterrupta por $\mathrm{O}_{2}$, o que torna os mamíferos e a maioria dos seres vivos de grande porte aeróbios estritos. Alguns dos venenos letais mais conhecidos, como o cianeto de potássio ou de sódio, têm sua ação através do bloqueio da cadeia transportadora de elétrons (MARZZOCO; TORRES, 1999).

Após tantos milhares de anos, com o desenvolvimento dos diferentes ramos filogenéticos, houve modificações bioquímicas e estruturais entre as diferentes espécies de organismos multicelulares complexos. Diversas espécies ocuparam os nichos ecológicos disponíveis, inclusive retornando à água. O ancestral dos mamíferos marinhos, como a baleia, era terrestre. Uma foca da Groelândia, por exemplo, é capaz de permanecer duas horas submersa no mar sem respirar. Um ser humano não é capaz de sobreviver alguns minutos sem oxigênio. A diferença reside especialmente no tipo de mioglobina que estes animais possuem. A mioglobina é a proteína responsável pelo transporte e armazenamento 
de oxigênio para os músculos, que no caso dos mamíferos aquáticos possui muito mais afinidade pelo oxigênio, é muito mais estável e é capaz de armazenar maior quantidade desta espécie química do que a proteína dos mamíferos terrestres (MIRCETA et al., 2013).

Entretanto, mesmo com diferenças, todos os organismos complexos ainda são dependentes de oxigênio e o processo de obtenção de energia ainda é fundamentado nas mesmas reações bioquímicas básicas já descritas anteriormente, que ocorrem ubiquamente para obtenção de energia. Por mais que a dependência de oxigênio seja amplamente conhecida atualmente pela população, foi somente no século XVII que o médico John Mayown, percebeu que camundongos morriam em uma gaiola de vidro, sem fluxo de ar (KUTSCHERA; NIKLAS, 2013). Toda a fisiologia da respiração desde o transporte de gases até os processos moleculares da troca de gases, e especialmente a bioquímica relacionada ao oxigênio e seus derivados são descobertas bastante recentes. Afinal, apenas no século XX que o gigante desenvolvimento científico-tecnológico se deu e o número de descobertas têm se acumulado desde então exponencialmente.

Devido a nossa dependência vital do oxigênio, o ar atmosférico foi cunhado como "sopro da vida" ou "gás vital" pelo famoso químico francês Lavoisier, que foi um dos químicos que descobriu o elemento no século XVII (AUGUSTO, 2006; FRIDOVICH, 2013). Alfred Wallace, famoso biólogo que criou a teoria da evolução paralelamente a Darwin, publicou no início do século XX que o oxigênio, junto com o carbono, nitrogênio e hidrogênio, seriam a base da vida (KUTSCHERA; NIKLAS, 2013). Ele, de fato, estava certo. Estes são os átomos mais presentes em seres vivos. Entretanto, ainda há outro lado da história. O uso do oxigênio também tem seu preço. Na década de 1950, Gerschman e colaboradores descobriram um fenômeno interessante, a que eles chamaram de envenenamento pelo oxigênio. Plantas ou animais colocados em um ambiente com oxigênio puro (99\%) apresentavam rapidamente dano tissular e acabavam morrendo. Mais do que isso, esses autores percebiam que mesmo na atmosfera comum o oxigênio pode ser destrutivo para as células (GERSCHMAN et al., 1954).

Mas como explicar este paradoxo? Como um componente vital pode ser ao mesmo tempo letal? O oxigênio é uma espécie química com características bastante peculiares, que de certa forma também são responsáveis pelo seu uso no passo final da respiração celular. 0 átomo de oxigênio $(0)$ possui oito elétrons, seis deles na camada de valência, sendo dois 
desses elétrons desemparelhados, com spins paralelos, ou seja, ocupando orbitais diferentes (Figura 2). Se ocupassem o mesmo orbital estes elétrons teriam direção de spin opostas e assim o campo magnético criado por cada um deles se anulariam entre si. Como não é o caso, o oxigênio é uma espécie química paramagnética. Se fosse sólido, assim como o ferro, seria capaz de ser atraído para magnetos (FRIDOVICH, 2013).

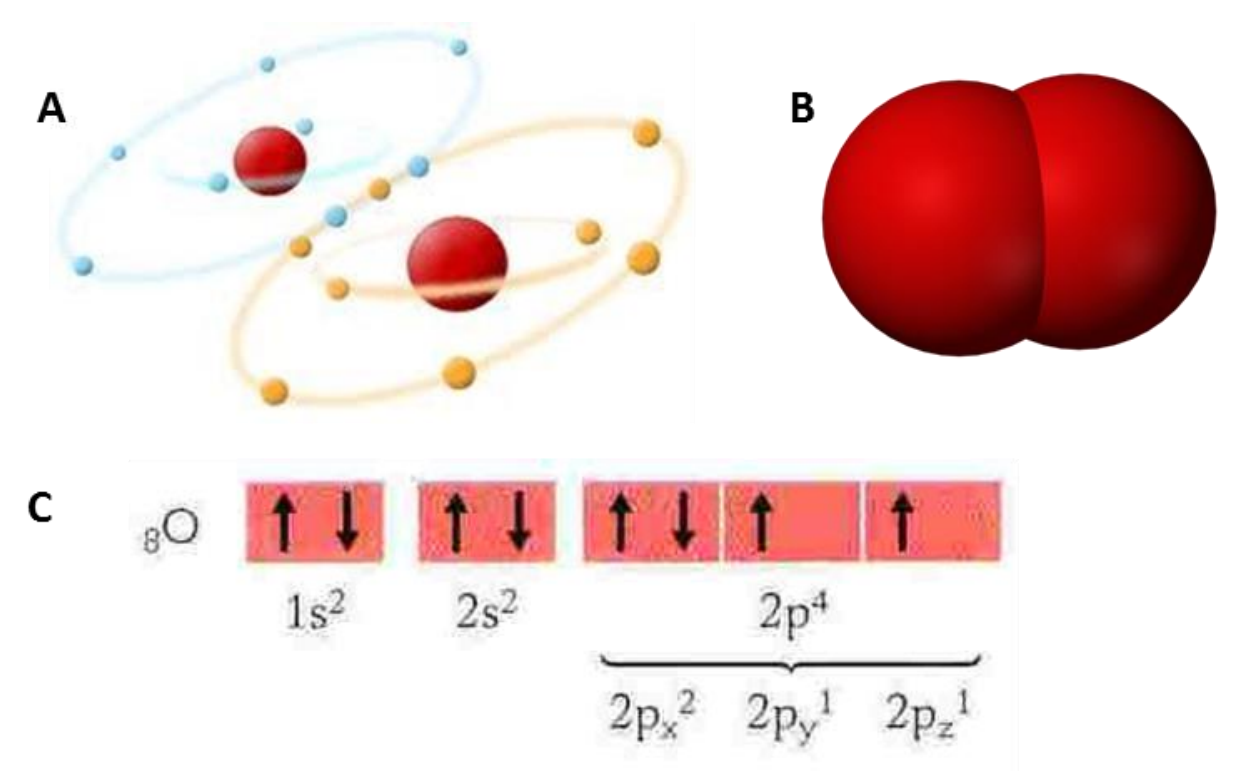

FIGURA 2: Representações químicas do oxigênio molecular $\left(\mathrm{O}_{2}\right)$. A) Compartilhamento de elétrons pelos dois átomos de O; B) Representação do átomo de oxigênio; $\mathbf{C}$ ) Configuração eletrônica das camadas de valência do $\mathrm{O}_{2}$, mostrando seus dois elétrons desemparelhados de mesmo spin. Fonte: Sítios na internet - http://www.reidaverdade.net/atomo-carbono-neutro-oxigenioimagens.html e http://quipronat.wordpress.com/2010/10/13/o2/ acessados em 24/10/2013.

Além disso, espécies químicas com elétrons desemparelhados, chamadas de radicais livres, podem ser muito mais reativas, pois tendem a reagir com outros elementos químicos para adquirir uma configuração mais estável. Mas há exceções como o oxigênio presente no ar atmosférico. $\mathrm{O}$ oxigênio que respiramos está em sua forma diatômica $\left(\mathrm{O}_{2}\right)$, que não é a forma mais reativa deste composto. Apesar de ser um radical livre, o $\mathrm{O}_{2}$ é a forma basal, ou mais estável do oxigênio. Ainda assim, devido a sua alta eletronegatividade ainda pode captar elétrons de outras moléculas. Isto é o que ocorre quando o complexo IV da cadeia 
respiratória doa elétrons para o oxigênio, formando então $\mathrm{H}_{2} \mathrm{O}$ (HALLIWELL; GUTTERIDGE, 1999).

Porém nos organismos vivos não encontramos apenas o $\mathrm{O}_{2}$. Há inúmeros derivados do $\mathrm{O}_{2}$ que são coletivamente chamados de espécies reativas de oxigênio (EROs). O nome se relaciona à facilidade de reagir destes compostos. As EROs tanto podem ser radicais livres ou não, como é o caso do peróxido de hidrogênio $\left(\mathrm{H}_{2} \mathrm{O}_{2}\right)$. Porém, todos os radicais livres são espécies reativas (HALLIWELL; GUTTERIDGE, 1999). Pra estes casos temos muitos exemplos. Alguns deles o radical ânion superóxido $\left(\mathrm{O}_{2}{ }^{\circ}\right)$, oriundo da adição de um elétron ao $\mathrm{O}_{2}$, o óxido nítrico $\left(\mathrm{NO}^{\circ}\right)$ e o radical hidroxil $\left(\mathrm{OH}^{\circ}\right)$. Este último, por ser altamente oxidativo, é a mais danosa das EROs (BARTOSZ, 2009). A produção das EROs em sistemas biológicos provém de reações redox (de redução e oxidação), como as que ocorrem na cadeia de transporte de elétrons (AUGUSTO, 2006).

A ação deletéria do oxigênio é oriunda das EROs. Ela se dá porque, ao reagir facilmente, eles podem gerar alterações químicas em componentes celulares como proteínas, ácidos nucleicos e lipídios. Estas alterações em muitos casos levam a perda de função de enzimas e elementos estruturais, imprescindíveis para o bom funcionamento celular. Além disso, reações radicalares normalmente se dão em cadeia, pois a molécula não radicalar que é oxidada e perde elétrons se transforma em um radical e tende a reagir novamente, o que propaga o dano (HALLIWELL; GUTTERIDGE, 1999). Classicamente são conhecidas como marcadores moleculares da ação danosa de EROs o 4-hidroxinonenal que indica alterações em lipídios, o 8-hidroxi-4-desoxiguanosina marcador das modificações no DNA e, por fim, a nitrotirosina que indica alterações neste resíduo de aminoácido das proteínas (KALYANARAMAN, 2013).

Para contrapor a ação deletéria que o oxigênio e seus subprodutos podem gerar, ao longo da evolução foi selecionada e desenvolvida uma miríade de mecanismos antioxidantes nas células, que também é ubíqua tanto entre os organismos quanto a nível celular. Com essa função se adéquam as moléculas com função "tamponante", como o tripeptídeo glutationa, e as enzimas que catalisam a conversão das EROs em compostos químicos menos reativos, como a catalase, peroxirredoxinas e até sensores redox que regulam a transcrição de conjuntos de genes antioxidantes (FRIDOVICH, 2013). 
Dentre as enzimas antioxidantes, temos uma família de proteínas responsáveis pela dismutação do $\mathrm{O}_{2}{ }^{\bullet-}$ a $\mathrm{H}_{2} \mathrm{O}_{2}$. A primeira a ser descoberta, a superóxido dismutase Cobre/Zinco ou Sod1, é uma enzima altamente conservada, distribuída no citoplasma de todas as células dos organismos eucariotos. Está presente também no núcleo e no espaço intermembranas da mitocôndria. Além dela, também temos a manganês Sod, ou Sod2, presente na mitocôndria e a Sod3 ou Sod extracelular. Para ilustrar a importância dessas enzimas, a deleção de Sod2 é letal para os camundongos knockout (JUAREZ et al., 2008).

Quando a Sod1 foi identificada a nomearam inicialmente de eritrocupreína, por ser conhecida como a maior proteína contendo cobre nos eritrócitos. Acreditava-se que sua função era apenas de armazenamento de cobre. Sua atividade catalítica só foi descoberta em 1969, quando McCord e Fridovich perceberam que ela não só era capaz de catalisar a dismutação do radical $\mathrm{O}_{2}{ }^{\circ-}$, como era amplamente distribuída nos tecidos de mamíferos (MCCORD; FRIDOVICH, 1969). A reação global envolve dois $\mathrm{O}_{2}{ }^{\circ-}$, sendo um oxidado a oxigênio molecular e outro reduzido e reunido a dois átomos de hidrogênio formando $\mathrm{H}_{2} \mathrm{O}_{2}$. (Figura 3) O cobre está no centro catalítico da enzima e é responsável pela transferência dos elétrons, alternando entre o estado $\mathrm{Cu}^{+}$e $\mathrm{Cu}^{2+}$ (RAKHIT; CHAKRABARTTY, 2006).

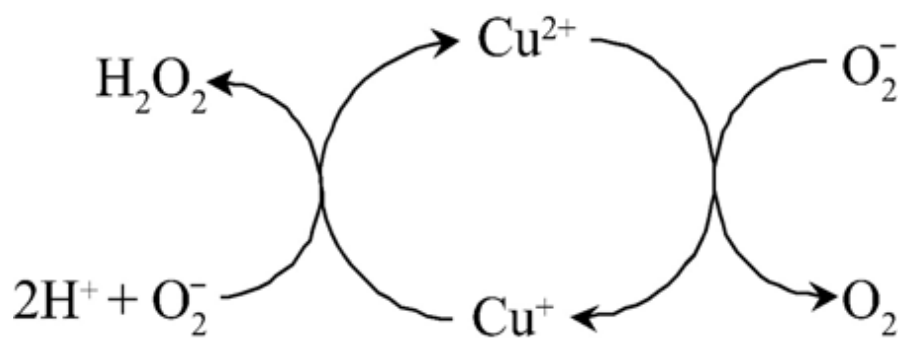

FIGURA 3: Reação global da enzima Sod1. A dismutação do superóxido a peróxido de hidrogênio catalisada pela superóxido dismutase 1 é feita em dois passos e envolve a transição do cobre no centro catalítico entre os estados cúprico e cuproso. Fonte: Rakhit e Chakrabartty, 2006.

A Sod1 de mamíferos é formada por dois dímeros, ligados por interações hidrofóbicas. Esta dimerização permite grande estabilidade da proteína e acredita-se que possa estar relacionada à função cooperativa entre as duas subunidades. Cada uma delas possui um átomo de cobre e outro de zinco, com funções estruturais e catalíticas. A enzima sofre ao menos quatro modificações pós-traducionais: inserção de zinco, inserção de cobre, 
dimerização e formação da ponte dissulfídica. Estes processos não estão totalmente esclarecidos, mas envolvem a provável ação de outras proteínas como chaperonas, metalotioneínas e a CCS, ou chaperona de cobre para Sod1 (RAKHIT; CHAKRABARTTY, 2006).

Sem estas alterações, a Sod1 se torna inativa, pois elas são necessárias para manter sua estrutura e estabilidade. Mutações que afetem este processo, sejam na própria Sod1 ou em proteínas envolvidas, podem inativar a enzima e assim ocasionar doenças neurodegenerativas como a esclerose lateral amiotrófica ou ELA (RAKHIT; CHAKRABARTTY, 2006). Mutações nas Sods, ou alterações em sua expressão e/ou atividade também estão associadas a diferentes doenças como tumores, doença cardiovascular, depressão, esquizofrenia, doença de Huntigton, Parkinson, Alzheimer e Síndrome de Down (D'ALESSANDRO; ZOLLA, 2011).

O mais curioso é pensar que apesar do oxigênio e de suas espécies reativas apresentarem potenciais danos para nosso organismo e que mesmo havendo um sistema antioxidante protetor, eles são produzidos também através de diversas maneiras nas células. $\mathrm{O} \mathrm{O}_{2}{ }^{\bullet-}$ é a principal ERO produzida nos sistemas biológicos e a cadeia de transporte de elétrons é a principal fonte do mesmo (BARTOSZ, 2009). Essa produção classicamente foi considerada um erro, apenas um subproduto do metabolismo oxidativo, mas essa visão tem sido questionada; é bastante plausível que a produção de EROs mitocondriais tenha funções fisiológicas relevantes (DIKALOV, 2011).

O oxigênio por ser uma espécie paramagnética, ou seja, possuir dois elétrons desemparelhados que estão em orbitais diferentes e possuem o mesmo spin, só pode receber um elétron por vez. Só seriam adicionados dois elétrons se outra espécie química fosse paramagnética e com spins paralelos e opostos aos do oxigênio. Porém, isto é muito raro, pois a maioria das moléculas estáveis não é paramagnética. Isso cria a chamada restrição pelo spin do oxigênio e deste modo, a sua redução na cadeia de transporte mitocondrial é feita por uma via univalente. Isso quer dizer que até a redução ser completa haverá quatro adições de elétrons, um por vez, gerando assim intermediários (FRIDOVICH, 2013). Os intermediários formados em sequencia são: $\mathrm{O}_{2}{ }^{\circ-}, \mathrm{H}_{2} \mathrm{O}_{2}$ e $\mathrm{OH}^{\bullet}$. O escape de $\mathrm{O}_{2}{ }^{\circ-}$ pode ocorrer em vários pontos na cadeia de transporte, sendo os principais pontos os complexos I e II (Figura 4). O transporte reverso entre estes complexos é a maior fonte de EROs da mitocôndria, apesar do complexo III também poder gerar $\mathrm{O}_{2}{ }^{--}$(DIKALOV, 2011). 
A outra grande fonte de $\mathrm{O}_{2}{ }^{\circ-}$ é a NADPH oxidase, um complexo enzimático formado por várias proteínas. Inicialmente descrita em fagócitos, é responsável pelo burst oxidativo usado contra microrganismos patogênicos pelo sistema imune. Porém, hoje sabemos que a NADPH oxidase é ubiquamente expressa nos diferentes tecidos, ocorrendo em células de origem mesodermal (BABIOR, 1999). Além disso, também é amplamente distribuída nos diversos reinos biológicos, estando ausente em procariotos e na maioria dos eucariotos unicelulares, mas presentes em fungos, plantas e animais (BEDARD et al., 2007).

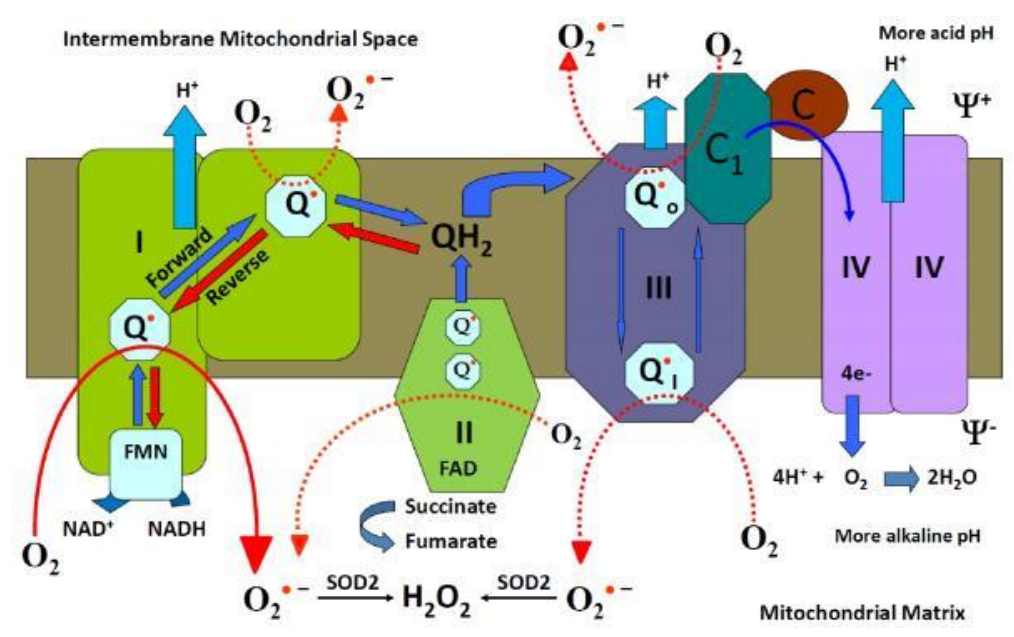

\section{FIGURA 4 - Representação esquemática da cadeia mitocondrial de transporte de elétrons. A produção de superóxido se dá principalmente nos Complexos I e II. Fonte: Dikalov, 2011.}

Este complexo enzimático é composto por várias subunidades, sendo algumas delas proteínas integrais de membrana e outras proteínas citoplasmáticas (Figura 5). As subunidades que ficam na membrana são gp91 ${ }^{\text {phox }}$ e $p 22^{\text {phox }}$, que juntas são chamadas de flavocitocromo b558. A abreviação gp é de glicoproteína, enquanto p vem de proteína, o número é referente ao peso molecular da subunidade e phox vem de phagocyte oxidase (NAUSEEF, 2008). A subunidade gp9 $1^{\text {phox }}$ se colocaliza na membrana plasmática com a proteína transmembrânica p22 $2^{\text {phox }}$. A associação entre elas se dá na proporção $1: 1$, e é necessária para a atividade da enzima, pois apenas a união das duas subunidades gera um complexo estável para a ancoragem dos outros componentes da enzima e para a produção de superóxido (MIYANO; SUMIMOTO, 2007). Além disso, em células mieloides, é necessária 
a coexpressão das duas subunidades para o egresso do retículo endoplasmático (RE) até a membrana plasmática. A expressão de apenas uma delas ocasiona o aprisionamento no RE e posterior degradação (DELEO et al., 2000).
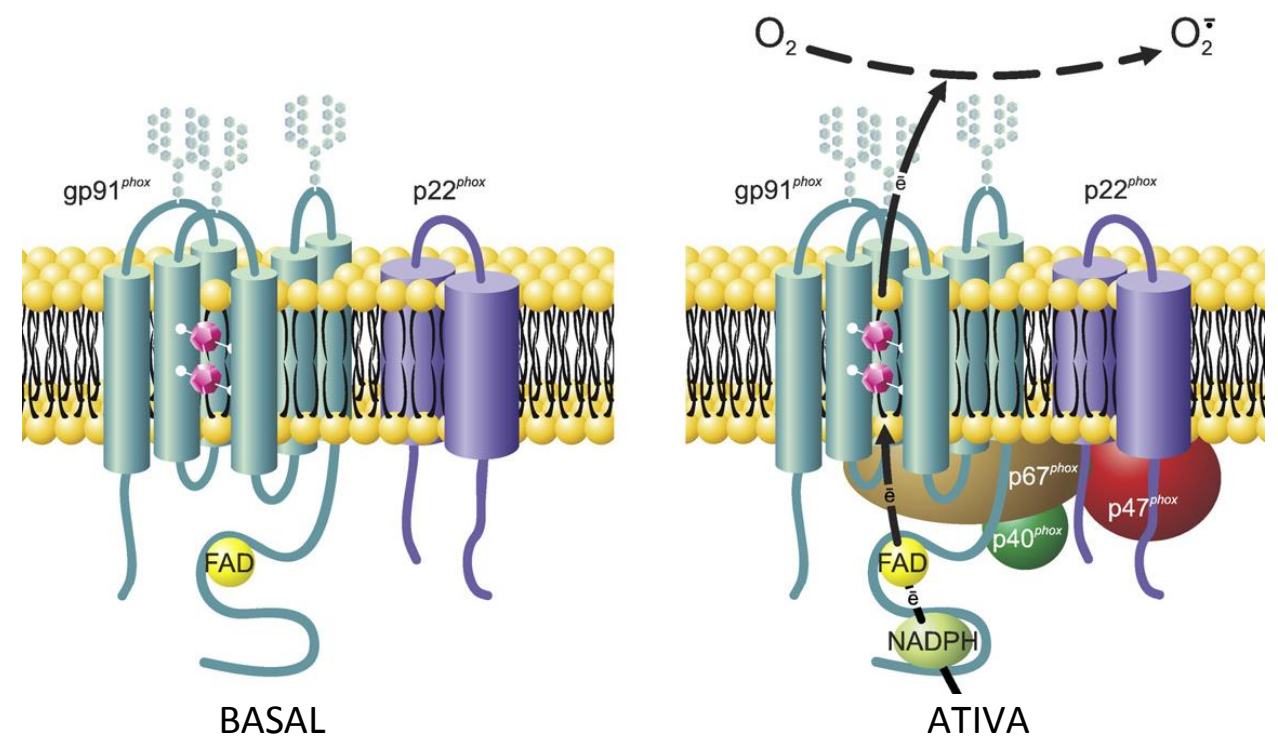

FIGURA 5 - Estrutura do complexo enzimático NADPH oxidase em seu estado basal e ativado. Está apresentada em detalhes a estrutura tridimensional proposta para gp $91^{\text {phox }}$ e $\mathrm{p} 22^{\text {phox }}$, proteínas integrais de membrana. A primeira possui seis alfahélices, dois grupos heme distintos (círculos fúcsia), domínios de ligação citoplasmáticos para o NADPH e FAD e pontos de glicosilação nos loops extracelulares, enquanto a segunda possui apenas dois domínios alfa-hélice transmembrana. Também são mostradas as subunidades citoplasmáticas $\mathrm{p} 67^{\text {phox }}, \mathrm{p} 47^{\text {phox }}$ e p $40^{\text {phox }}$, que migram para a membrana quando a enzima está ativa. Fonte: Nauseef, 2014.

Os componentes citoplasmáticos formam dois complexos. No estado basal as subunidades $\mathrm{p} 67^{\text {phox }}, \mathrm{p} 47^{\text {phox }}$ e $\mathrm{p} 40^{\text {phox }}$, se mantém unidas em trímeros em complexos de 240-260 KDa. Elas possuem em sua estrutura diversos domínios para interação com outras proteínas e com fosfolipídios de membrana. A subunidade $\mathrm{p} 47^{\text {phox }}$ é chamada de organizadora por não possuir atividade catalítica, mas por criar condições para que a subunidade ativadora, $p 67^{\text {phox }}$, regule a redução do FAD pelo NADPH, no centro catalítico, gp91phox (HAN; LEE, 2000; CHENG et al., 2004). O outro complexo citosólico é formado por uma pequena proteína G, um dos subtipos de Rac (Ras-related C3 botulinum toxin substrate), mais RhoGDI. Esta última proteína é inibidora da dissociação de GDP da Rac, 
quando a mesma se encontra em seu estado inativo. Para células fagocíticas é a Rac2 a participar do complexo, enquanto nas células não-fagocíticas, a Rac1 (DORSEUIL et al., 1996)

A síntese de superóxido só ocorre quando as subunidades citoplasmáticas se ancoram junto às subunidades da membrana. Inúmeros estímulos podem desencadear a produção de $\mathrm{O}_{2}{ }^{\bullet-}$. Dentre eles estão fatores metabólicos, como glicose, ácidos graxos e insulina, fatores inflamatórios como citocinas, fatores de crescimento e fatores ambientais como hipóxia/reoxigenação (KLENIEWSKA et al., 2012). Estes fatores ativam quinases específicas, como a PKC, a MAPK ou a PI3-K que fosforilam p47 $7^{\text {phox }}$ (PONTING, 1996).

Ao fosforilar a subunidade organizadora, domínios de endereçamento à membrana são expostos, o que leva a sua migração junto com $\mathrm{p} 40^{\text {phox }}$ e $\mathrm{p} 67^{\text {phox }}$ para junto de gp91 ${ }^{\text {phox }} \mathrm{e}$ p22 $2^{\text {phox }}$ (PONTING, 1996; YAMAMORI et al., 2000). A Rac também deve ser ativada através da mudança de ligação a uma molécula de GDP por uma de GTP, processo que é auxiliado pelas proteínas chamadas de GEF, ou GDP/GTP Exchange Factor. Essa ligação ao GTP promove uma mudança conformacional na estrutura da Rac que aumenta a afinidade pelas proteínas alvo efetoras das vias de sinalização de que ela participa (HEO; CAMPBELL, 2005).

$\mathrm{O}$ centro catalítico que promove a transferência do elétron do NADPH para o $\mathrm{O}_{2}$ é a subunidade gp91 ${ }^{\text {phox }}$ (GEISZT; LETO, 2004). Esta é formada por seis regiões transmembrana alfa-hélice em sua parte $\mathrm{N}$-terminal, enquanto sua parte $\mathrm{C}$-terminal é citoplasmática e possui os domínios de ligação ao FAD e NADPH, essenciais para sua atividade (HORDIJK, 2006). O domínio de ativação de $p 67^{\text {phox }}$ permite que o grupamento hidrido seja transferido do NADPH para o FAD formando $\mathrm{NADP}^{+}$e $\mathrm{FADH}_{2}$, sem afetar a ligação do NADPH. Além disso, acredita-se que a Rac auxilie neste processo induzindo uma mudança conformacional na p $67^{\text {phox }}$, permitindo que seu domínio de ativação atue em $g p 91^{\text {phox }}$. A Rac por si só também tem ação na ativação da oxidase independente da subunidade ativadora (LAMBETH et al., 2007)

Nas terceira e quinta hélices da proteína estão dois resíduos de histidina que são os prováveis ligantes de ferro dos dois grupos hemes não idênticos presentes na estrutura de gp91 ${ }^{\text {phox }}$, sendo um externo à membrana e outro interno. Deste modo, como eles são perpendiculares à superfície da membrana, dois elétrons são transferidos do NADPH citoplasmático para o FAD e através da membrana pelos grupamentos hemes reduzindo de 
forma sequencial duas moléculas de $\mathrm{O}_{2}$, produzindo então dois radicais $\mathrm{O}_{2}{ }^{\circ}$, como está esquematizado na figura 6 (SUMIMOTO, 2008; NAUSEEF, 2014).
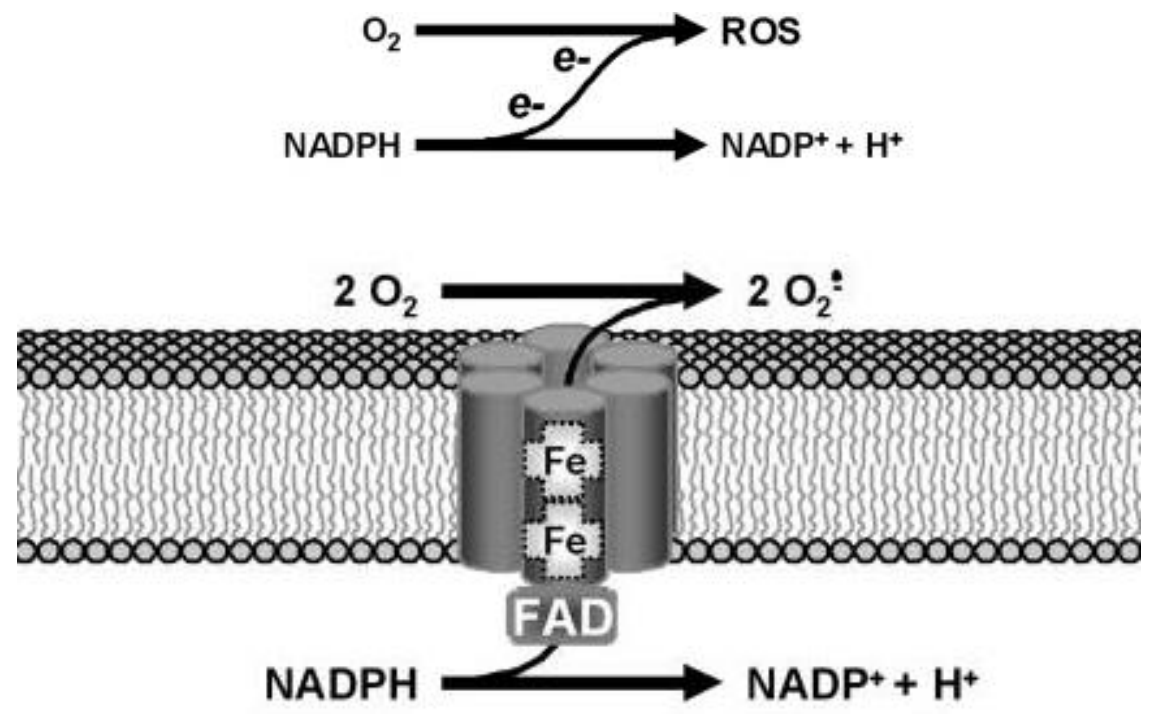

FIGURA 6 - Geração de Espécies reativas de oxigênio pela NADPH oxidase. A transferência de elétrons se dá do NADPH através do grupo FAD que os transfere através dos grupamentos heme embebidos na membrana até $o$ oxigênio molecular formando dois ânions superóxido a cada doador de elétrons. Fonte: Modificado de Leto et. al, 2009.

Com a disponibilização do genoma humano, foi possível encontrar proteínas homólogas ao centro catalítico gp91 ${ }^{\text {phox }}$, que compõem uma família chamada Nox com sete membros (Figura 7). A subunidade gp91 ${ }^{\text {phox }}$ foi redenominada de Nox2. As outras são Nox1, 3, 4 e 5 e DUOX1 e 2, todas homólogas ao Nox2. A Nox1 é encontrada principalmente no cólon, a Nox2 em células fagocíticas do sistema imune, Nox3 no ouvido interno, Nox4 nos rins e células sanguíneas, Nox5 em tecidos linfoides e nos testículos e as Duox na tireoide. Entretanto, elas não são exclusivas desses tecidos sendo também expressas em outros locais (BEDARD; KRAUSE, 2007). Todas Nox produzem $\mathrm{O}_{2}{ }^{\circ-}$, exceto a Nox4 e as Duox que se acredita produzirem $\mathrm{H}_{2} \mathrm{O}_{2}$ (NAUSEEF, 2014).

Considerando o grande número de proteínas da família Nox e de seus componentes acessórios, do fato de eles serem os únicos complexos enzimáticos cuja função exclusiva é produção de EROs, da multiplicidade de papéis atrelados ao $\mathrm{O}_{2}{ }^{\circ-}$, da sua existência tanto no reino animal quanto no vegetal (o que aponta para a sua remota ancestralidade), da coexpressão de proteínas homólogas num mesmo tipo celular e aparente redundância de 
função, podemos inferir a sua imensa importância na homeostase e em como ainda há um grande campo para pesquisa científica relacionada a estes complexos (WINGLER et al., 2011).
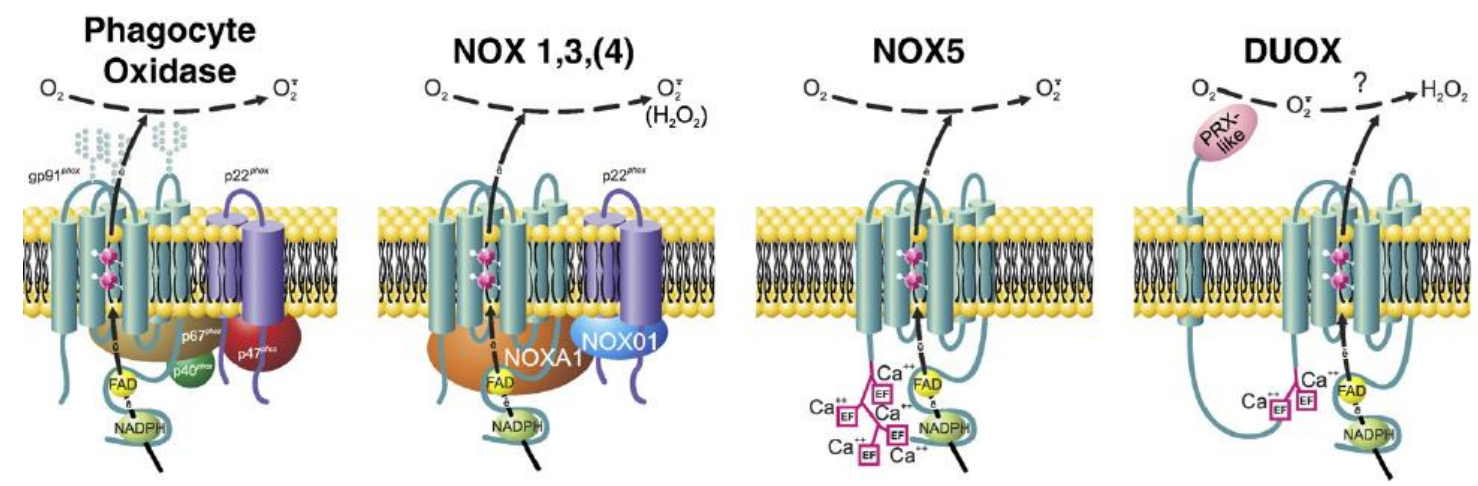

FIGURA 7: A família NADPH oxidase. No estado ativo os membros Nox/Duox variam com relação ao requerimento da associação com p22 ${ }^{\text {phox }}$, da necessidade de co-fatores citosólicos e da regulação por cálcio via domínios EF-Hands. Acredita-se que Duox tenha domínio similar à peroxidase (PRX-like). Fonte: Nauseef, 2014.

Classicamente a Nox2 tem sido citada por inúmeras fontes como participante no desenvolvimento e progressão de muitos processos patofisiológicos, especialmente devido à superprodução de EROs (WINGLER et al., 2011). Assim, contribui diretamente para o estresse oxidativo, reportado como presente em doenças metabólicas como o diabetes, doenças cardiovasculares e doenças neurodegenerativas. O estresse oxidativo é caraterizado pelo excesso de EROs devido a um desbalanço entre a sua produção e a capacidade de eliminação (KALYANARAMAN, 2013). Entretanto, apesar do conceito ser amplamente usado, ele não é claramente definido em termos quantitativos. Dos inúmeros tipos de marcadores utilizados, como produtos de peroxidação lipídica e concentração de antioxidantes em fluidos biológicos, poucos apresentam correlação positiva entre si. Na realidade, é muito difícil que se consiga definir o estresse oxidativo em termos universais (DOTAN et al., 2004).

A mídia explorou muito o assunto, especialmente associando os perigosos radicais livres ao envelhecimento. Antioxidantes como a vitamina $\mathrm{C}$ foram considerados a cura de todos os males, da gripe ao câncer (AUGUSTO, 2006). Porém, os testes farmacológicos com o uso de antioxidantes gerais não foram muito promissores (DICKINSON; CHANG, 2011; WINGLER et al., 2011). A teoria dos radicais livres responsáveis pelo processo de 
envelhecimento vem caindo por terra, pois os danos causados pelo estresse oxidativo ao longo da vida são só uma parte dos muitos erros acumulados pelas imperfeições dos sistemas biológicos (GLADYSHEV, 2014). Artigos recentes apontam que a administração excessiva de antioxidantes podem ter efeitos mais danosos do que benéficos (DOTAN, LICHTENBERG, et al., 2009; DOTAN, PINCHUK, et al., 2009).

$\mathrm{O}$ uso de dois dos antioxidantes mais comuns em estudos científicos, a N-acetilcisteína e vitamina $E$, estimularam o crescimento do tumor de pulmão e diminuíram a sobrevida dos animais (SAYIN et al., 2014). Além disso, os tumores com baixas defesas antioxidantes têm melhores prognósticos, assim como os fármacos que as diminuem obtém melhores resultados. Isso se deve à direta participação das EROs no processo de apoptose, inclusive sendo esta a via de ação de algumas fármacos antitumorais (WATSON, 2013). Ou seja, a razão para o insucesso dos tratamentos com antioxidantes é que o lado mau dos radicais de oxigênio é apenas um dos lados da moeda. Se as espécies reativas são perigosas, elas também são naturais (AUGUSTO, 2006).

O interesse da área biomédica pela química redox foi evidenciado após a década de 1950 por três eventos principais: 1) a descoberta pela argentina Rebeca Gerschman de que as injúrias teciduais causadas pela hiperóxia provinham de radicais livres de oxigênio (GERSCHMAN et al., 1954); 2) a teoria do envelhecimento devido aos radicais livres (HARMAN, 1956); 3) e por fim a descoberta da ação enzimática de Sod1 (MCCORD; FRIDOVICH, 1969). Porém, a importância definitiva das EROs na fisiologia só foi definitivamente cunhada na década de 1980 quando descobriu-se que o óxido nítrico é um sinalizador celular, com uma produção regulada enzimaticamente (pelas NO sintases) e com papel imprescindível como agente relaxante do músculo liso vascular (HANCOCK, 2009).

O entendimento mais profundo da importância desses radicais se deu recentemente com mais um ponto de ruptura no pensamento corrente acerca das EROs em sistemas biológicos. A comunidade científica percebeu que alterações redox, oxidações promovidas por EROs, poderiam atuar como segundos mensageiros, ou seja, ter uma atuação similar ao cálcio, por exemplo (DICKINSON; CHANG, 2011). Estas alterações podem modular a atividade de proteínas através de sua ativação ou inativação.

A espécie reativa de oxigênio mais cotada como sinalizadora é $\mathrm{H}_{2} \mathrm{O}_{2}$ por ser uma molécula pequena, amplamente produzida e bastante difusível. Além disso, possui os 
principais requisitos para ser um bom sinalizador: a) é possível regular sua concentração tanto pela síntese quanto pela sua destruição; b) presença de alvos específicos; c) e a possibilidade de reversão do efeito sinalizador (BARTOSZ, 2009). O principal alvo do peróxido de hidrogênio são os grupamentos tióis dos resíduos de cisteínas presentes nas proteínas. As alterações deflagradas podem ser a formação de pontes dissulfeto ou a criação de um ácido sulfênico, gerando mudança da conformação tridimensional e potencialmente a atividade da proteína (HANCOCK, 2009; DICKINSON; CHANG, 2011)

Hoje há relatos de várias proteínas que são oxidadas pela ação do peróxido de hidrogênio. Dentre elas se encontram membros da via de sinalização da insulina como seu próprio receptor, MAPK, AKT e PTP1B (CORCORAN; COTTER, 2013). Esta ultima fosfatase é uma enzima crucial para a regulação da via de sinalização da insulina, já que sua ação desfosforila as proteínas alvo do hormônio, inativando-as. Porém, a oxidação de um resíduo de cisteína via $\mathrm{H}_{2} \mathrm{O}_{2}$ leva ao bloqueio da ação de PTP1B. Acredita-se que essa é a explicação para resultados que há muito mostravam uma pequena produção de $\mathrm{H}_{2} \mathrm{O}_{2}$ em resposta à insulina e de que oxidantes facilitavam ou mimetizavam sua ação (GOLDSTEIN et al., 2005). Outras vias já bem definidas da participação da sinalização celular é o papel do superóxido na fisiologia endotelial, o envolvimento no controle do ritmo circadiano, a proliferação de células tronco na neurogênese e na atividade do citoesqueleto durante a migração celular (LEE; GRIENDLING, 2008; CORCORAN; COTTER, 2013; KALYANARAMAN, 2013; DIKALOV et al., 2014).

A partir daí percebe-se que a produção endógena de EROs não tem um papel apenas fisiopatológico, mas essencialmente fisiológico. Afinal, se existe uma família de complexos enzimáticos produtores de superóxido ou peróxido de hidrogênio com expressão ubíqua em células, organelas e organismos, como a família Nox/Duox, há de se esperar que estes radicais tenham funções importantes (HANCOCK, 2009). Inicialmente não se achava que as EROs pudessem ser bons sinalizadores, mas os dados recentes na literatura apontam para a direção contrária. Além do NO, espécie que foi pioneira na descrição da sinalização redox e do $\mathrm{H}_{2} \mathrm{O}_{2}$, citado anteriormente, o $\mathrm{HOCl}$ (ácido hipocloroso) também pode ser uma molécula sinalizadora (DICKINSON; CHANG, 2011).

É possível que futuramente se descubra que as alterações redox geradas em proteínas sejam tão importantes como a fosforilação/desfosforilação de enzimas nas vias de 
sinalização. Até então a fosforilação de resíduos de aminoácidos era considerado o principal mecanismo da homeostase celular. Agora, mecanismos análogos têm sido descobertos, como a S-glutationilação (adição reversível de uma glutationa a um resíduo de cisteína), e estes são redox-dependentes (BISWAS et al., 2006). Inclusive algumas dessas alterações são realizadas justamente nas fosfatases e quinases. Assim, percebemos que estes mecanismos regulatórios podem se sobrepor nas vias. Um campo crescente de estudo tem sido o chamado "proteoma redox" que visa avaliar as alterações causada por EROs tanto para avaliar as mudanças reversíveis, modificações pós-traducionais com propósito de sinalização, quanto aquelas irreversíveis, relacionadas à disfunção e ao estresse oxidativo (BUTTERFIELD; DALLE-DONNE, 2014).

Sob esse panorama, o interesse maior atual talvez seja o da homeostase redox, pois não temos apenas o quadro de estresse oxidativo, mas algumas condições apresentam também o chamado estresse redutor. Este é caracterizado pelo excesso de produção de agentes redutores como GSH e NADPH, o que pode gerar modificações indesejáveis em proteínas (WINGLER et al., 2011). Dados também demonstram que não só a superexpressão de Nox4 pode gerar estresse oxidativo em miócitos cardíacos, mas em contrapartida a falta dela é capaz de gerar estresse redutor com piora do quadro de isquemia/reperfusão, com uma contraditória superprodução de EROs mitocondrial. Estes dados indicam como a manutenção do estado redox é um processo complexo e interligado (YU et al., 2014).

Como as reações que envolvem radicais livres costumam ser em cadeia, o que é potencialmente danoso, há a necessidade de uma fina regulação de sua produção e um alto controle do seu alcance. Além disso, muitas delas têm baixa difusibilidade, são extremamente lábeis, além de terem a contrapartida do sistema antioxidante. Deste modo, acredita-se que a sinalização ocorra preponderantemente em microrregiões, onde elas são produzidas e há a colocalização da espécie reativa em questão com o seus alvos (DICKINSON; CHANG, 2011). Está cada vez mais claro que as EROs são geradas próximo às membranas, para o meio extracelular, ou em alguns casos dentro de compartimentos como endossomas, núcleo ou em regiões circunscritas como lipid rafts ou cavéolas (USHIO-FUKAI, 2009; NAUSEEF, 2014). Além do aumento transiente, outro aspecto da sinalização redox é o controle dos tampões e enzimas antioxidantes nestes ambientes, como a inativação das 
peroxirredoxinas I e II para permitir a ação de $\mathrm{H}_{2} \mathrm{O}_{2}$ em proteínas de membrana (WOO et al., 2010).

Além da intrincada regulação espacial da NADPH oxidase, mecanismos acessórios têm sido descritos, como alguns dependentes de $\mathrm{Ca}^{2+}$ e do metabolismo lipídico (BRÉCHARD et al., 2013). Um dos mecanismos mais elegantes de regulação da ação de Nox2 foi descrito por Harraz e colaboradores em 2008. Inicialmente identificado devido ao aumento de produção de EROs em células gliais de animais com esclerose lateral amiotrófica (ELA), este mecanismo ocorre a partir da interação física entre Rac1 e Sod1. A Rac1, ligada ao GTP, estimula a atividade de Nox2, como já dito previamente. Porém, Rac1 tem atividade GTPase intrínseca e rapidamente pode se inativar, hidrolisando o GTP a GDP. O que foi descoberto é que Sod1 ao se ligar a Rac1 faz com que essa permaneça ativa, mantendo a produção de $\mathrm{O}_{2}{ }^{\circ-}$. A parte mais interessante deste mecanismo é que ele é auto regulável, apresentando uma alça de retroalimentação que depende do estado de oxidação do meio, que por sua vez depende da atividade das próprias proteínas envolvidas. Quando o meio está reduzido, a interação Rac1-Sod1 é propícia (Figura 8). À medida que as EROs são produzidas, por ação de Nox2 e também da própria Sod1, o meio se oxida e a interação se desfaz. No caso das Sod1 mutantes, é perdida essa auto regulação (HARRAZ et al., 2008).

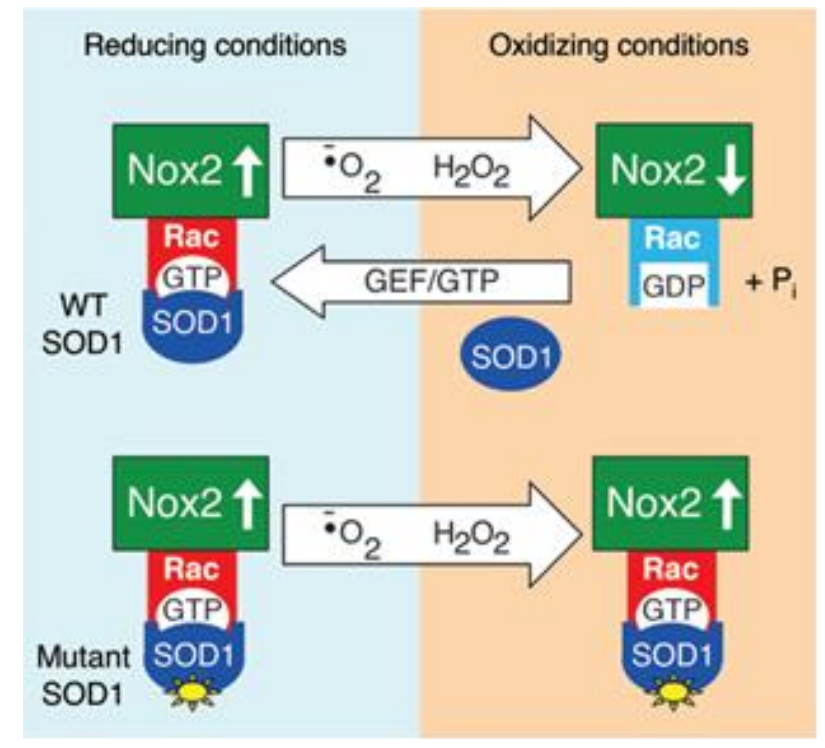

FIGURA 8 - Modelo de sensor redox regulador da produção de superóxido por Nox2 mediado por Sod1 através da sua interação física com Rac1. Abreviaturas: GEF - GDP/GTP exchange factors; GTP - guanosina tri-fosfato; Sod - superóxido dismutase; WT - wild type ou selvagem. FONTE: Harraz et al., 2008 
Além das células gliais, há o relato de que em células endoteliais aórticas tanto a depleção da produção mitocondrial de $\mathrm{O}_{2}{ }^{*-}$ com o uso de antioxidantes quanto a superexpressão de Sod2 levaram à diminuição da atividade citosólica de Nox2. Já a inibição de Sod2 via RNA de interferência teve o efeito oposto, gerando aumento da produção de superóxido. Estes dados apontam também não só para mais vias de regulação da Nox2 através da Superóxido dismutase, mas também pelo crosstalk entre a produção de EROs mitocondrial e via NADPH oxidase (DIKALOVA et al., 2010).

O diabetes é uma doença em que não só a sua fisiopatologia, mas também as comorbidades relacionadas, como a retinopatia, vasculopatia, nefropatia e cardiomiopatia, possuem como fator deletério o estresse oxidativo, com especial destaque para a participação da família Nox (GORIN; BLOCK, 2013). As células beta pancreáticas, responsáveis pela síntese e secreção de insulina, são conhecidas por possuírem uma baixa defesa antioxidante quando comparada a outros tecidos (LENZEN et al., 1996; TIEDGE et al., 1997). Tal fato, pode nos fazer supor que são mais vulneráveis à ação deletéria das EROs. Porém, em 2003 nosso grupo de pesquisa relatou pela primeira vez a presença da NADPH oxidase nestas células (OLIVEIRA et al., 2003). Assim, ainda hoje estamos tentando desvendar os papéis da produção de superóxido via Nox2 nessas células. O que sabemos até agora indica sua participação no processo de secreção da insulina, na sinalização do cálcio e no metabolismo (MORGAN et al., 2009; REBELATO et al., 2011). Porém, os mecanismos moleculares específicos ainda não estão definidos.

O diabetes é dentre os problemas de saúde pública mundial o mais ameaçador. O crescimento de sua incidência, especialmente do diabetes tipo 2, tem sido muito veloz e apesar de atingir mais os países ocidentais, onde o quadro é pior, o aumento já está se expandindo para países mais pobres, inclusive no oriente. Já se fala em uma epidemia global (DANAEl et al., 2011). O crescimento acentuado da doença se relaciona com a mudança do estilo de vida da população nas últimas décadas, que passou a ser mais sedentária e consumir mais gordura, açúcar refinado e produtos processados e industrializados. Intervenções focadas nos hábitos alimentares e exercícios já diminuem bastante o impacto e progressão da doença (SCHELLENBERG et al., 2013).

Ainda assim, estamos diante de um dos maiores desafios da medicina atuais. Há uma corrida para se desenvolver tratamentos mais eficientes contra a disfunção das células 
produtoras de insulina. A fisiologia do pâncreas endócrino é bastante complexa e o diabetes uma doença com origem claramente multifatorial. Atingindo hoje cerca de 347 milhões pessoas no mundo segundo a Organização Mundial de Saúde com previsão de se tornar a sétima causa de morte em 2030 (OMS, 2013).

Partindo do pressuposto de que o estresse oxidativo tenha um papel relevante na disfunção da célula beta pancreática, esse seria um dos pontos de destaque para o desenvolvimento de fármacos para o tratamento do diabetes. Porém, ainda não sabemos com total clareza o papel dos EROs neste tecido endócrino. Além disso, não é claro nem o efeito da glicose, o principal secretagogo da insulina, sobre a homeostasia redox nestas células. Por fim, como já discutido anteriormente, as terapias com antioxidantes gerais não são ideais, sendo provavelmente mais interessantes intervenções pontuais. Assim, também é necessário explorar se há controles adicionais na produção de EROs pela NADPH oxidase e uma possível compartimentalização desta produção no pâncreas endócrino. 


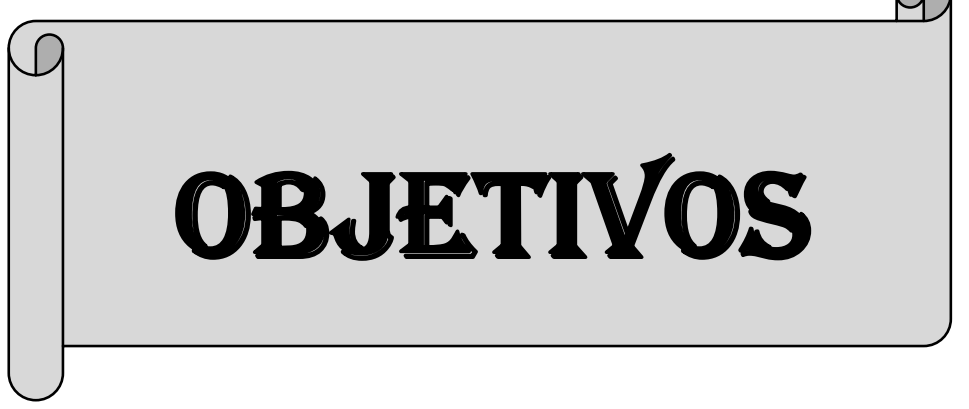




\section{Objetivos}

Nosso objetivo geral foi avaliar se ocorrem alterações na homeostase redox em resposta à mudança da concentração de glicose nas células beta pancreáticas.

Os objetivos específicos foram avaliar em condições de alta e baixa glicose após 1 ou 48 horas de estímulo in vitro se haviam alterações: i) no conteúdo de superóxido citosólico e mitocondrial; ii) na capacidade de redução da glutationa; iii) na expressão das enzimas antioxidantes e constituintes da NADPH oxidase; iv) na morte celular. Além disso, também objetivamos avaliar se este secretagogo da insulina seria capaz de: v) alterar mecanismos adicionais de controle da produção de espécies reativas de oxigênio como a interação Rac1/Sod1, se a inibição da sod1 alteraria a secreção de insulina estimulada por glicose e por último vii) se estimularia a produção de superóxido em endossomas nas células beta pancreáticas. 


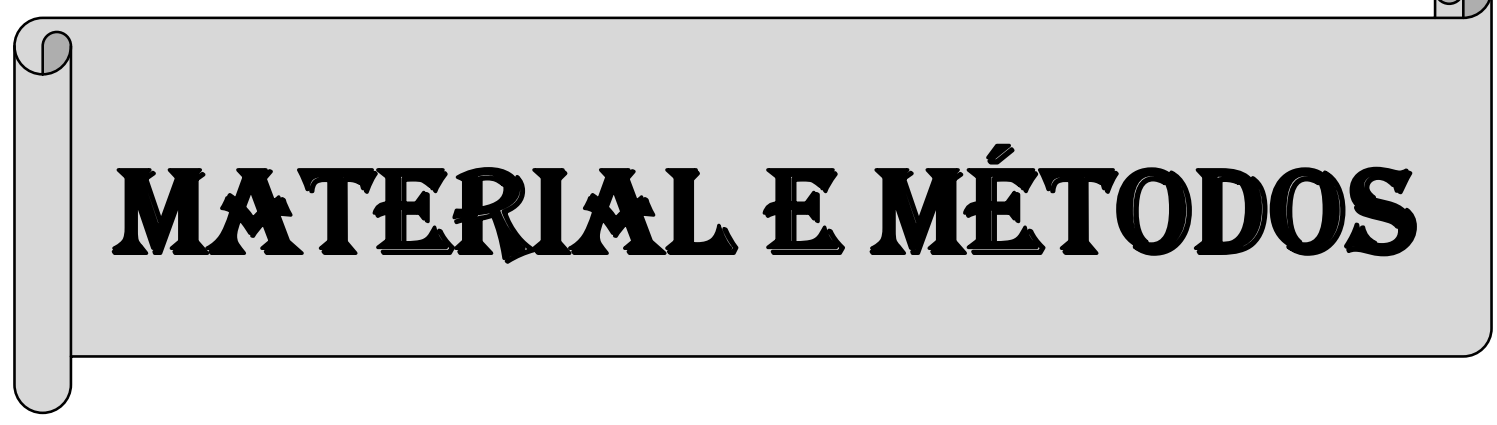




\section{Material e Métodos}

\subsection{Animais}

Foram utilizadas ratas Wistar adultas, com 2 a 3 meses de idade e $200 \mathrm{~g} \pm 5 \%$ de peso corporal. Os animais foram mantidos em gaiolas coletivas (cinco por gaiola) em ambiente com temperatura constante de $23 \pm 20$ ㅇ C e sob ciclo de iluminação (claro/escuro) de 12/12 horas (acendimento das luzes artificiais às $7 \mathrm{~h}$ ), tendo livre acesso à água e dieta padrão composta por ração comercial. As ratas foram cedidas pelo Biotério do Instituto de Ciências Biomédicas (ICB) da Universidade de São Paulo. Os procedimentos experimentais que foram empregados no presente trabalho estão de acordo com os Princípios Éticos de Experimentação Animal, adotados pela Sociedade Brasileira de Ciências de Animais de Laboratório (SBCAL) e foram aprovados pela Comissão de Ética em Experimentação Animal do ICB USP (Protocolo CEEA 071.09).

\subsection{Extração das ilhotas pancreáticas}

A obtenção das ilhotas foi realizada pelo método da digestão do pâncreas exócrino pela colagenase, de acordo com técnicas já estabelecidas (LACY; KOSTIANOVSKY, 1967). Os animais foram sacrificados em guilhotina, exsanguinados, e submetidos à antissepsia da região abdominal com álcool 70\%. Após laparotomia e exposição do ducto biliar comum, este foi clampeado na sua extremidade distal, junto ao duodeno, e dissecado próximo ao pedículo hepático, por onde foi introduzida uma cânula de polietileno e injetados retrogradamente cerca de $20 \mathrm{~mL}$ de solução de colagenase a $0,68 \mathrm{mg} / \mathrm{mL}$ (colagenase tipo V) em Hanks. Após divulsão do tecido acinar, o pâncreas foi retirado e colocado em uma placa de Petri para dissecação de gânglios linfáticos, gorduras e vasos sanguíneos. O tecido foi colocado em tubo cônico tipo Falcon em banho-maria a 37으 C durante 22 minutos, seguido de agitação manual no mesmo banho-maria por mais 1 minuto, para a digestão da parte exócrina do pâncreas. Posteriormente, foram feitas lavagens sucessivas do conteúdo do tubo, para ressuspensão do material isolado com solução de Hanks. A solução final foi depositada em placa de Petri para coleta das ilhotas com o emprego de micropipeta e lupa. De 300 a 500 ilhotas foram coletadas e lavadas com solução de Krebs-Henseleit. 


\subsection{Dispersão de ilhotas}

Para os experimentos em que utilizamos o citômetro de fluxo, as ilhotas pancreáticas em cultura foram dispersas com tripsina. Depois de coletadas cerca de 30 ilhotas em cada tubo cônico e da sedimentação das mesmas no fundo do tubo, o meio de cultura foi cuidadosamente removido e $150 \mu \mathrm{L}$ de tripsina pré-aquecida a 36 o $\mathrm{C}$ foi adicionada. Em seguida, agitou-se os tubos levemente por 2 minutos em banho-maria a 36 oC. Logo após foi acrescido $500 \mu \mathrm{L}$ de meio RPMI com soro fetal bovino (SFB) para neutralizar a enzima. Os tubos foram então centrifugados a $1000 \mathrm{rpm}$ por 3 minutos a 10 으. O sobrenadante foi cuidadosamente retirado de cada tubo e $200 \mu \mathrm{L}$ de meio foi acrescentado. Com auxílio da micropipeta as ilhotas foram dispersas cuidadosamente através da aspiração até que não se observasse mais as ilhotas a olho nu.

\subsection{Cultura de ilhotas}

Para os experimentos em que as ilhotas ficaram em cultura, o Hanks usado na obtenção do tecido foi suplementado com os antibióticos penicilina/estreptomicina e filtrado. Todo o material cirúrgico foi banhado com álcool $70 \%$ e a seringa, cânula e tubos cônicos usados eram novos e estéreis. A extração do tecido pancreático se deu como citado no item anterior. Após a agitação manual da preparação de pâncreas em solução de colagenase, todos os procedimentos ocorreram no fluxo laminar para cultura primária. Para facilitar o trabalho e evitar contaminações, a separação das ilhotas pancreáticas do tecido acinar exócrino se deu através de gradiente de densidade criado por uma solução de polissacarídeos, o Histopaque ${ }^{\circledR} 1077$ (Sigma-Aldrich Co.), e centrifugação. As ilhotas, após o isolamento, foram mantidas em meio de cultura RPMI suplementado com penicilina/estreptomicina, $10 \%$ de soro fetal bovino e $10 \mathrm{mM}$ glicose. As placas contendo as ilhotas foram mantidas em incubadora com atmosfera contendo $5 \%$ de $\mathrm{CO}_{2}$, a $37 \stackrel{\text { o }}{\text {, por }}$ 24h. Após este período, as ilhotas foram divididas entre as diferentes concentrações de glicose para realização dos ensaios. Consideramos as concentrações de 2,8 e 5,6 mM como baixa glicose, as concentrações intermediárias de 8,3 e 11,1 mM (mais próximas do controle de ilhotas e células beta em cultura, já que as mesmas são cultivadas entre 10 e 11,1 mM de glicose), enquanto que 16,7 e $20 \mathrm{mM}$ foram consideradas como alta glicose. 


\subsection{Cultivo celular}

Nos experimentos in vitro foram utilizadas as linhagens de célula beta de rato INS1E e INS 832-13, ambas derivadas da linhagem matriz INS-1. O objetivo da seleção que as originou era obter linhagens mais homogêneas, uma vez que INS-1 não é clonal, pois se originou de insulinoma de rato causado por irradiação de raios $X$ e assim, apresenta grande heterogeneidade. Além disso, buscavam uma resposta secretória similar à das ilhotas pancreáticas, já que a linhagem mãe, apesar de responsiva a glicose, tem uma resposta bem menor do que o tecido primário. A primeira a surgir foi a INS 832/13, que foi produzida através da superexpressão do gene humano da pró-insulina em INS-1. Dentre os clones obtidos, essa linhagem foi selecionada por apresentar uma potente secreção de insulina, por também ser responsiva a outros secretagogos como carbacol, GLP-1 e palmitato, além de possuir canais de $\mathrm{K}^{+}$dependentes de voltagem ativos (HOHMEIER et al., 2000). Já a INS-1E é uma linhagem clonal selecionada por ter um conteúdo satisfatório de insulina e responder à glicose de forma semelhante às ilhotas, porém sem nenhuma manipulação genética. Não somente em relação à secreção de insulina, ela também é semelhante às ilhotas em relação à metabolização da glicose com níveis aumentados de $\mathrm{NAD}(\mathrm{P}) \mathrm{H}$ e apresentando variações do cálcio citossólico e mitocondrial. A resposta secretória aos aminoácidos e sulfonilureia também é similar à de ilhotas pancreáticas de ratos (MERGLEN et al., 2004). Por estas características, as células INS são algumas das melhores linhagens de células beta dentre as inúmeras disponíveis hoje para estudos in vitro, que incluem BRIN-BD11, MIN-6, NIT-1, RINm, HIT (SKELIN et al., 2010).

As duas linhagens foram cultivadas em atmosfera umidificada contendo $5 \% \mathrm{CO}_{2}$ em meio RPMI 1640 completo suplementado com 10\% SFB (soro fetal bovino), 1 mM piruvato de sódio, $50 \mu \mathrm{M}$ 2-mercaptoetanol, 2 mM glutamina, 10 mM HEPES, $100 \mathrm{U} / \mathrm{ml}$ penicillina e $100 \mu \mathrm{g} / \mathrm{mL}$ estreptomicina, conforme protocolo já descrito (MERGLEN et al., 2004). A manutenção do cultivo se deu através de uma tripsinização por semana, sendo cultivadas $3,5 \times 10^{6}$ células em cada garrafa de $75 \mathrm{~cm}^{2}$ contendo $20 \mathrm{~mL}$ de meio completo. Para os experimentos, foram cultivadas $5 \times 10^{5}$ células em cada poço das placas para cultivo aderente de 6 poços. Foram utilizadas células INS-1E apenas entre as passagens 60 a 80, período no qual a linhagem mantém homogeneidade e estabilidade (MERGLEN et al., 2004). 
Já a INS 832/13 é sabidamente estável entre as passagens 26 a 92, mas foram utilizadas preferencialmente células entre as passagens 50 e 60 .

\subsection{Extração de RNA}

Para a extração dos RNAs totais, foram utilizadas cerca de 300-500 ilhotas ou células INS-1E cultivadas a $1 \times 10^{7}$. Os tecidos foram inicialmente lisados e homogeneizados com o regente Trizol $^{\oplus}$ (Invitrogen, EUA), até a completa solubilização. Os RNAs obtidos foram quantificados por espectrofotometria nos comprimentos de onda de 260 e $280 \mathrm{~nm}$. O grau de pureza do RNA foi determinado pela relação dos valores de leitura da absorbância a 260 e $280 \mathrm{~nm}$ (valores próximos a 2,0 $\pm 0,05$ indicam alto grau de pureza). Foi realizada eletroforese para separação do RNA em gel de agarose (1\%) com brometo de etídio. Após a separação por eletroforese, foram visualizadas as bandas $18 \mathrm{~S}$ e $28 \mathrm{~S}$ por exposição do gel à luz ultravioleta, demonstrando a integridade do RNA (Figura 9).

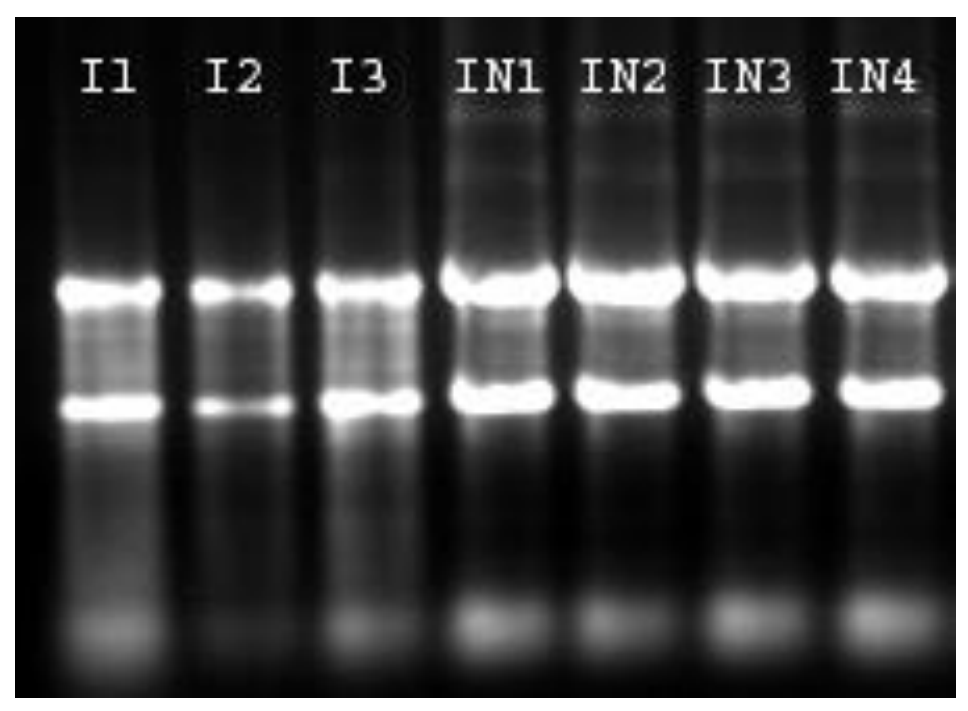

FIGURA 9 - Integridade do RNAm. Foto representativa do gel de agarose para visualização das bandas $18 \mathrm{~S}$ e $28 \mathrm{~S}$ para demonstração da integridade das amostras de RNA utilizadas para a produção de cDNA, que posteriormente foi utilizado na técnica de PCR em tempo real. Legenda: 11-3: amostras de ilhotas pancreáticas; IN1-4: amostras da linhagem INS$1 \mathrm{E}$. Foto representativa dos experimentos realizados.

\subsection{PCR em tempo real}

Cada amostra de RNA foi submetida à reação de transcrição reversa com primers randômicos. A cada tubo foram adicionados: $3 \mu \mathrm{g}$ de RNA total, tampão DNAse 10x e DNAse $(1 \mathrm{U} / \mu \mathrm{L})$. Após incubação por 25 minutos a 25으 C, a DNAse foi inibida com EDTA (25 mM) e, 
em seguida, foram adicionados primers randômicos (146 ng/ $\mu \mathrm{L}$ ) e os reagentes tampão RT 5x, DTT (100 mM) e dNTP mix (10 mM). A enzima Tanscriptase Reversa SuperScript III foi adicionada e as amostras foram incubadas. A reação foi realizada utilizando termociclador Multicycler PTC-0200 (Mj Research, Inc, Walhan, MA, USA).

A expressão gênica foi então avaliada por PCR em tempo real utilizando o equipamento ROTOR GENE 6000 (Corbett Research, Mortlake, Australia) e o SYBR GREEN (Invitrogen, Carlsbad, CA, EUA) para quantificação fluorimétrica. A expressão do HPRT (hipoxantina fosforribosil transferase) foi determinada em paralelo com o controle. A lista com a sequência dos primers utilizados está na Tabela 1 a seguir.

TABELA 1: Primers Utilizados na Reação de PCR em Tempo Real.

\begin{tabular}{|c|c|}
\hline Primer & Sequência \\
\hline p47 phox & $\begin{array}{l}\text { sense: CTTCATTCGCCACATCGC } \\
\text { antisense: TTTCTGTAGACCACCTTCTCCG }\end{array}$ \\
\hline gp91 ${ }^{\text {phox }}$ & $\begin{array}{l}\text { sense: TGCCCAGTACCAAAGTTTGCC } \\
\text { antisense: GACCCACGATCCATTTCCAAG }\end{array}$ \\
\hline p67 $7^{\text {phox }}$ & $\begin{array}{l}\text { sense: TACACCATCCTGGACAACCTGC } \\
\text { antisense: TCCTCGCTGGAAGTAAGCCAC }\end{array}$ \\
\hline p22 $2^{\text {phox }}$ & $\begin{array}{l}\text { sense: GAGGTCCGCAAGAAGCCAAG } \\
\text { antisense: GAAACTCAAGCAGGAGCCACTG }\end{array}$ \\
\hline $\mathrm{p} 40^{\text {phox }}$ & $\begin{array}{l}\text { sense: GCCATCTCAGCCAACATCGC } \\
\text { antisense: TCTTGCTCTCTGGTCCAAACCG }\end{array}$ \\
\hline Nox1 & $\begin{array}{l}\text { sense: CTTCCTCACTGGCTGGGATA } \\
\text { antisense: CGACAGCATTTGCGCAGGCT }\end{array}$ \\
\hline Nox4 & $\begin{array}{l}\text { sense: CCTCTGCTGCTTGTTTGGCTG } \\
\text { antisense: GCTAGGGACCTTCTGTGATCCG }\end{array}$ \\
\hline Noxa & $\begin{array}{l}\text { sense: GTACTTCAACATGGGCTGCGTG } \\
\text { antisense: TGGTCACTGCTTGGTCAAATGC }\end{array}$ \\
\hline Noxo & $\begin{array}{l}\text { sense: TGGCAAGTCCAAGACACCCAG } \\
\text { antisense: CCAGCACACAGAGAAGGCAAAC }\end{array}$ \\
\hline HPRT & $\begin{array}{l}\text { sense: GCTGAAGATTTGGAAAAGGTGT } \\
\text { antisense: ACAGAGGGCCACAATGTGAT }\end{array}$ \\
\hline
\end{tabular}


A intensidade de expressão de cada gene foi obtida pelos valores de CT (Threshold cycle) ou limiar do ciclo, no qual o aumento no sinal associado à fase exponencial de amplificação do produto de RT-PCR começa a ser detectada. O valor do CT é o número de ciclos calculado no qual o produto do RT-PCR atinge um limiar de deteç̧ão. Trata-se do ciclo em que a fluorescência detectada é estatisticamente diferente do efeito de fundo (background). O CT é inversamente proporcional ao log do número de cópias da amostra, de maneira que quanto maior a expressão de determinado gene na amostra, menos ciclos são necessários para o alcance do CT (LIVAK; SCHMITTGEN, 2001).

Para a quantificação relativa dos produtos de amplificação, foi feita a análise de eficiência de amplificação dos genes alvos e do controle interno. Para isso, foram produzidas curvas de amplificação com diluições seriadas do cDNA das ilhotas, em: 1/16, 1/32, 1/64, 1/128, 1/256, 1/512 e uma amostra em branco (NTC - non template control, ou seja, sem cDNA algum), para cada um dos primers utilizados. A eficiência de cada primer foi obtida com o cálculo da inclinação da reta (slope) dos pontos de CT observados em relação à concentração de cDNA presente na amostra, calculadas de acordo com a fórmula: $E=10-1 / a$ onde a é o coeficiente angular da reta (PFAFFL, 2001).

\subsection{Análise proteica por Immunoblotting}

Para análise da expressão proteica das enzimas antioxidantes e dos componentes da NADPH oxidase, $1,0 \times 10^{6}$ células foram incubadas por 24 horas em placas de seis poços com $2 \mathrm{ml}$ de meio RPMI com 11,1 mM de glicose e em seguida por 48 horas com diferentes concentrações de glicose. Após o período de incubação a extração da proteína foi realizada com o tampão de lise RIPA (Millipore) dez vezes concentrado, de acordo com as recomendações do fabricante. A quantidade de proteína presente em cada amostra foi determinada através do método de Bradford, utilizando albumina bovina como padrão. Após o cálculo da concentração de cada amostra, $15 \mu \mathrm{g}$ de proteína total foi submetida à eletroforese em gel de poliacrilamida (SDS-PAGE 12\%). A transferência das proteínas separadas em gel foi feita eletricamente para uma membrana de nitrocelulose, por 2 horas a $120 \mathrm{~V}$, como descrito anteriormente (TOWBIN et al., 1979). A ligação inespecífica de proteínas na membrana de nitrocelulose foi diminuída pela incubação destas com uma solução bloqueadora (leite desnatado Molico 5\%, Tris $10 \mathrm{mM}, \mathrm{NaCl} 150 \mathrm{mM}$ e Tween 20 
$0,02 \%)$ a temperatura ambiente por 1 hora. Estas membranas foram então incubadas com anticorpo primário (Tabela 2) em solução bloqueadora (com 3\% de BSA) por 24 horas a 4 @C e em seguida lavadas com esta mesma solução sem leite ou BSA, por 30 minutos. Estas membranas foram então incubadas com anticorpo secundário anti-IgG conjugado com peroxidase (Amersham Bioscences, Reino Unido) por 1 hora a temperatura ambiente. Em seguida, as membranas foram incubadas com solução de ECL (GE Healthcare, Oslo, Noruega) para detecção das bandas por quimioluminescência. As membranas tiveram a luminescência de suas bandas avaliadas por sistemas de detecção de quimioluminescência informatizados, Image Quant 350 (GE Healthcare, Oslo, Noruega). A análise quantitativa das bandas foi feita por densitometria com o auxílio do programa ImageJ (Wayne Rasband, National Institute of Health, Estados Unidos).

TABELA 2 - LISTA DE ANTICORPOS USADOS

\begin{tabular}{|c|c|c|c|}
\hline ANTICORPO 10 & FABRICANTE & TIPO & ANTICORPO 20 \\
\hline RAC1 & SANTA CRUZ BIOTECHNOLOGY & POLICLONAL & RABBIT \\
\hline GP91 ${ }^{\text {PHOX }}$ & UPSTATE & POLICLONAL & RABBIT \\
\hline SOD1 & SANTA CRUZ BIOTECHNOLOGY & POLICLONAL & RABBIT \\
\hline SOD2 & MILLIPORE & POLICLONAL & RABBIT \\
\hline CATALASE & SIGMA-ALDRICH & MONOCLONAL & MOUSE \\
\hline TIORREDOXINA & MILLIPORE & POLICLONAL & RABBIT \\
\hline GLUTATIONA PEROXIDASE & SIGMA-ALDRICH & POLICLONAL & GOAT \\
\hline ALFA-TUBULINA & INVITROGEN & MONOCLONAL & MOUSE \\
\hline
\end{tabular}

\subsection{Estudos de imuno-histoquímica e microscopia de fluorescência}

Para avaliar se havia interação entre Rac1 e Sod1 foram realizados experimentos de imuno-histoquímica. Cerca de $5 \times 10^{5}$ células INS 832-13 cresceram em lamínulas redondas de $40 \mathrm{~mm}$ por $24 \mathrm{~h}$. No dia posterior ficaram overnight com RPMI com baixo soro $(2,5 \%$ de 
soro fetal bovino) e glicose $(2,8 \mathrm{mM})$. Em seguida, foram lavadas e pré-incubadas com tampão Krebs Ringer (ou KRB - Krebs ringer buffer) com 0,1\% de albumina e 2,8 mM de glicose por 1 hora. Depois foram incubadas com o mesmo tampão na presença de baixa $(2,8$ $\mathrm{mM}$ ) e alta (20 mM) glicose por apenas 15 minutos. Este tempo foi definido por ter sido apontado como o tempo de ativação de Rac1 por glicose e também da interação máxima entre Rac1 e Sod1 (LI et al., 2004; HARRAZ et al., 2008). Após a incubação, as células foram lavadas com PBS e incubadas a temperatura ambiente por 30 min com paraformaldeído $1 \%$ para fixação. Após uma lavagem de 5 minutos com PBS seguiu-se a incubação das lâminas com Triton 0,5\% por 15 min para a permeabilização das células. Por fim, após mais três lavagens com PBS, o bloqueio é feito com solução de albumina 5\% em PBS mais $10 \%$ de goat serum por $2 \mathrm{~h}$. Durante a noite ocorreu a incubação com os anticorpos primários para Rac1 e Sod1, exceto o controle negativo que foi incubado com a solução de albumina 5\% em PBS. Após três lavagens com PBS as amostras foram incubadas com os anticorpos secundários anti-rabbit e anti-mouse (1:500) por duas horas. Em seguida foram realizadas mais quatro lavagens de cinco minutos com PBS e as lâminas foram montadas então com meio antifading de montagem Vectashield (Vector Laboratories, California, Estados Unidos) já com DAPI para marcar o núcleo. As lâminas foram visualizadas no dia seguinte com o microscópio de fluorescência Zeiss ApoTome (Zeiss, Alemanha) nas objetivas com aumento de 10, 20 e 40 vezes. Todos os parâmetros de intensidade e ganho foram padronizados para todas as amostras, inclusive o controle negativo.

\subsection{Estudos de translocação}

Para avaliar a translocação de Rac1 para a membrana citoplasmática e a possibilidade da migração concomitante de Sod1, foram realizados alguns experimentos com separação das frações do citosol e da membrana dos extratos celulares totais. Foram cultivadas $1,0 \times 10^{7}$ células INS 1E em placas de $100 \mathrm{~mm}$. Após 48 horas, foram lavadas com PBS e ficaram em pré-incubação por 1 hora com KH 11,1 mM de glicose. A incubação com baixa e alta glicose (2,8 e $20 \mathrm{mM}$ ) foi de $15 \mathrm{~min}$. Após este período, as células foram lavadas com PBS gelado e foi adicionado $150 \mu \mathrm{L}$ tampão de homogeneização (Tris $10 \mathrm{mM}$, EDTA $1 \mathrm{mM}$, sacarose $250 \mathrm{mM}$ ) acrescido de inibidores de proteases (leupeptina e aprotinina) e fosfatases (pirofosfato de sódio, fluoreto de sódio e ortovanadato de sódio). Foram homogeneizadas, 
sonicadas e transferidas para microtubos identificados. As amostras passaram pelo processo de purificação de membrana. As células foram centrifugadas a 1000 g 4 oC por 15 minutos para separação por sedimentação do núcleo, esse foi descartado e o sobrenadante foi novamente centrifugado a $12000 \mathrm{~g} 4$ ㅇ C por 15 minutos para separação por sedimentação da membrana plasmática. Nesse ponto, o sobrenadante foi armazenado como proteínas citosólicas, enquanto o precipitado (membrana plasmática) foi novamente suspendido em tampão de homogeneização e as proteínas foram quantificadas pelo método de Bradford em espectrofotômetro. De cada amostra avaliada, $15 \mu \mathrm{g}$ de proteínas diluídas em tampão laemmli foram submetidas à eletroforese em gel de poliacrilamida (SDS -PAGE 12\%) seguida de transferência para membrana de nitrocelulose. A membrana foi tratada com solução bloqueadora ( $10 \%$ de leite em pó desnatado) em seguida incubada com anticorpo primário policlonal anti-Rac1 (Upstate) ou anti-Sod1 (Santa Cruz Biotechnology) e com anticorpos secundários anti-IgG (Amersham Bioscences) marcados com peroxidase. Posteriormente, a membrana foi exposta ao ECL (Amersham Bioscences) e a luminescência foi revelada em foto documentador, Image Quant 350 (GE Healthcare, Oslo, Noruega).

\subsection{Avaliação do conteúdo de superóxido citosólico por DHE e mitocondrial pelo Mitosox}

A produção do superóxido foi determinada utilizando o método de fluorescência com diidroetídeo (BINDOKAS et al., 2003). A Hidroetidina (EH) ou Diidroetídeo (DHE) é uma sonda redox-sensível, extensamente usada para detectar a produção intracelular de ânion superóxido. A reação entre o superóxido e o DHE resulta na formação de um produto oxidado a um produto fluorescente (excitação $480 \mathrm{~nm}$; emissão, $567 \mathrm{~nm}$ ) que é totalmente diferente do etídio, como se havia pensando anteriormente. O DHE citoplasmático apresenta fluorescência azul. No entanto, em contato na presença do DNA esse composto formado entre a oxidação da DHE e do superóxido apresenta um aumento da fluorescência (ZHAO et al., 2003). O mitosox ${ }^{\circledR}$ é o DHE com um tag direcionador para mitocôndria.

Cerca de 30 ilhotas pancreáticas ou células INS-1E cultivadas a $5 \times 10^{5}$ em placas de 24 poços foram incubadas por 1 ou 48 horas em meio RPMI com as concentrações de 2,8, $5,6,8,3,11,1,16,7$ ou $20 \mathrm{mM}$ de glicose a $37 \stackrel{\circ}{ } \mathrm{C}$. Para os experimentos com inibição da NADPH oxidase foram usadas as concentrações de $0,2,8$ ou $16,7 \mathrm{mM}$ glicose de na 
presença ou ausência de 20, 60 e $100 \mu \mathrm{M}$ de NSC23766, inibidor de Tiam1. Após este período, adicionou-se DHE (Invitrogen) ou mitosox ${ }^{\circledR}$ (Molecular Probes), atingindo uma concentração final de $25 \mu \mathrm{M}$ para o DHE e $15 \mu \mathrm{M}$ para o mitosox ${ }^{\circledR}$ e incubou-se por 20 minutos sob agitação, a temperatura ambiente, ao abrigo da luz. Em seguida, a solução de incubação foi retirada, as células ou ilhotas foram lavadas em Krebs-Henseleit sem glicose e tripsinizadas ou dispersas, respectivamente. A fluorescência foi avaliada em um citômetro de fluxo Guava easyCyte 8HT (Millipore, Hayward, CA, Estados Unidos) com excitação em $488 \mathrm{~nm}$ e emissão em 583/26 nm. Os histogramas foram analisados utilizando-se o programa Guava soft 1.1.

\subsection{Morte celular}

A morte celular das células INS-1E foi avaliada pelo reagente Via Count ${ }^{\circledR}$ (Millipore, MA, Estados Unidos), que possui dois corantes de ligação ao DNA para identificar células viáveis, mortas e em processo de apoptose. As células INS-1E foram plaqueadas com $5 \times 10^{5}$ em placas de 6 poços em meio RPMI 1640 com 11,1 mM de glicose em pH 7,4 e mantidas até o dia seguinte em atmosfera de $5 \% \mathrm{CO}_{2}$, a $37 \stackrel{\circ}{\circ}$. Após o período de incubação, o meio foi substituído por RPMI com diferentes concentrações de glicose e as células foram incubadas por mais 48 horas. Após este período, o meio de incubação foi guardado (pois possui células mortas), as células aderidas foram lavadas com PBS, tripsinizadas (100 $\mu$ l de tripsina) e a tripsina foi neutralizada com $150 \mu \mathrm{l}$ de meio de cultura RPMI. O volume final total mais o meio de incubação guardado anteriormente foram transferidos para tubos e centrifugados a $1200 \mathrm{rpm}$ por 5 minutos a $4{ }^{\circ} \mathrm{C}$. O sobrenadante foi descartado e o pélete ressuspendido em $50 \mu \mathrm{l}$ de meio RPMI com 11,1 mM de glicose. Foram transferidos $25 \mu \mathrm{l}$ da suspensão para placa de leitura contendo $225 \mu \mathrm{l}$ de reagente VIA COUNT (Millipore). As células foram mantidas por cinco minutos na ausência de luz a temperatura ambiente. Após a incubação, a leitura e a fluorescência das células em suspensão foi analisada por citômetro de fluxo Guava EasyCyte (Millipore).

A apoptose nas ilhotas em cultura foi avaliada como já descrito anteriormente (PASCAL et al., 2010). Para tal, foi usado o kit Cell Death Detection ELISA PLUS (Roche Diagnostics, Mannheim, Alemanha), de acordo com as instruções do fabricante. O teste é baseado na medição da quantidade de histona associada a fragmentos de (mono- e oligo- 
nucleossomos). Após a cultura de ilhotas em diferentes concentrações de glicose por $48 \mathrm{~h}$, amostras de 80 ilhotas foram lisadas em $100 \mu$ de tampão de lise, e as frações citosólicas e nuclear foram separadas por centrifugação. A média da absorbância de cada amostra foi normalizada pelo conteúdo de DNA na fração nuclear, usando um controle positivo fornecido pelo kit.

\subsection{Ensaio de Viabilidade - MTT}

Este é um famoso ensaio de viabilidade celular pela facilidade de execução e reprodutibilidade. Seu nome deriva do composto utilizado, o sal de MTT ou brometo de 3(4,5-dimetiltiazol-2-ilo)-2,5-difeniltetrazólio, e se baseia num teste colorimétrico realizado com as células vivas. Para tal, as células foram cultivadas em triplicata para cada tratamento em placas de 96 poços. Os diferentes estímulos foram dados por 24 h. Os ensaios envolveram RPMI normal ou com baixo soro e glicose, e diferentes concentrações de glicose $(2,8 ; 11,1 ; 20 \mathrm{mM})$, e do inibidor de Sod1 $(25,5$ ou $100 \mu \mathrm{M})$, dietilcarbamato de sódio ou DETC. Após os tratamentos, é adicionado MTT em cada amostra e também em um branco, que ficam, então, em incubação por mais 2 horas. Neste período, as células viáveis reduzem o MTT (solúvel em água) através de desidrogenases mitocondriais a cristais de formazan (insolúvel em água) da cor azul púrpura. Após este período, retiramos todo o líquido de cada poço e adicionamos uma solução de solubilização do formazan (Triton X-100 10\% mais $\mathrm{HCl}$ $0,1 \mathrm{~N}$ em isopropanol anidro). Após solubilizar os cristais com pipetagem é realizada então a leitura num espectrofotômetro a $570 \mathrm{~nm}$ e para retirar a absorbância de fundo é necessário ler também as amostras a $690 \mathrm{~nm}$ e subtrair a primeira medida desta última.

\subsection{Secreção e Conteúdo Total de Insulina}

Células INS 832/13 foram cultivadas em placas de seis poços e, no dia seguinte, foram incubadas por $24 \mathrm{~h}$ com RPMI com baixo soro fetal bovino e glicose. Metade da placa (3 poços) foi tratada também com $50 \mu \mathrm{M}$ de DETC. Para o experimento, as células foram lavadas com tampão KRB sem glicose e foram pré-incubadas por 1 hora a 36 ㄷ com KRB mais $0,5 \%$ de albumina e $2,8 \mathrm{mM}$ de glicose, sempre mantendo $50 \mu \mathrm{M}$ DETC nas amostras tratadas. Em seguida, o meio foi trocado pela mesma solução para 30 minutos de incubação 
com baixa glicose (um $\mathrm{mL}$ por poço). Após a primeira incubação, o meio é recolhido e segue a segunda parte da incubação com alta glicose $(20 \mathrm{mM})$, no mesmo esquema anterior. Ao fim, foi dado um spin nos tubos de cada amostra e o sobrenadante foi recolhido e colocado em novos tubos devidamente identificados que foram, então, estocados a -20 o $\mathrm{C}$ para posterior dosagem pelo método ELISA. Às células remanescentes nos poços foi imediatamente adicionado RIPA e seguiu-se a extração e dosagem da proteína de cada poço, valor que foi usado para a correção da secreção de insulina. Este método é particularmente interessante, pois permite utilizar as mesmas amostras para verificar a secreção na presença de baixa e alta glicose o que não só aperfeiçoa o processo como também torna os dados mais fidedignos.

Para o conteúdo total de insulina foram realizados os mesmos procedimentos de cultivo e incubação por $24 \mathrm{~h}$ das células com RPMI em baixo soro e glicose, e metade das amostras incubada com $50 \mu \mathrm{M}$ de DETC. Em seguida, as células foram lavadas com PBS e a extração do total de insulina de cada amostra se deu pela solução de álcool ácido (52 partes de etanol mais 17 partes de água para 1 de HCL fumegante). Após a extração, as amostras foram armazenadas em tubos devidamente identificados a $-20 \stackrel{\circ}{\circ}$ para posterior dosagem pelo método ELISA.

\subsection{Quantificação da glutationa reduzida}

Células INS-1E foram cultivadas a $1 \times 10^{5}$ em placas de 96 poços e foram incubadas por 1 ou 48 h com diferentes concentrações de glicose $(2,8 ; 5,6 ; 8,3 ; 11,1 ; 16,7$ e 20 mM) Após o período de incubação, as células foram lavadas com tampão PBS e realizou-se a quantificação fluorimétrica da glutationa reduzida com as células vivas em crescimento com o Kit da Sigma ${ }^{\circledR}$ CS1020, cujo princípio é o método do monochlorobimane. As curvas da cinética da produção da glutationa reduzida nas células vivas foram realizadas em ensaios de 4 horas, com intervalos de leitura de 20 minutos. O comprimento de onda para a excitação foi de $360 \pm 40 \mathrm{~nm}$ e a emissão de $485 \pm 20 \mathrm{~nm}$. 


\subsection{Análise da formação de redoxossomas}

Foram cultivadas $5 \times 10^{5}$ células em lamínulas redondas de $40 \mathrm{~mm}$ de diâmetro previamente tratadas com L-poli-lisina para análise da produção de redoxossomas por microscopia confocal. Após a aderência das células (overnight) as mesmas foram lavadas com PBS e o meio de cultura trocado (volume final $1,5 \mathrm{~mL}$ ). A sonda diclorodiidrofluoresceína ou $\mathrm{H}_{2} \mathrm{DCF}$, complexada com albumina bovina, Fc OxyBURST ${ }^{\circledR}$ (Molecular Probes) foi adicionada para a concentração final de $50 \mu \mathrm{g} / \mathrm{mL}$ e incubada por 2 minutos a 36 ㄷ. Logo em seguida, TNF-alfa foi adicionado para a concentração final de 0,5 $\mathrm{ng} / \mathrm{mL}$ e incubou-se por 20 minutos a 36 ㄷ. Após a incubação, a solução foi retirada e as células foram lavadas e incubadas em PBS com 11,1 mM de glicose. Para análise da produção de redoxossomas, as lamínulas com as células aderidas foram avaliadas em microscópio confocal LSM-780-NLO do Centro de Facilidades do Instituto de Ciências Biomédicas - CEFAP (Carl Zeiss, Jena, Germany). A excitação máxima foi de $490 \mathrm{~nm}$ e a emissão máxima de $520 \mathrm{~nm}$.

\subsection{Análise dos dados}

Os resultados foram apresentados como médiatEPM (erro padrão da média). A significância estatística foi baseada no teste " $\mathrm{t}$ " ou nos testes anova one way e two way com pós-teste de Bonferroni, para a comparação dos grupos, sendo considerados significativos valores $p<0,05$. O programa utilizado para os cálculos estatísticos e confecções de gráficos foi GraphPad Prism 4. 


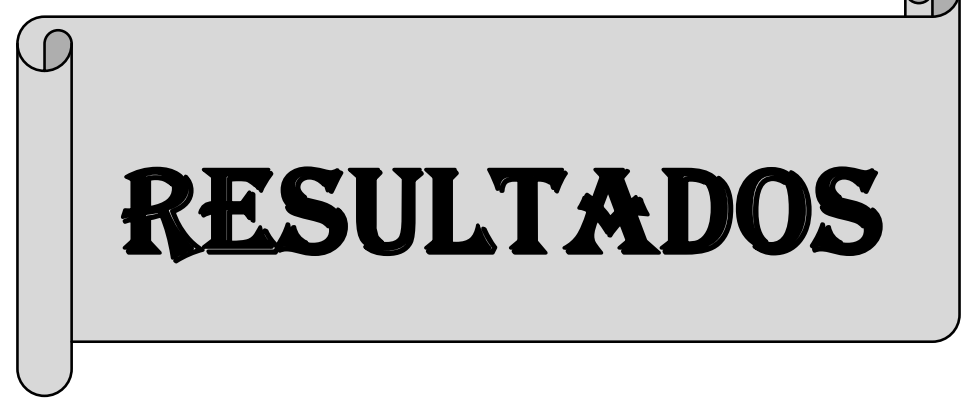




\section{Resultados}

\subsection{Expressão das proteínas de interesse}

Inicialmente verificamos a expressão das proteínas de interesse ao projeto nas linhagens celulares utilizadas no estudo. Apesar da presença da família Nox ser bem estabelecida em ilhotas pancreáticas e em algumas linhagens de célula beta, como a BRINBD11 e INS-832-13, para as células INS-1E havia sido identificada apenas a expressão proteica de $p 47^{\text {phox }}$ (OLIVEIRA et al., 2003; MORGAN et al., 2009; SYED et al., 2010). Sendo assim, para que pudéssemos utilizar esta linhagem celular como modelo experimental testou-se a expressão dos outros componentes do complexo NADPH oxidase. Confirmamos a expressão das proteínas p22 $2^{\text {phox }}$, p $47^{\text {phox }}$ e gp91 ${ }^{\text {phox }}$ por immunoblotting (Figura 10).

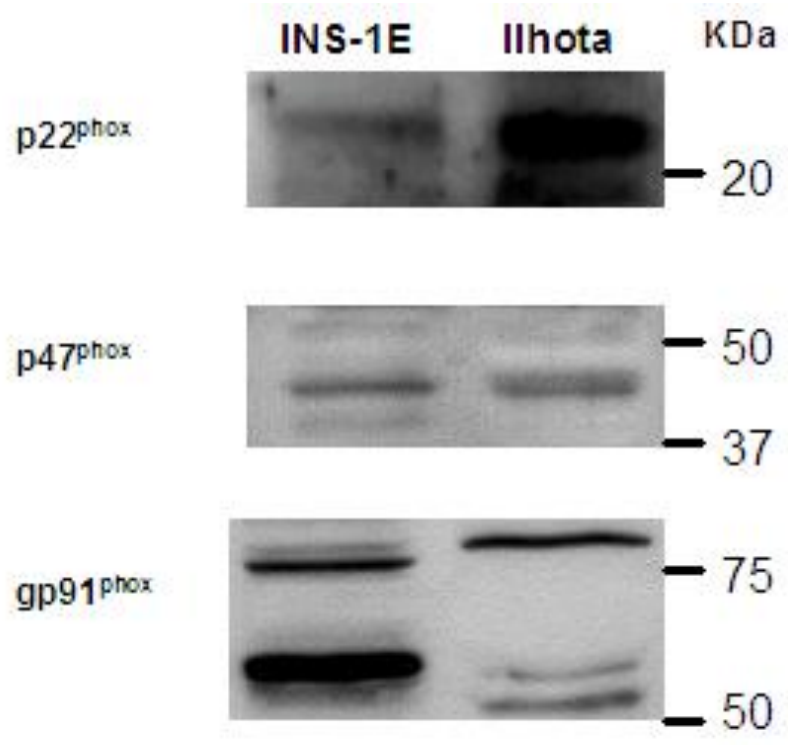

FIGURA 10: Expressão proteica dos componentes do complexo NADPH oxidase, p22 ${ }^{\text {phox }},{\mathrm{p} 47^{\text {phox }}}^{\text {e }} \mathrm{gp} 91^{\text {phox }}$, em ilhotas pancreáticas e células INS-1E. As bandas apresentadas são representativas dos resultados obtidos.

O PCR em tempo real das amostras de ilhotas pancreáticas e da linhagem INS-1E confirmou a expressão do RNA mensageiro de $\mathrm{p} 47^{\text {phox }}, \mathrm{gp} 91^{\text {phox }}, \mathrm{p} 67^{\text {phox }}, \mathrm{p} 22^{\text {phox }}, \mathrm{p} 40^{\text {phox }}$ (Figura 11), além das subunidades homólogas Nox1, Nox4, Noxa e Noxo. Também foi confirmado através de immunoblotting que ambas as linhagens, INS-1E e INS 832/13, apresentam abundante expressão proteica de Rac1 e Sod1 (Figura 12). 

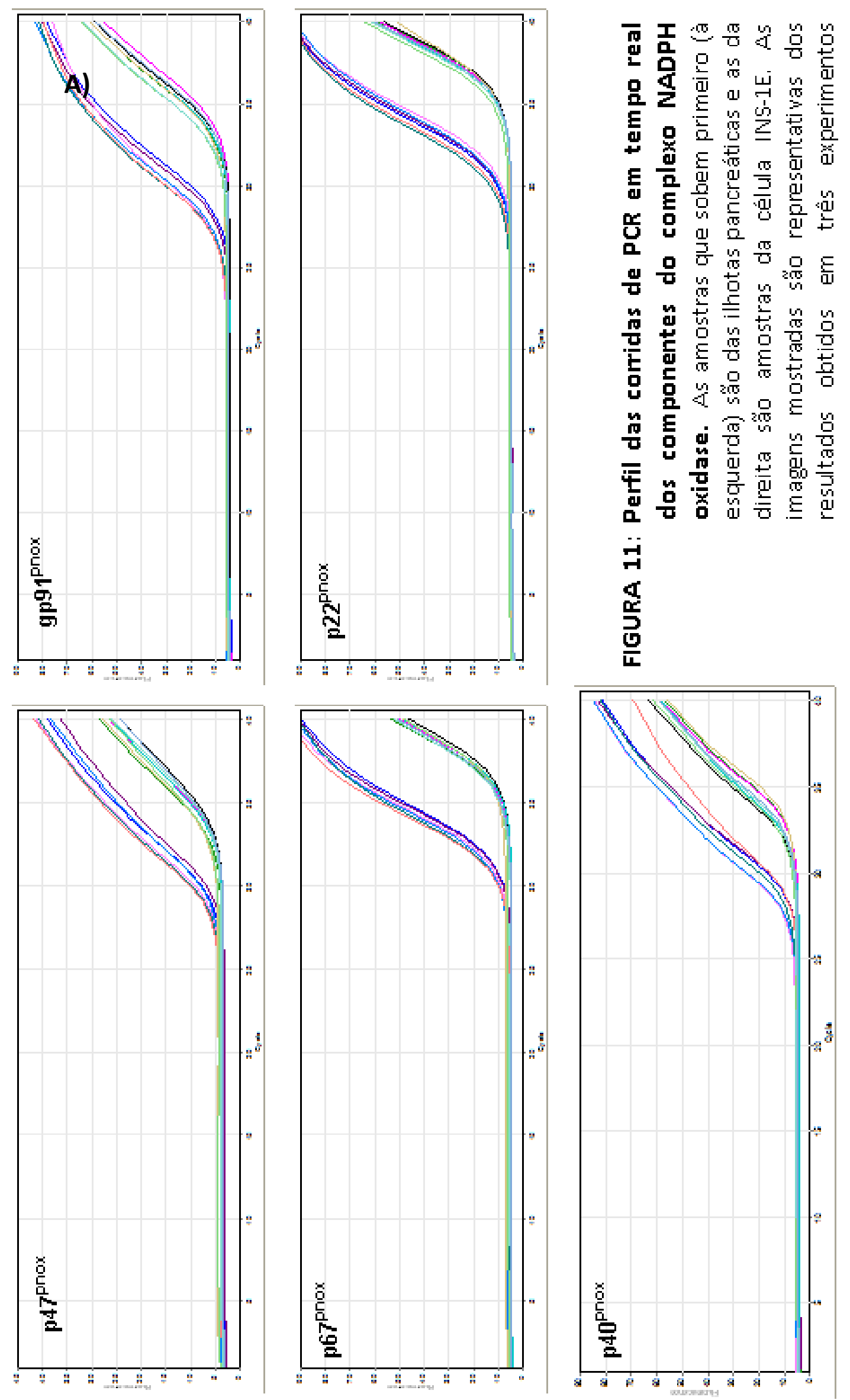
A) INS-1E

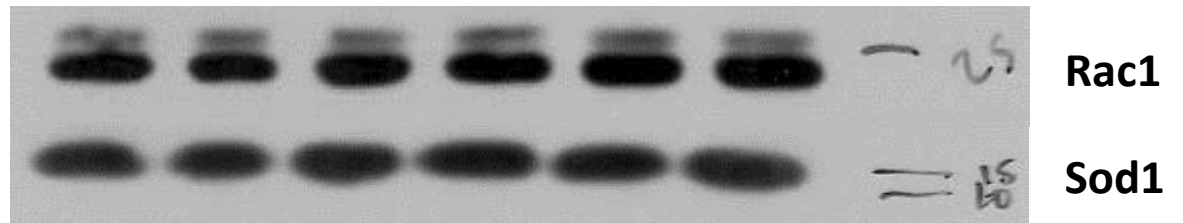

B) INS $832-13$

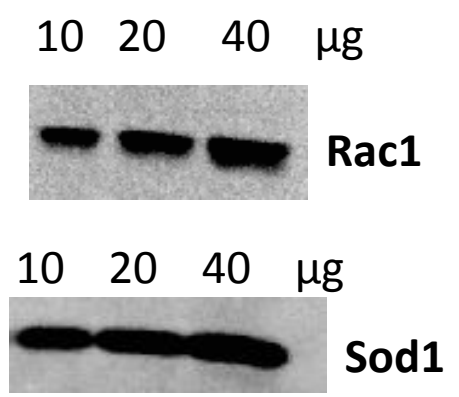

FIGURA 12: Expressão proteica basal de Rac1 e Sod1 nas linhagens celulares INS-1E (A) e INS 832/13 (B). O peso molecular de Rac1 (acima) é $22 \mathrm{KDa}$ e de Sod1 16 KDa (abaixo).

\subsection{Conteúdo de superóxido em resposta à glicose}

Como o maior estimulador da secreção de insulina das células beta pancreáticas é a glicose, observamos a resposta da produção citoplasmática de superóxido em resposta às alterações na concentração deste açúcar. Para tal, as células INS-1E e ilhotas pancreáticas isoladas foram incubadas por 1 ou 48 horas em meio RPMI com diferentes concentrações de glicose $(2,8 ; 5,6 ; 8,3 ; 11,1 ; 16,7$ e 20 mM). Estas concentrações englobam valores de hipoglicemia ( 2,8 mM ou $50 \mathrm{mg} / \mathrm{dL}$ ), normoglicemia ( 5,6 mM ou $90 \mathrm{mg} / \mathrm{dL}$ ), glicemia pósprandial de uma pessoa sadia ( 8,3 mM ou $100 \mathrm{mg} / \mathrm{dL}$ ), glicemia pós-prandial de uma pessoa com diabetes tipo 2 ( 11,1 ou $180 \mathrm{mg} / \mathrm{dL}$ ) até hiperglicemia diabética do tipo 1 ( 16,7-20 mM ou 300-334 mg/dL, respectivamente). A avaliação da produção foi feita em citômetro de fluxo com a sonda redox fluorescente dihidroetidina ou DHE (Figura 13).

Os resultados obtidos foram consistentes e demonstram uma queda no conteúdo de superóxido em resposta ao aumento da glicose. Essa resposta é mais acentuada em 48 horas. Além disso, demonstram que a linhagem INS-1E (Fig.13A) e as ilhotas pancreáticas isoladas (Fig.13B) possuem um comportamento similar. 

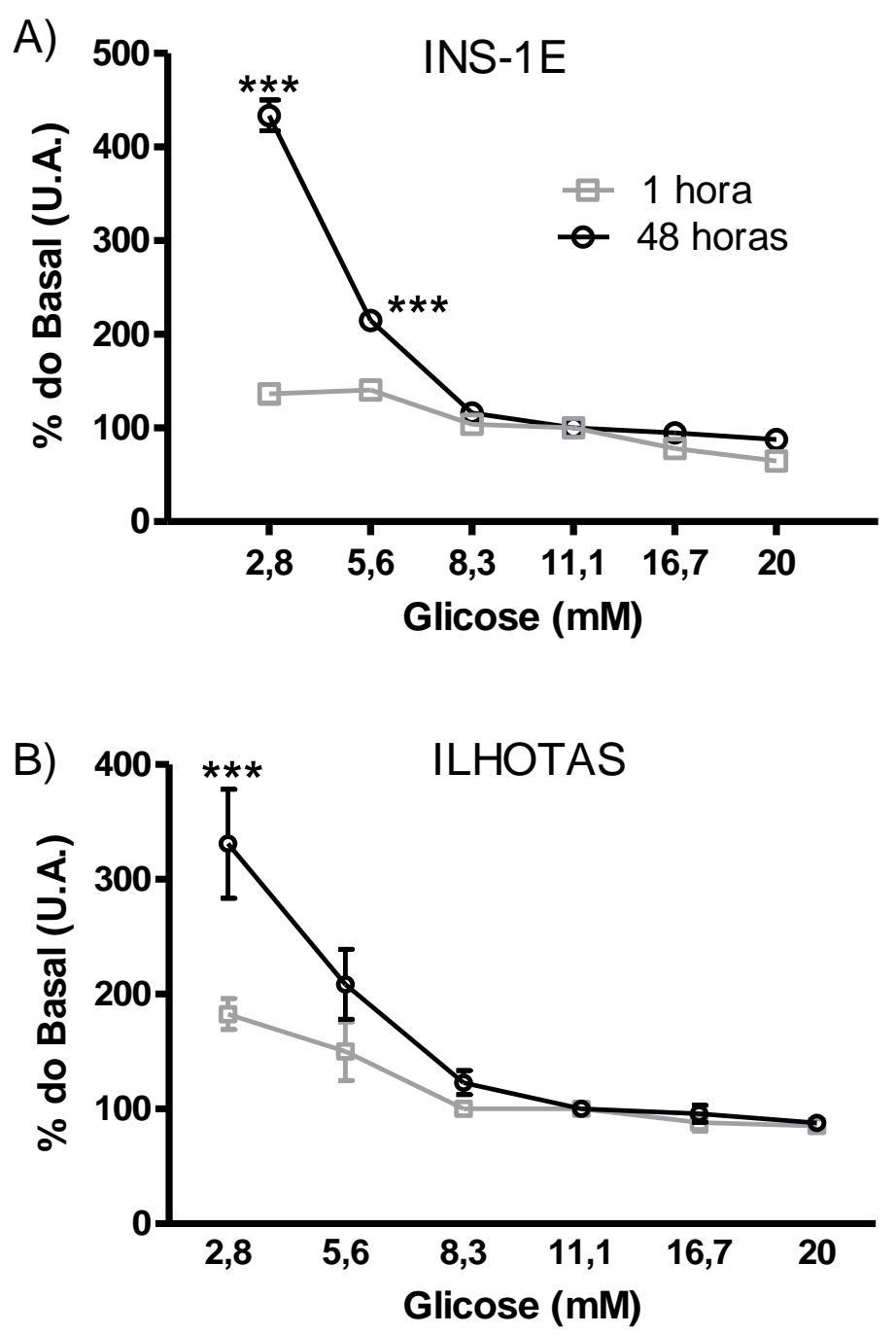

FIGURA 13: Conteúdo de superóxido em concentrações crescentes de glicose. A) Linhagem celular INS-1E. B) Ilhotas pancreáticas de rato isoladas. Após o período de incubação (1 ou $48 \mathrm{~h}$ ) foi adicionado DHE e incubado por mais 20 min. A leitura da fluorescência foi realizada por citometria de fluxo. Dados apresentados são provenientes de três a cinco experimentos independentes. A padronização dos resultados é feita sobre a glicose de cultivo $-11,1 \mathrm{mM}$. U.A.= Unidades Arbitrárias. ${ }^{* * *} \mathrm{p}<0,001$.

O uso do inibidor específico do GEF Tiam1, responsável pela ativação de Rac1 nas células beta pancreáticas, NSC23766, foi utilizado para avaliar o quanto a inativação desta pequena proteína $G$ influenciaria na produção de superóxido na presença de baixa $(2,8 \mathrm{mM})$ e alta $(16,7 \mathrm{mM})$ glicose em 1 hora. Foi observada uma inibição dose dependente na presença de baixa glicose, e um efeito menor na presença de alta glicose (Figura 14A). A partir deste efeito decidimos testar qual seria 
o efeito na ausência do açúcar. Curiosamente, não há inibição sem glicose (Figura 14B).
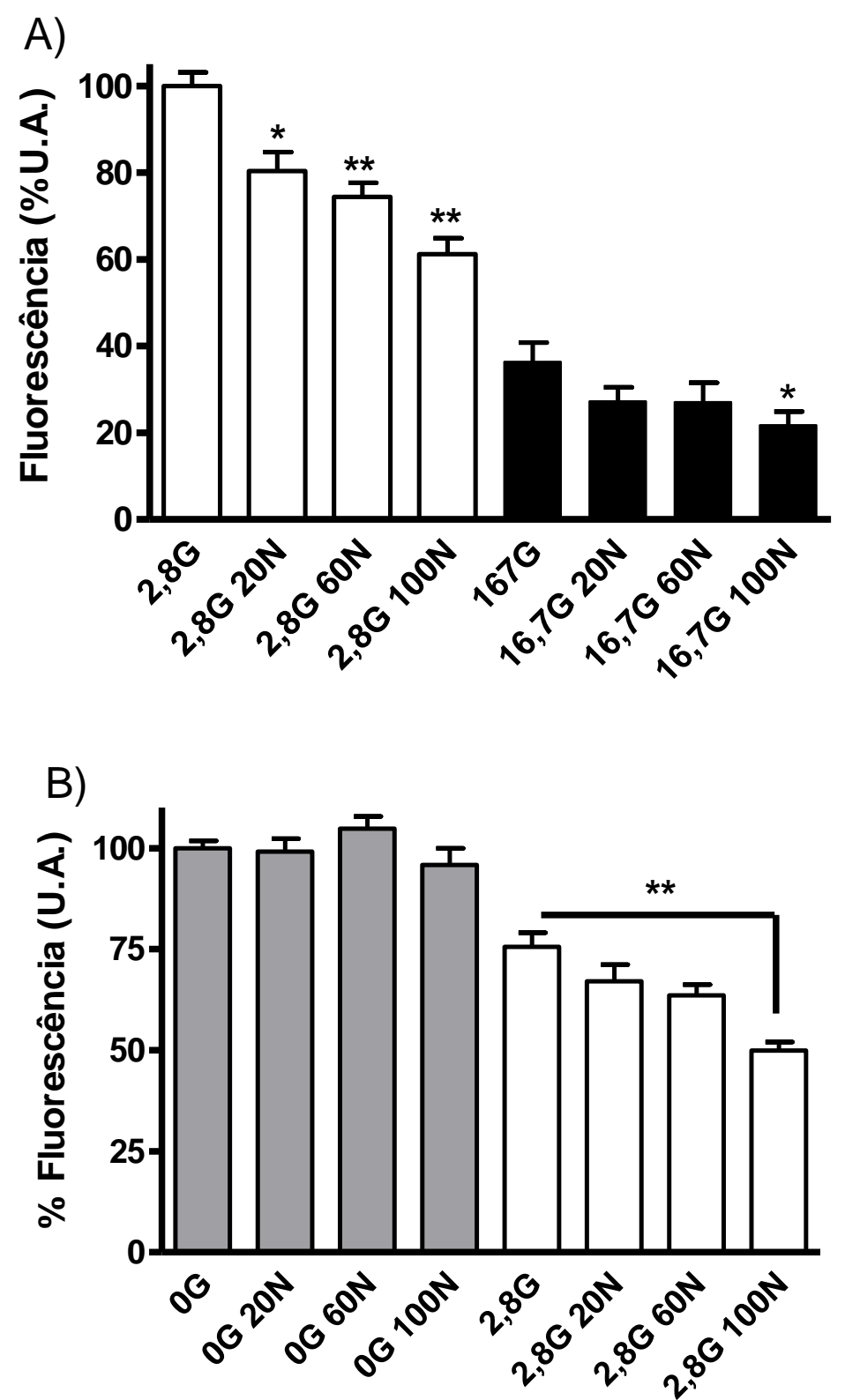

FIGURA 14: Conteúdo de superóxido em alta ou baixa glicose com ou sem inibição da NADPH oxidase. Células INS-1E foram incubadas por 1 hora com: A) 2,8 e 16,7 mM de glicose (G) ou B) 0 ou $2.8 \mathrm{mM}$ com ou sem 20, 60 e $100 \mu \mathrm{M}$ de NSC23766 (N). Após o período de incubação foi adicionado DHE e incubado por mais $20 \mathrm{~min}$. A leitura da fluorescência foi realizada por citometria de fluxo. Dados apresentados são provenientes de quatro experimentos independentes. A padronização dos resultados é feita sobre a glicose mais baixa 0 ou 2,8 mM. U.A.= Unidades Arbitrárias. ${ }^{*} p<0,05, * * p<0,005$ 


\subsection{Conteúdo mitocondrial de superóxido em resposta à glicose}

As principais fontes de superóxido das células são as proteínas NOX e a cadeia transportadora de elétrons na mitocôndria. Para avaliar o conteúdo de superóxido mitocondrial em resposta à glicose utilizamos a sonda MitoSox, que é DHE com um tag sinalizador para mitocôndria. O tratamento foi exatamente o mesmo dos experimentos com a sonda DHE, com diferentes concentrações de glicose incubadas por 1 e 48 horas em células INS-1E (Figura 15a) e ilhotas em cultura (Figura 15b).
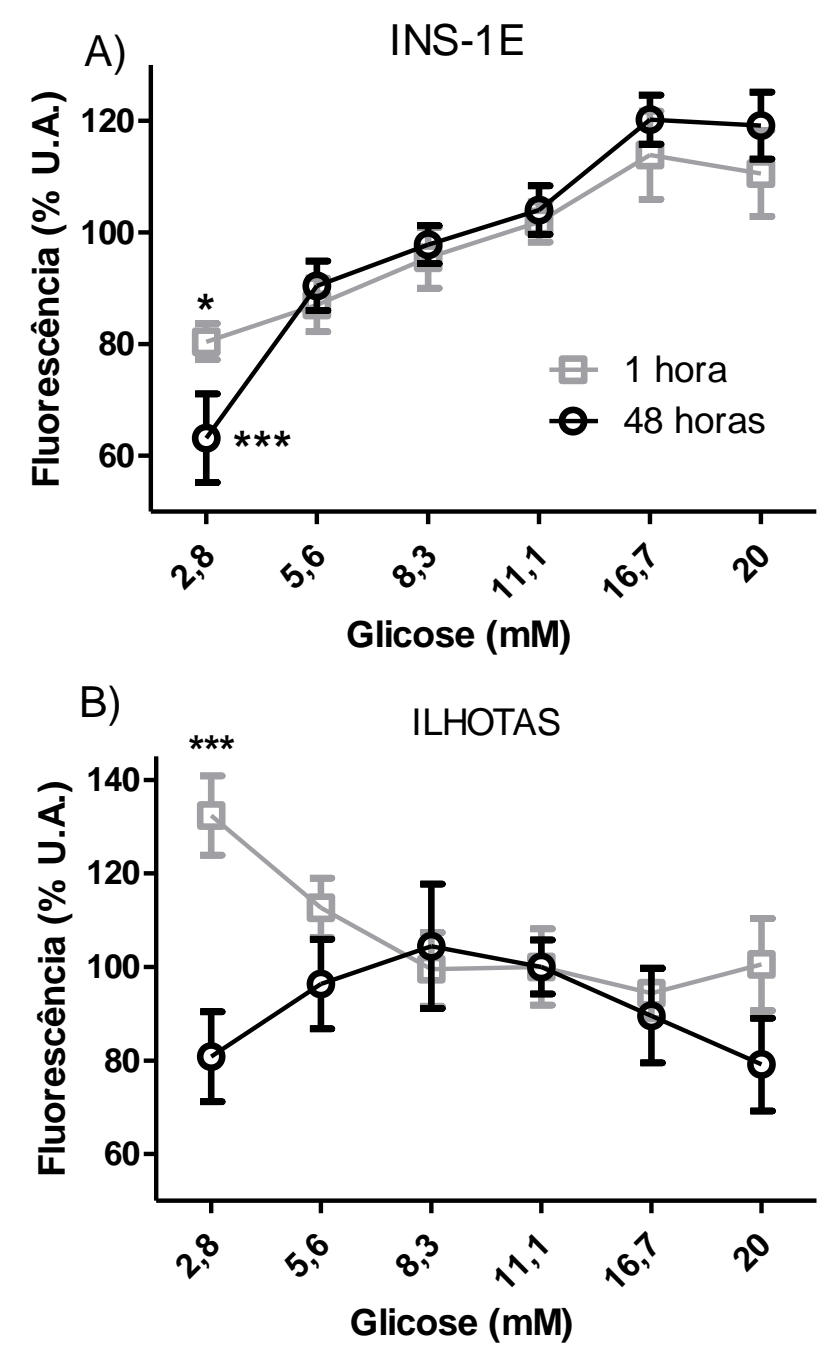

FIGURA 15: Conteúdo de superóxido mitocondrial em concentrações crescentes de glicose. A) Linhagem celular INS-1E. B) Ilhotas pancreáticas de rato isoladas. Após o período de incubação foi adicionado Mitosox e incubado por mais $20 \mathrm{~min}$. A leitura da fluorescência foi realizada por citometria de fluxo. A padronização dos resultados é feita sobre a glicose de cultivo - 11,1 mM. $\mathrm{n}=3$ U.A. $=$ Unidades Arbitrárias. Em A: ${ }^{*} \mathrm{p}<0,05,{ }^{* * *} \mathrm{P}<0,001$ - Teste: One Way Anova - aplicado separadamente para cada curva, resultado na respectiva cor da curva. Em B: ${ }^{* * *} p<0,001$ - comparando glicose entre duas curvas. Two Way Anova para comparar conjuntamente as duas curvas. 
Enquanto os resultados com DHE foram consistentes, os resultados obtidos com Mitosox foram bastante inesperados, com diferenças inclusive entre a linhagem celular e as ilhotas. No caso da INS-1E parece haver um aumento da concentração de superóxido mitocondrial na presença de alta glicose. Não há diferença significativa entre os períodos de incubação, com as curvas praticamente idênticas, mas há diferença $(p<0,001)$ para o efeito da glicose. Em 48 horas, encontra-se uma tendência a um menor conteúdo de superóxido na presença de baixa glicose $(2,8 \mathrm{mM})$, mas não é estatisticamente relevante.

Já para as ilhotas as respostas foram diferentes não só com relação às células, mas também entre os tempos de tratamento. Em uma hora observa-se uma redução de conteúdo de acordo com o aumento do açúcar após $1 \mathrm{~h}$ de estímulo, enquanto que ao compararmos os diferentes tempos de incubação, há diminuição em baixa e alta glicose após $48 \mathrm{~h}$ de incubação. Entretanto, ao contrário da INS-1E, não há resultados estatisticamente significativos entre as diferentes concentrações de glicose em cada curva, sendo a influência preponderante em 48 h o tempo de incubação. Quando comparados os diferentes períodos com a mesma concentração de glicose encontramos diferença apenas em 2,8 mM de glicose em 48 horas. De qualquer modo, aparentemente há diferenças entre o conteúdo mitocondrial e total em reposta à glicose, já que nenhuma delas se comportou igual ao DHE, assumiu-se que provavelmente o acúmulo mitocondrial tenha uma dinâmica diferente a do citosol em resposta à glicose.

\subsection{Capacidade de redução da glutationa em resposta à glicose}

Após verificarmos o alto conteúdo de superóxido na presença de baixa glicose, decidimos avaliar a capacidade de redução da glutationa oxidada a reduzida através de um ensaio enzimático cinético de 3 horas com as células vivas. Previamente ao experimento, assim como nos ensaios anteriores, as células INS-1E foram incubadas com concentrações crescentes de glicose por 1 ou 48 horas. O resultado foi bastante interessante, pois há diferenças relevantes especialmente entre os tempos de incubação. Agudamente, não há diferenças significativas entre as concentrações de glicose, enquanto que a incubação mais longa, na presença de diferentes concentrações de glicose, mostra que quanto mais glicose disponível maior é a capacidade das células de produzirem glutationa reduzida (Figura 16). As concentrações de glicose em $48 \mathrm{~h}$ tem um efeito estatisticamente significativo, e as 
diferenças relevantes são entre alta glicose $(20 \mathrm{mM})$ e as concentrações mais baixas: $2,8 \mathrm{mM}$ $(p=0,002), 5,6 \mathrm{mM}(p=0,011)$ e $8,3 \mathrm{mM}(p=0,019)$.

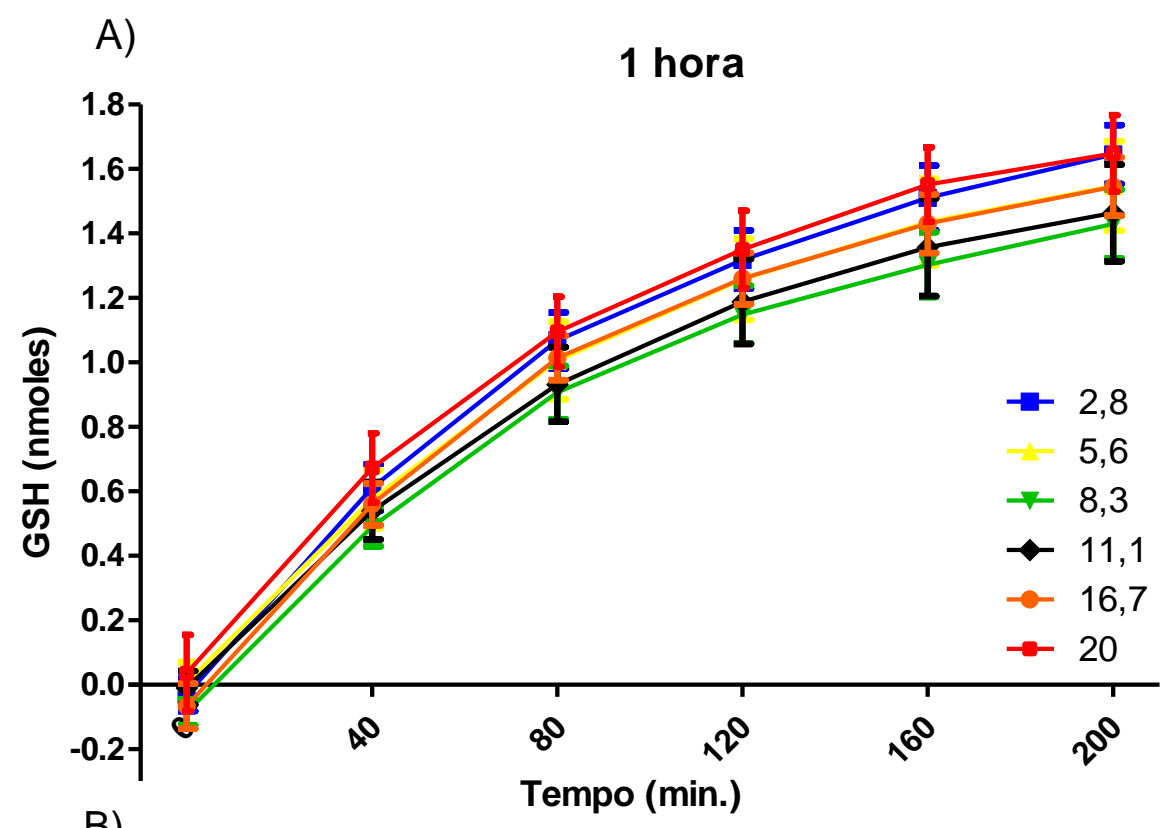

B)

48 horas

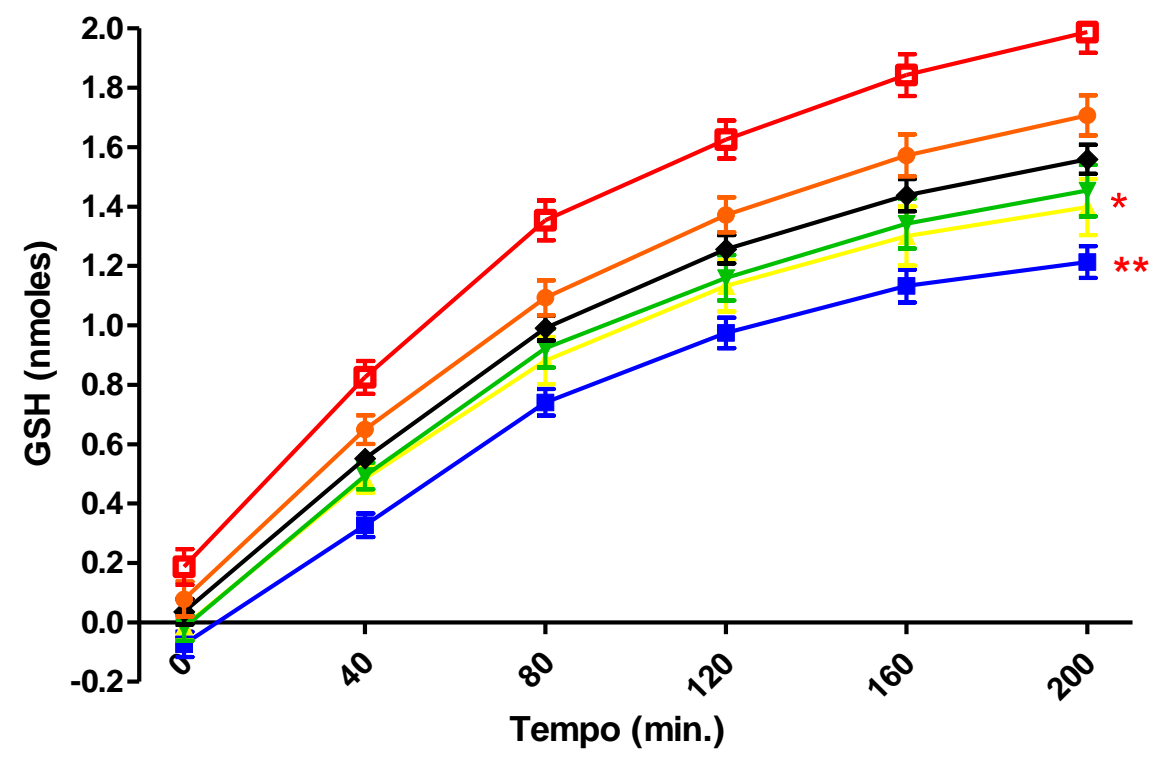

FIGURA 16: Capacidade de redução de GSSG à GSH em concentrações crescentes de glicose. As células INS-1E foram incubadas por 1 hora (A) ou 48 horas (B) após o qual foi utilizado o método do monochlorabamine com as células vivas $\mathrm{e}$ medidas de fluorescência a cada 40 minutos. Abreviações: GSSG: Glutationa oxidada; GSH.= Glutationa Reduzida. ${ }^{*} p<0,05,{ }^{* *} p<0,005$ em relação a 20 mM.

Apenas quando analisamos alta e baixa glicose, conseguimos ver o claramente o efeito da concentração de açúcar em cada um dos tempos de tratamento. Curiosamente, o 
que observamis é que a resposta à baixa e alta glicose em 1 hora de incubação é exatamente a mesma, enquanto que com 48 horas vemos uma diferença estatisticamente significativa entre ambas após a segunda dosagem de fluorescência (40 minutos). Isso demonstra que na presença de baixa glicose a capacidade de reduzir GSSG à GSH está bastante comprometida após 48 horas de incubação. Já para alta glicose vemos um aumento nesta capacidade. Assim, foi detectado efeito da interação entre concentração de glicose versus tempo versus experimento $(p=0,003)$ (Figura 17). Em resumo, a presença de elevada glicose aumenta a concentração de glutationa reduzida (GSH) após 48 horas de incubação.

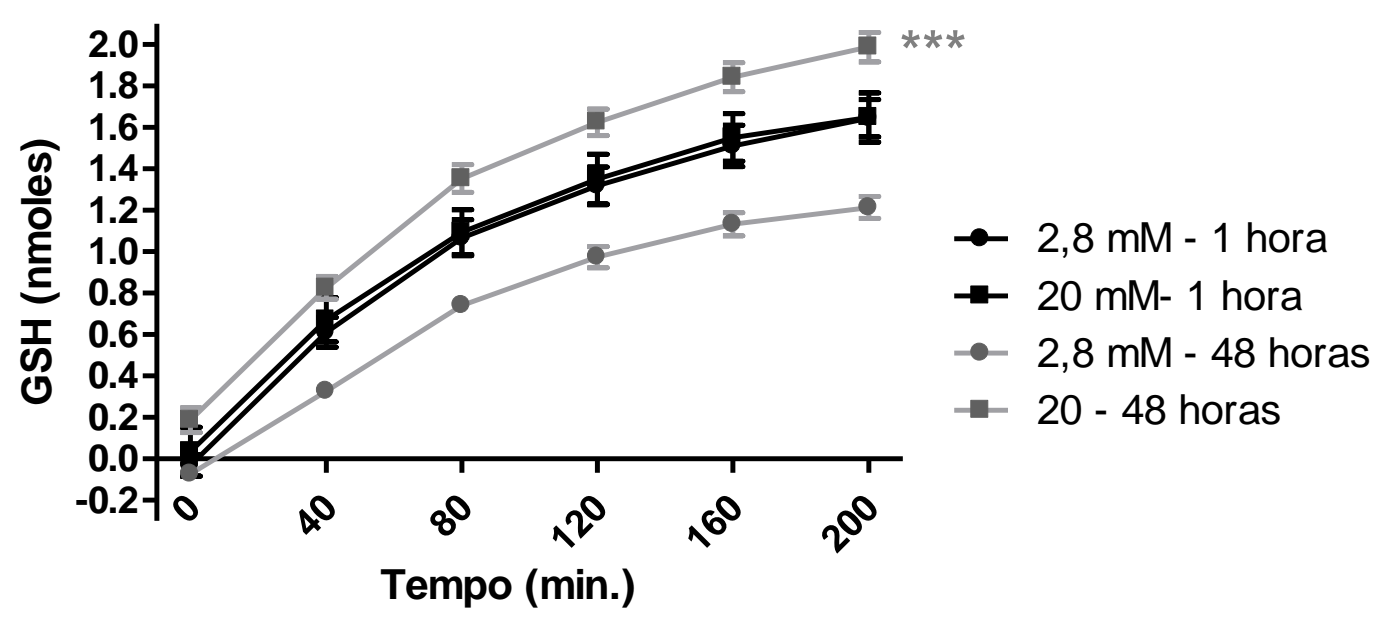

FIGURA 17: Comparação entre as curvas de redução de GSSG à GSH em alta e baixa glicose após 1 ou 48 horas de incubação. As células INS-1E foram incubadas por 1 hora ou 48 horas, após o qual foi utilizado o método do monochlorabamine com as células vivas e medidas de fluorescência a cada 40 minutos. Abreviações: GSSG GSH.= Glutationa Reduzida *** $p<0,005$ em relação a $2,8 \mathrm{mM}$ em $48 \mathrm{~h}$.

\subsection{Conteúdo de RNAm e proteína das enzimas antioxidantes e componentes da NADPH oxidase}

Não só a produção de EROs ou de moléculas antioxidantes como a GSH podem influenciar no estado redox celular, mas também as inúmeras enzimas antioxidantes tem um efeito relevante na homeostasia redox, assim como as proteínas componentes dos complexo enzimático NADPH oxidase. Sendo assim, avaliamos qual o efeito da incubação por $48 \mathrm{~h}$ com baixa e alta glicose sobre o conteúdo de RNA mensageiro (Tabela 3) e proteico de Nox2 e de algumas das enzimas antioxidantes encontradas em células eucarióticas. A maioria delas 
teve sua expressão de RNA mensageiro (RNAm) diminuído na presença de baixa glicose, com exceção de Sod2 e a glutationa redutase. Para os componentes da NADPH oxidase, Rac1 está diminuída, enquanto Nox2 está aumentada na presença de baixa glicose. As alterações encontradas na presença de alta glicose não foram significativas. De qualquer modo, a partir destes resultados podemos supor que a glicose, ou melhor, a falta dela, é capaz de modular a expressão do RNAm das enzimas antioxidantes e componentes da NADPH oxidase.

TABELA 3 - CONTEÚDo DE RNAM das enzimas antioxidantes e componentes da NADPH oxidase. As células INS-1E foram incubadas por 48 horas em baixa $(2,8 \mathrm{mM})$, basal ou controle $(11,1 \mathrm{mM})$ e alta glicose $(20 \mathrm{mM})$. Dosagem feita por PCR em tempo real. $n=3-p<0,05$ ou $p<0,005$.

\begin{tabular}{|c|c|c|c|}
\hline & $2.8 \mathrm{MM}$ & $11 \mathrm{MM}$ & $20 \mathrm{MM}$ \\
\hline RAC1 & $0,695 \pm 0,07^{*}$ & $1,025 \pm 0,1$ & $0,775 \pm 0,09$ \\
\hline GP91 $^{\text {PHOX }}$ & $1,652 \pm 0,24^{*}$ & $1,042 \pm 0,13$ & $0,918 \pm 0,16$ \\
\hline SOD1 & $0,738 \pm 0,06^{*}$ & $1,024 \pm 0,11$ & $0,895 \pm 0,09$ \\
\hline SOD2 & $0,845 \pm 014$ & $1,055 \pm 0,14$ & $0,895 \pm 0,17$ \\
\hline CATALASE & $0,695 \pm 0,08^{*}$ & $1,025 \pm 0,1$ & $0,775 \pm 0,081$ \\
\hline TIOREDOXINA & $0,667 \pm 0,05^{* *}$ & $1,013 \pm 0,07$ & $0,997 \pm 0,1$ \\
\hline GLUTATIONA REDUTASE & $0,93 \pm 0,1$ & $1,072 \pm 0,16$ & $1,228 \pm 0,09$ \\
\hline
\end{tabular}

Após verificarmos se a alta ou baixa glicose por 48 horas era capaz de alterar a expressão gênica, seguimos para avaliar se também havia alterações nas proteínas em questão. As respostas não seguiram um padrão como no caso do RNAm que diminuiu para a maioria das enzimas antioxidantes na presença de baixa glicose. Rac1 e Sod2 diminuíram na presença de alta glicose (Figura 18). Já a catalase e gp91 ${ }^{\text {phox }}$ diminuíram na presença de baixa glicose. Glutationa peroxidase (GPx) aumentou na presença de baixa glicose. A tiorredoxina e a Sod1 não tiveram sua expressão alterada em relação à glicose basal. 

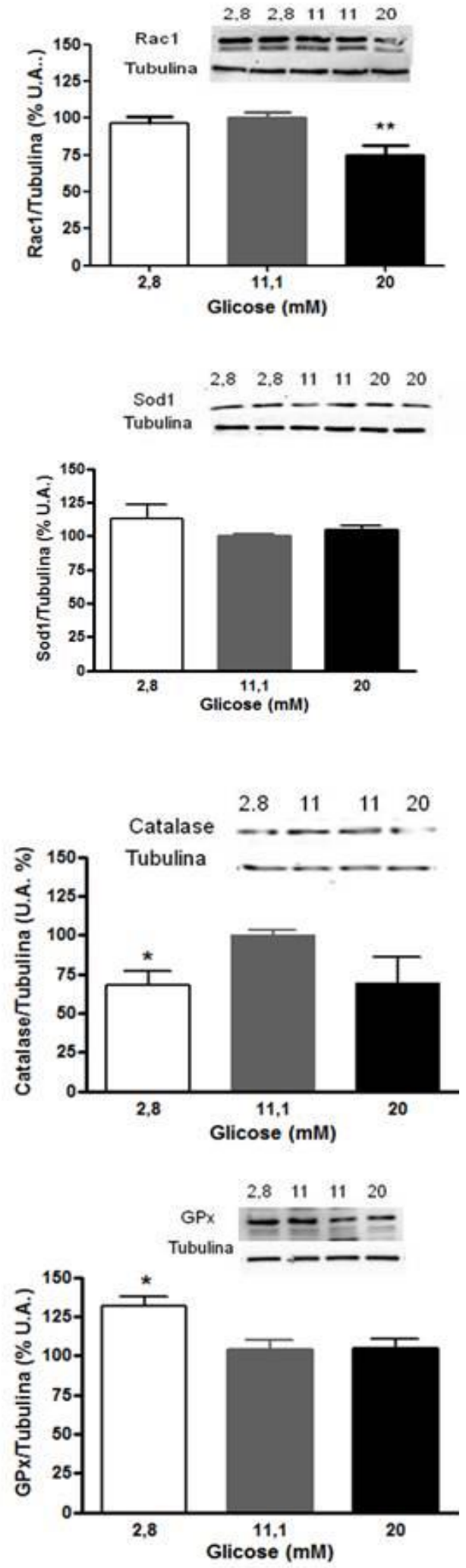
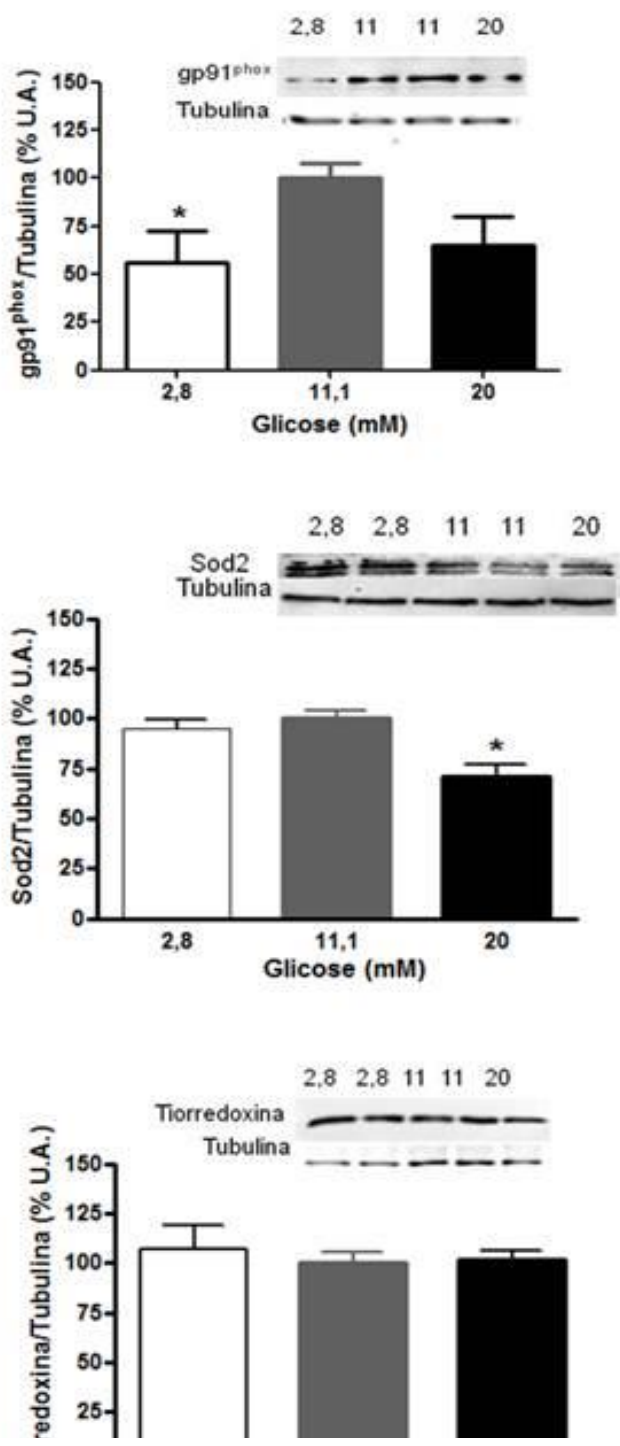

FIGURA 18: Expressão proteica das enzimas antioxidantes e de componentes do complexo NADPH oxidase. As imagens mostradas das bandas são representativas dos resultados obtidos de três a cinco experimentos independentes. Abreviações: GPx glutationa peroxidase; Sod - Superóxido dismutase; U.A. - Unidade Arbitrária. $n=3-5, * p<0,05$. 


\subsection{Morte e viabilidade celular}

Outro fator que foi avaliado foi se a mudança na concentração de glicose durante 48 horas também seria capaz de causar morte celular. Comparando com o basal as concentrações mais baixas foram mais letais que as altas tanto para as células INS-1E (Figura 19a) quanto para as ilhotas pancreáticas em cultura (Figura 19b).

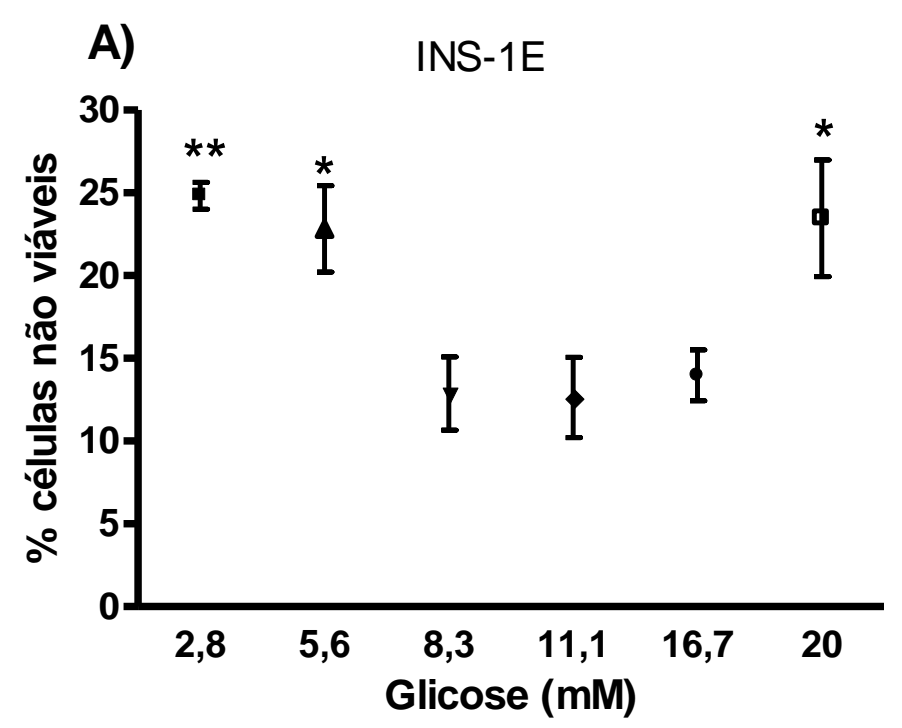

B)

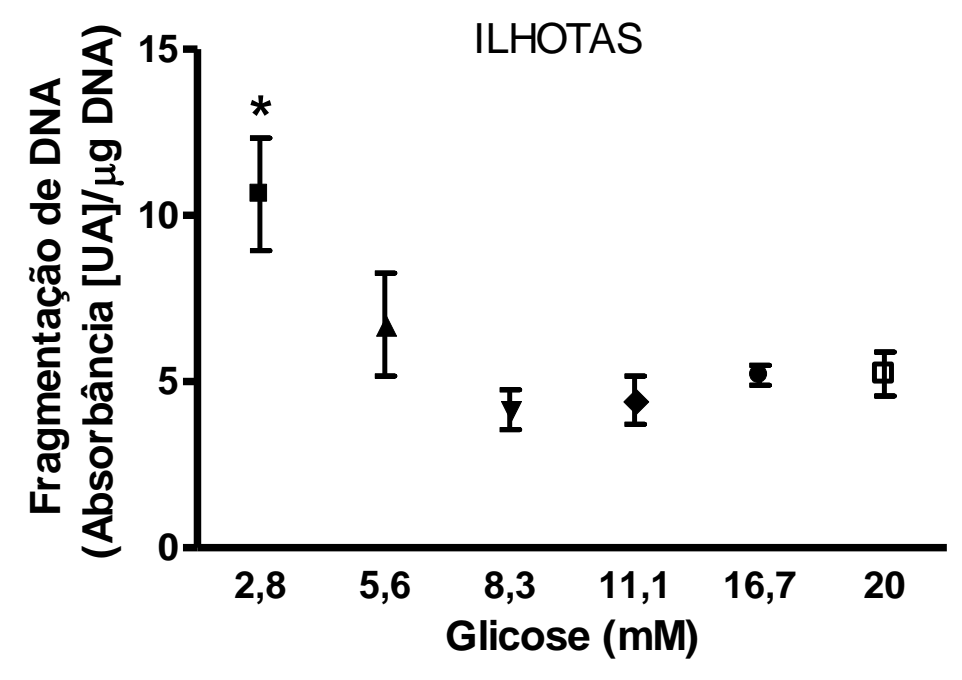

FIGURA 19: Morte celular após 48 horas de incubação em diferentes concentrações de glicose. A) Linhagem celular INS-1E (Dosagem por citometria de fluxo com o kit ViaCount ${ }^{\circledR}$ ). B) Ilhotas pancreáticas de rato isoladas (Dosagem por Elisa pelo Kit Cell Death $\left.{ }^{\circledR}\right)$. A padronização dos resultados é feita sobre a glicose de cultivo $-11,1 \mathrm{mM}$. $\mathrm{n}=3-5 ;$ U.A. = Unidades Arbitrárias. $\mathrm{p}<0,05,{ }^{* *} \mathrm{P}<0,005$. 
O teste do MTT (3-(4,5-dimetiltiazol-2yl)-2,5-difenil brometo de tetrazolina) é amplamente utilizado para se avaliar a viabilidade celular. O resultado após 24 horas de incubação da célula INS 832/13 incubada com diferentes concentrações de glicose: baixa (2,8 $\mathrm{mM})$, basal $(11,1 \mathrm{mM})$ e alta $(20 \mathrm{mM})$ mostrou que a viabilidade das células na presença de alta glicose é um pouco maior que a das células em estado basal e significativamente menor na presença de baixa glicose (Figura 20).

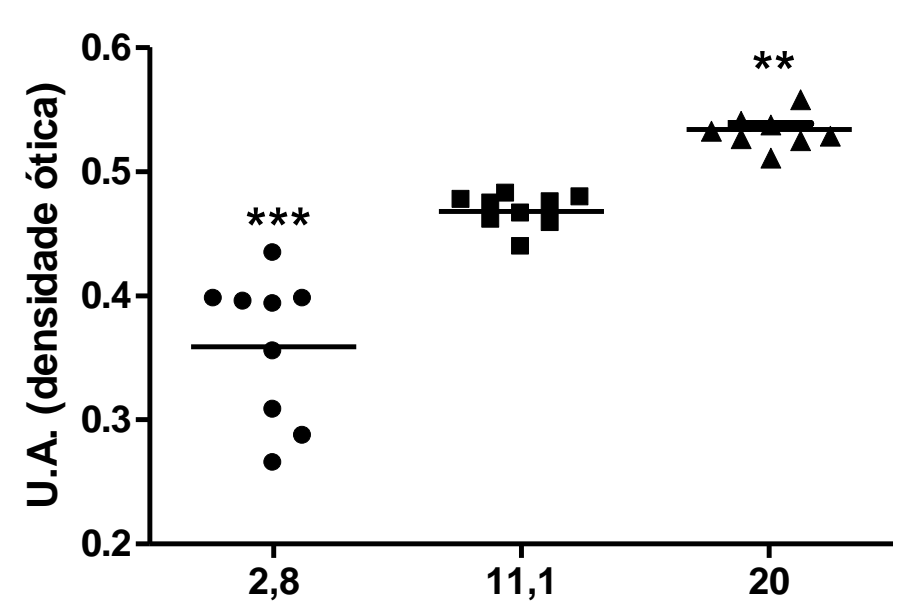

FIGURA 20: Ensaio de viabilidade celular (MTT) em células INS 832/13 incubadas por 24 horas em diferentes concentrações de glicose (2,8; 11,1 e $20 \mathrm{mM})$. Todos os tratamentos foram comparados à glicose basal $(11,1 \mathrm{mM})$. UA= Unidades Arbitrárias, $\mathrm{n}=3, * * \mathrm{p}<0,005 e^{* * *} \mathrm{p}<0,0001$.

\subsection{Secreção de insulina estimulada por glicose com inibição da Sod1}

O fato das ilhotas pancreáticas apresentarem não só sistemas antioxidantes, mas também sistemas geradores de espécies reativas de oxigênio denota a existência de mecanismos fisiológicos envolvendo as mesmas. A principal atividade desta célula é a secreção de insulina em resposta à glicemia. Através da inibição farmacológica da enzima Sod1, que tem uma função dual na homeostase redox, por ter uma atuação tanto no sistema antioxidante quanto estimulando a produção de superóxido através da interação com Rac1, tentamos observar se haveria alguma alteração na secreção de insulina estimulada por glicose. O inibidor usado foi o DETC (dietilditiocarbamato). Anteriormente ao uso do fármaco 
realizamos um teste de viabilidade com incubação overnight, para escolher a concentração do inibidor em meio RPMI com baixo soro fetal bovino e glicose (Figura 21a) ou meio RPMI normal (Figura 21b). O meio com baixo soro e glicose foi escolhido por apresentar menor diferença entre o tratamento controle e com DETC e para estimular a resposta secretória. $\mathrm{O}$ que observamos é que utilizando o inibidor não só houve uma marcante diminuição na secreção na presença de alta glicose (Figura 22a), como uma drástica diminuição no conteúdo de insulina (Figura 22b).

A)

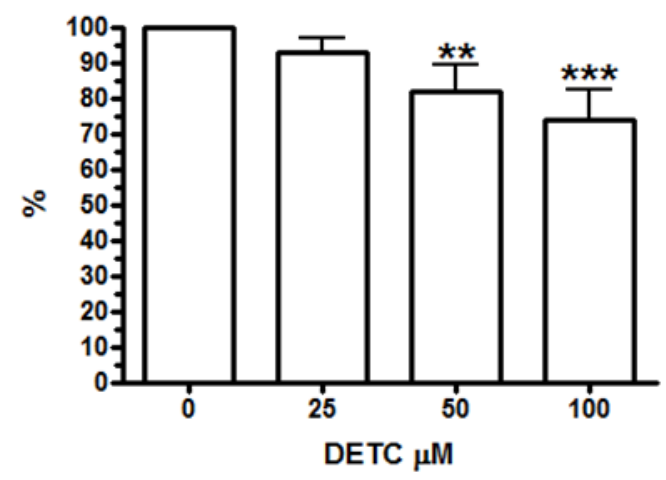

B)

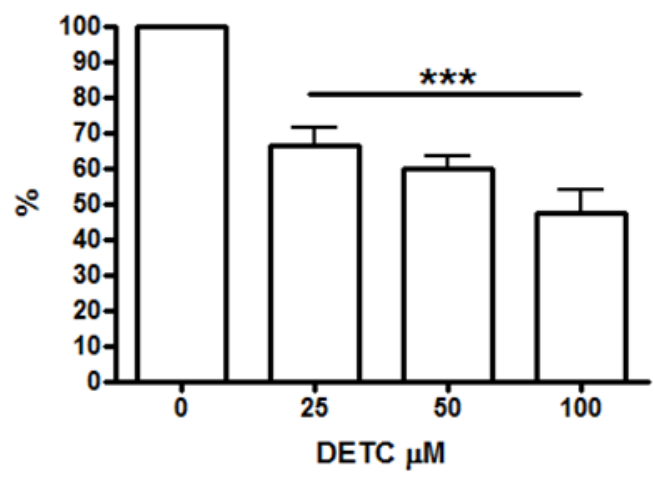

FIGURA 21: Teste de citoxicidade MTT com diferentes concentrações de DETC. Os resultados são expressos como porcentagem de viabilidade em relação ao controle. Foram utilizadas as concentrações de 25, 50 ou $100 \mu \mathrm{M}$ de DETC. A) Meio RPMI com baixa glicose $(2,8 \mathrm{mM})$ e baixo soro $(2,5 \%) ; \mathrm{B}) \mathrm{RPMI}$ norma $(11,1 \mathrm{mM}$ e $5 \%) .{ }^{* *} \mathrm{p}<0,01 ;{ }^{* * *}$ $p<0,001$.

A)

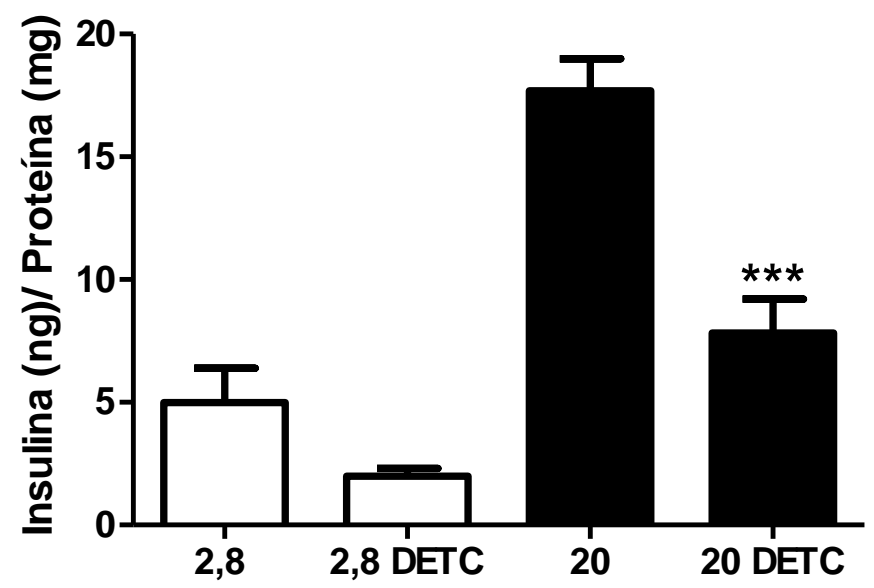


B)

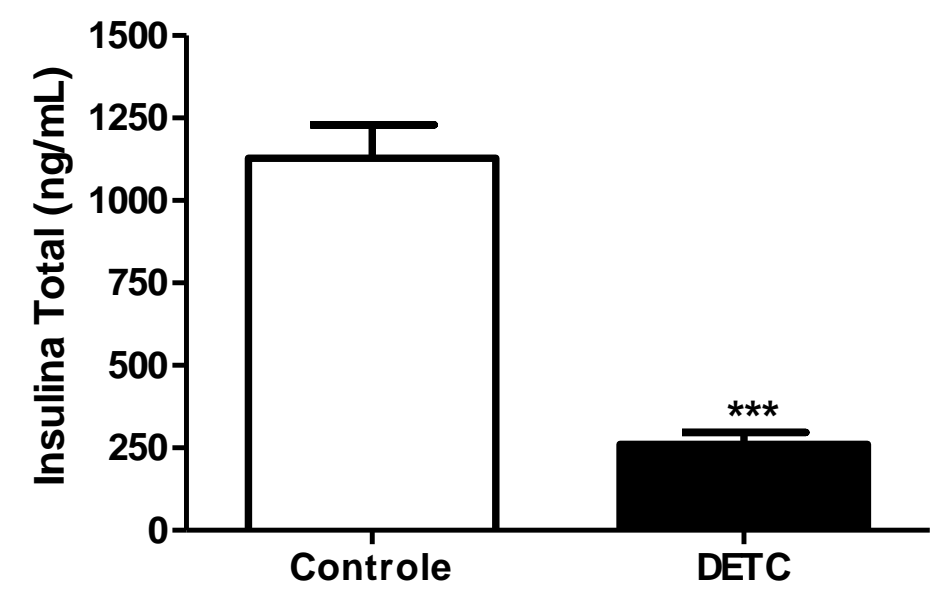

FIGURA 22 - Secreção de insulina na presença de baixa e alta glicose com ou sem DETC (A) e Conteúdo total de Insulina (B). Abreviações: 2.8: 2,8 mM de glicose; 20: $20 \mathrm{mM}$ de glicose; $C=$ controle. Ambos foram dosados pelo método elisa. ${ }^{*} p<0,05, * * * p<0,001$.

\subsection{Interação Rac1/Sod1}

A interação entre Rac1/Sod1 descrita inicialmente em células gliais como mais um mecanismo de controle na produção de superóxido via NADPH oxidase, foi observada nas células INS 832-13, como é demonstrado nas micrografias obtidas através dos experimentos de imunofluorescência, em que a marcação em verde representa Sod1 e em vermelho a Rac1, enquanto o núcleo está marcado em azul por DAPI (Figura 23). Na presença de alta glicose $(20 \mathrm{mM})$ observamos a presença de ambos componentes na membrana apresentando colocalização, com coloração amarela pela mistura de cores, mostrando que a interação entre estas proteínas aumentada nesta condição.

Também demonstramos a interação através da técnica de centrifugação diferencial do extrato das células INS-1E, obtendo assim as frações de membrana e citosol que posteriormente foram avaliadas por immunobloting (Figura 24). Sabe-se que a Rac1 quando ativada migra para a membrana, porém a Sod1, proteína citosólica, não é esperada sua presença na fração de membrana. As bandas que obtivemos de Sod1 na membrana, consequentemente, se devem à interação física entre as duas proteínas. 
Resultados
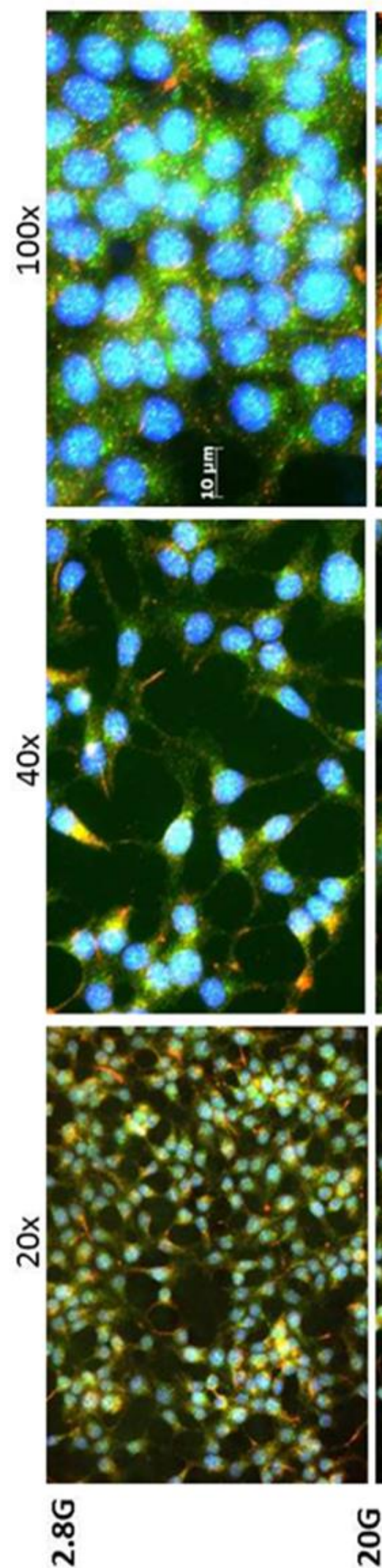
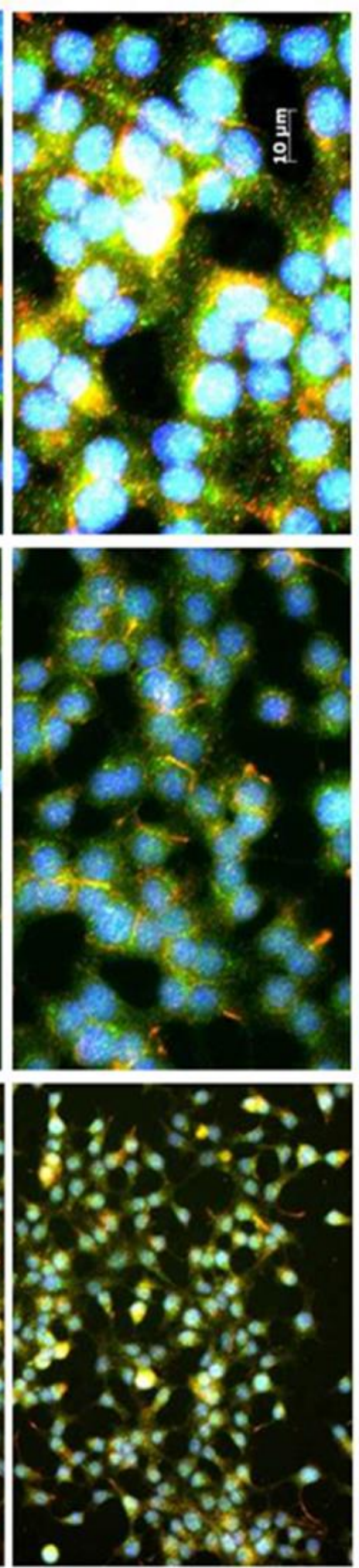

¿

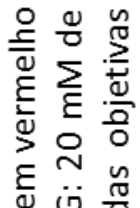

\&

守

นิ๊

음

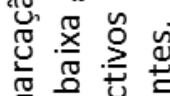

है

กั

흔 䏠 웡

$\geq$ 음.

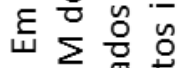

ब ह छ

ठั. $\infty$.

믐

ชั

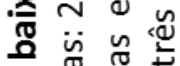

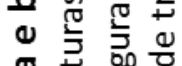

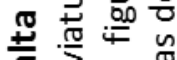

ह

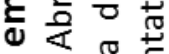

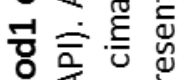

농

ᄀᄀ 웡

ॠ

0 $匚$ 票

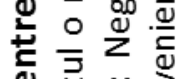

议

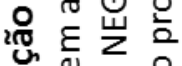

ชั ब

겅

으 응

후 음

인

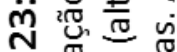

진

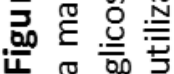




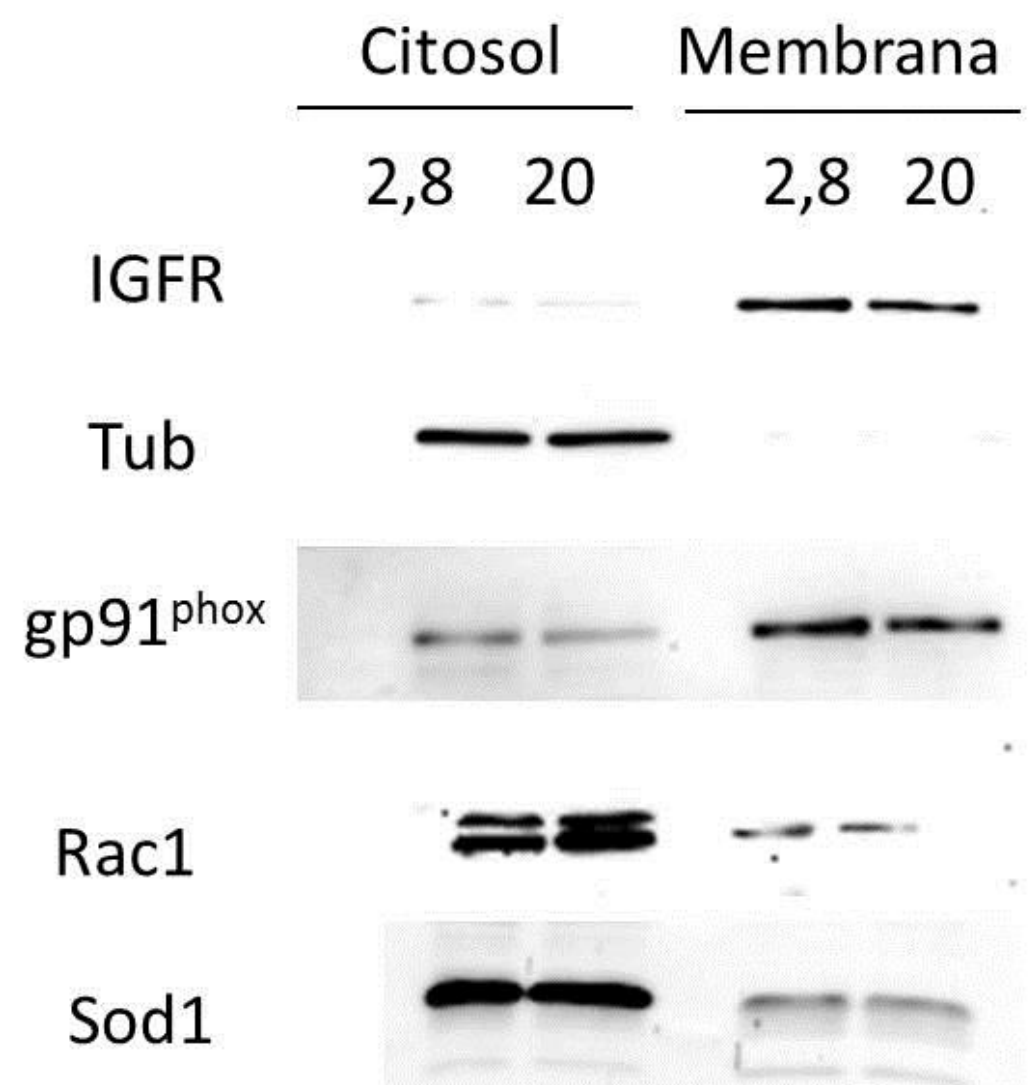

FIGURA 24: Immunobloting das frações de Membrana e Citosol de INS-1E. Bandas representativas de 4 experimentos independentes mostrando a presença de Sod1 e Rac1 na fração de membrana após 15 minutos de incubação com baixa $(2,8 \mathrm{mM})$ e alta glicose (20 mM). Abreviações: IGFR: Insulin-like growth factor 1 receptor - marcador da fração de membrana; Tub: Tubulina - marcador da fração citosólica; Sod1: Superóxido dismutase 1; Rac1: Ras-related C3 botulinum toxin substrate 1.

\subsection{Redoxossomas}

Nos últimos anos tem sido reportado por diferentes grupos o aparecimento de organelas vesiculares, endossomas, contendo proteínas da família Nox e produzindo em seu interior superóxido, sendo nomeado em uma revisão por Redoxossomas (OAKLEY, ABBOTT, et al., 2009). Acredita-se que sua função seja primordialmente de gerar uma sinalização localizada e segura. Na tentativa de demonstrar pela primeira vez sua existência em células beta pancreáticas utilizamos a sonda OxyBurst ${ }^{\circledR}$, utilizada classicamente para marcar os fagossomas durante o burst oxidativo de células imunes. Os testes com o controle positivo, 
neutrófilos estimulados por zymozan opsinizado, mostraram que a sonda estava funcionando perfeitamente, com a marcação em verde sinalizando a produção de EROs após o neutrófilo fagocitar a levedura (Figura 25a). Entretanto, para as células INS-1E, foram tentados vários protocolos, não só através da microscopia, mas também por citometria de fluxo. Inicialmente utilizamos a glicose como possível estímulo, já que este é o estímulo mais importante para este tipo celular. Posteriormente também testamos as citocinas, como o TNF- $\alpha$ ou IL-1 $\beta$, já que foram utilizados nos experimentos com células endoteliais como estimuladores para a formação dessas vesículas oxidativas, porém não obtivemos sucesso em nenhuma tentativa, apenas observamos autofluorescência verde (Figura 25b).
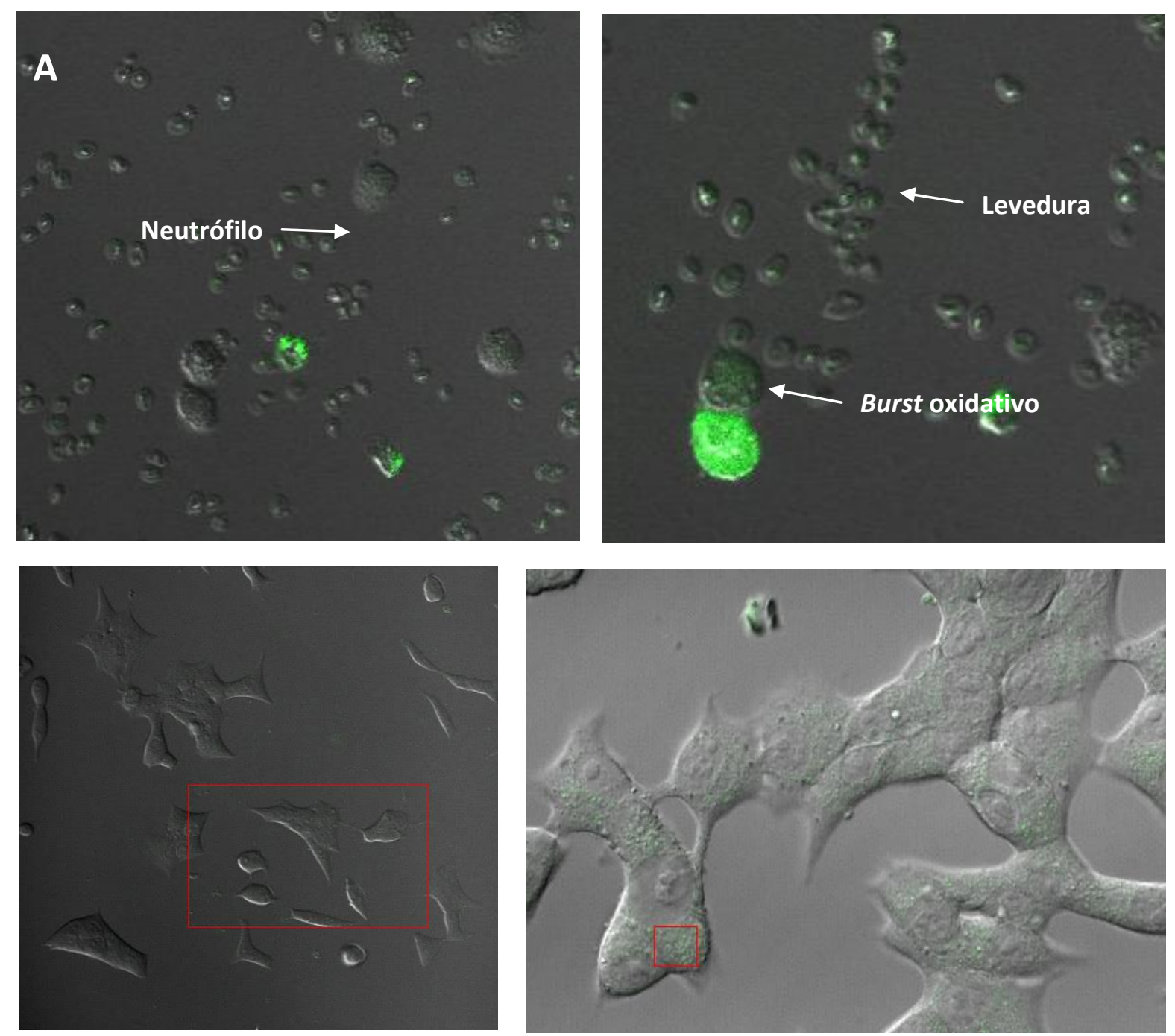

FIGURA 25 - Testes com a sonda Oxybursty ${ }^{\circledR}$ em neutrófilos (A) e céluas INS-1E (B). Os testes com a sonda para marcar fagossomos durante o burst oxidativo após neutrófilos fagocitarem leveduras, usado como controle positivo (a), não mostrou a formação de redoxossomas em células beta pancreáticas, apenas autofluorescência no verde (b). 


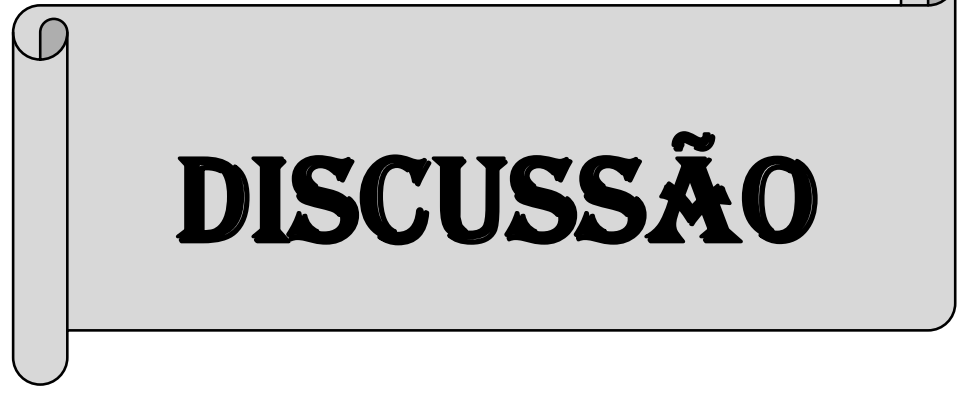




\section{DISCUSSÃo}

Apesar da ideia inicial de que as espécies reativas de oxigênio pudessem ser sinalizadores celulares datar dos anos 70 do século passado, é recente a aceitação e consolidação deste fato pela comunidade científica. Entretanto, nos últimos anos rapidamente se acumularam crescentes evidências deste papel sinalizador de EROs. Algumas das principais espécies reativas de oxigênio em sistemas biológicos são os radicais de oxigênio (dentre os quais está o ânion superóxido), o peróxido de hidrogênio, o peroxinitrito e o óxido nítrico (HORDIJK, 2006).

Para as células beta pancreáticas, há grande discussão acerca da importância e função das EROs, especialmente do óxido nítrico, superóxido e do peróxido de hidrogênio. Alguns trabalhos as relacionam tanto à modulação do processo de secreção de insulina quanto ao processo de morte celular por estresse oxidativo, ou seja, tanto a mecanismos fisiológicos quanto fisiopatológicos (BEFFY et al., 2001; PI et al., 2007; MORGAN et al., 2009). Ainda sim, uma questão básica ainda precisa ser claramente respondida. Afinal, a glicose aumenta ou diminui o conteúdo de superóxido nas células beta pancreáticas?

A produção de superóxido e peróxido de hidrogênio em resposta à glicose é um ponto de discordância entre diferentes estudos. Inicialmente todas as pesquisas publicadas apontavam para aumento de superóxido e peróxido de hidrogênio na presença de alta glicose (BINDOKAS et al., 2003; KRAUSS et al., 2003; MORGAN et al., 2007; MORGAN et al., 2009). Existem dados inclusive de estudos in vivo, de animais que foram mantidos em clamp hiperglicêmico (20-22 mM) por 48 horas. Estes roedores apresentaram aumento de superóxido total e mitocondrial, mas decréscimo da resposta secretória a alta glicose (TANG et al., 2012). Ilhotas humanas incubadas 48 h com 30 mM de glicose também apresentaram aumento de EROs (SYED et al., 2011).

Sob esta perspectiva era esperado que encontrássemos aumento de superóxido na presença de alta glicose, pois tal resultado não foi só visto em células beta pancreáticas, mas é bem estabelecido para outros tipos celulares como as células endoteliais (FUNK et al., 2012). Entretanto, nossos experimentos realizados após 1 hora de incubação, mostram que o conteúdo de superóxido celular é maior em concentrações menores de glicose e diminui paulatinamente com o aumento da mesma. Alterando o tempo de incubação para 48 horas, 
vemos essa diferença crescer consideravelmente, com o valor na glicose mais baixa $(2,8$ $\mathrm{mM}$ ) subir para $300 \%$ a mais que o basal (11,1 mM - sempre padronizado como $100 \%)$. Esses resultados foram observados tanto para a linhagem celular INS-1E quanto para as ilhotas pancreáticas de rato em cultura. Outros grupos além do nosso encontraram resultado semelhante e reportaram a baixa produção de EROs na presença de alta glicose (MARTENS et al., 2005; SARRE et al., 2012). Mas afinal, por qual razão encontramos resultados tão diferentes?

A discrepância entre os resultados encontrados reside provavelmente nos métodos utilizados. Os métodos mais usados nos artigos citados envolvem as sondas DCF (diacetato 2'7'-diclorodiidrofluoresceína - $\mathrm{H}_{2}$ DCFDA) e hidroetidina (DHE) ou o teste do NBT (Nitroazul de tetrazólio). Tanto o teste do NBT quanto a sonda DCF são métodos inapropiados, pois se baseiam em oxidações que são bastante inespecíficas. Atualmente, há um grande esforço na obtenção de novas metodologias para medição de EROs, devido à alta inespecificidade das sondas e à dificuldade de se medir espécies químicas tão lábeis.

A maioria dos trabalhos usa a DHE, ainda tida como uma sonda fluorescente específica para o superóxido. Porém, ainda não é uma sonda perfeita. Na verdade, o produto da reação com este ânion gera o 2-hidroxietídio. Além dele há também a formação do etídio, que é produto da oxidação da DHE com outros oxidantes. O problema é que ambos estão no mesmo espectro de fluorescência, sendo quantificados juntos (KALYANARAMAN et al., 2014). Assim, o uso de microscopia fluorescente, empregado em muitos trabalhos mais antigos, não é o método mais indicado para tal avaliação e provavelmente superestima os resultados na presença de alta glicose citados. A citometria de fluxo, que considera milhares de eventos em cada contagem, é melhor por ser quantitativo, mas também possui a mesma limitação. Os laboratórios que usam esta técnica encontraram o resultado oposto, mais superóxido na presença de baixa glicose. Os padrões ouro atualmente são a avaliação da DHE via HPLC, que separa o etídio do 2-hidroxietídio, e a espectroscopia de ressonância paramagnética. Essas técnicas são menos usadas, devido à sua maior complexidade e custo.

Outra questão pertinente em relação ao superóxido, maior na presença de baixa glicose, é sobre a origem do mesmo. Considerando que as duas fontes principais são a cadeia de transporte de elétrons mitocondrial e a NADPH oxidase, utilizamos duas abordagens diferentes para essa questão. Para o complexo enzimático de Nox2, usamos o 
inibidor de Tiam1, NSC23766. Tiam1 é o fator de troca de GDP (GEF) para Rac1 em ilhotas pancreáticas (VELUTHAKAL et al., 2009). Este composto foi selecionado por Gao e equipe (2004) através de uma busca virtual de substâncias químicas que continham estrutura para encaixe numa fenda da superfície de Rac1, sabidamente envolvida na especificidade de interação entre Rac e os GEFs. NSC23766 foi o mais efetivo em inibir a ativação de Rac1 (ligação ao GTP) através do impedimento da interação entre Rac1 e o GEF Tiam 1 e o GEF Trio. A inibição ocorreu de maneira dose-dependente, sendo que para experimentos de pull down uma inibição de $50 \%$ foi atingida com a concentração de $50 \mu \mathrm{M}$. A inibição também não interfere com outra Rho GTPases próximas como Cdc42 ou RhoA, seus respectivos GEFs, intersectina e PDZ-RhoGEF, e de outras proteínas que interagem com Rac1 (GAO et al., 2004).

Assim, indiretamente, o NSC23766 é uma maneira específica de inibir Tiam1 e consequentemente Rac1, que inativa a produção de superóxido via NADPH oxidase. Com $100 \mu \mathrm{M}$, maior concentração usada, observamos diminuição de $40 \%$ tanto na presença de baixa quanto na presença de alta glicose, o que aponta para a maior contribuição do sistema gerador de superóxido mitocondrial em ambos os casos. $O$ experimento seguinte em que foi usado $0 \mathrm{mM}$ de glicose e $2,8 \mathrm{mM}$ gerou um resultado muito curioso, pois além do conteúdo de superóxido ser ainda maior na ausência de glicose, não há inibição alguma com o uso de NSC23766.

Explicações plausíveis para tal fenômeno podem envolver as concentrações de $\mathrm{NAD}(\mathrm{P}) \mathrm{H}, \mathrm{ATP}$ e a maior contribuição da mitocôndria na geração de EROs nas células beta pancreáticas privadas de glicose. Trabalhos anteriores mostram que não só a concentração de $N A D(P) H$ é reduzida na ausência de glicose em células beta pancreáticas, mas também a de ATP (DETIMARY et al., 1998; MARTENS et al., 2005). Além disso, a ativação sustentada da NADPH oxidase pode levar à depleção de NADPH (GAO; MANN, 2009). A geração de superóxido é máxima entre 0-1 mM de glicose (SARRE et al., 2012). É possível que com a diminuição do agente redutor, o sistema NADPH oxidase já esteja inibido, enquanto o sistema mitocondrial aumente ainda mais sua atividade geradora de EROs.

A produção de superóxido mitocondrial avaliada pela sonda MitoSox ${ }^{\circledR}$, DHE com um tag direcionador para a mitocôndria, não apresentou respostas conclusivas. As respostas entre INS-1E e ilhotas pancreáticas foram diferentes, na primeira indicando aumento de 
produção, enquanto na última, após 1 hora de estímulo, mostrou diminuição. Outro estudo mostra que na presença de baixa glicose há um rápido aumento na produção de superóxido. Como este aumento só foi inibido pela rotenona e na presença de baixa glicose a atividade da aconitase estava reduzida (sinal de estresse oxidativo mitocondrial), a produção desta espécie reativa foi creditada à mitocôndria, especificamente ao complexo I (SARRE et al., 2012). Pela magnitude do conteúdo de superóxido encontrado em ausência ou baixa glicose, realmente a cadeia mitocondrial deve produzir alta quantidade de superóxido, como visto em 1 hora de incubação com 2,8 mM de glicose. Em 48 horas, o que pode ter ocorrido é a difusão do superóxido formado para o citosol, pois há relatos deste fenômeno (WALLACE et al., 2004; WAYPA et al., 2013). Outra possibilidade seria que a incubação na presença de alta glicose das ilhotas pancreáticas ative o sistema antioxidante mitocondrial, diminuindo a concentração de superóxido presente.

Não é de se surpreender que ambos os sistemas geradores estejam ativos nas mesmas condições e ambos contribuam na produção de superóxido. Alguns grupos tem apontado a ocorrência de crosstalk entre mitocôndria e NADPH oxidase em diferentes tipos celulares (leucócitos, células endoteliais e tumorais) e condições (hipóxia, envelhecimento, hiperglicemia, jejum, entre outras) e sua participação em mecanismos fisiopatológicos (DIKALOV, 2011; GRAHAM et al., 2012; KRÖLLER-SCHÖN et al., 2014; SCHULZ et al., 2014). Então é bastante plausível que na presença de baixa glicose ocorra um aumento total da produção de EROs via mitocôndria e complexo NADPH oxidase nas células beta pancreáticas. Mas não podemos apenas nos ater somente à produção de EROs, pois na equação complexa que define o estado redox dos compartimentos celulares não se pode apenas considerar a produção de EROs em si, mas também a contrapartida antioxidante .

A influência da glicose no ambiente redox aparentemente está ligada à concetração de $\mathrm{NAD}(\mathrm{P}) \mathrm{H}$ na célula beta pancreática. O grupo de Martens observou que a produção de superóxido celular é variável entre diferentes grupos de células. E essas células são também metabolicamente diferentes, podendo ser mais ou menos responsivas à glicose. As mais responsivas apresentam maior concentração de $\mathrm{NAD}(\mathrm{P}) \mathrm{H}$, que ao contrário do superóxido, são maiores quanto maior a concentração de glicose (MARTENS et al., 2005). O NADPH, mais conhecido por sua participação na via metabólica, atua também como antioxidante tanto 
diretamente reagindo com EROs, quanto ajudando na reciclagem de antioxidantes como a glutationa reduzida (KIRSCH; DE GROOT, 2001).

Desde a década de 1980 é divulgado que as ilhotas pancreáticas possuem baixa defesa antioxidante quando comparada com outros tecidos. A primeira citação a este fato se deu num artigo de Grankvist e colegas de 1981 que mostraram que a atividade das enzimas antioxidantes glutationa peroxidase (GPx), Sod1, Sod2 e catalase era bem menor no pâncreas endócrino que em outros tecidos (GRANKVIST et al., 1981). Em 1996 é mais uma vez confirmada essa hipótese pelo grupo do professor Lenzen, que demonstrou que a expressão de RNAm destas enzimas era bem menor que em outros tecidos como o fígado, rim e o cérebro. As ilhotas, em relação ao fígado, apresentam apenas $15 \%$ de GPx, $38 \%$ de $\mathrm{Cu} / \mathrm{Zn}$-Sod, 30 \% de Mn-Sod e nenhuma expressão de catalase (LENZEN et al., 1996). 0 mesmo foi demonstrado em seguida para a linhagem de células beta pancreáticas RINm5F (TIEDGE et al., 1997).

Entretanto, atualmente se sabe que há um contraponto nesta visão, pois as ilhotas pancreáticas são ricas em outro tipo de antioxidantes: tiorredoxinas (TRX), tiorredoxinas reductases e sistemas redox acoplados à glutationa, como glutationa redutase, várias isoformas de glutarredoxinas (GRXs) e peroxirredoxinas (IVARSSON et al., 2005; DAMMEYER; ARNÉR, 2011). A tiorredoxina redutase usa os elétrons do NADPH para reciclar a TRX oxidada a reduzida. Da mesma maneira, as glutarredoxinas dependem diretamente da glutationa para sua regeneração (HOLMGREN, 2000). Outras moléculas importantes na proteção dos danos oxidativos para as células beta são ácido úrico, ascorbato, $\alpha$-tocoferol e com especial destaque a glutationa (JEŽEK et al., 2012).

A glutationa é um tripeptídeo (glutamina-cisteína-glicina), e é a molécula de grupamento tiol de menor peso molecular presente nas células, mas a principal responsável pela defesa de agentes causadores de estresse oxidativo (KAMENCIC et al., 2000). Além disso, possui papel importante na detoxificação de xenobióticos, remoção de hidroperóxidos e na manutenção do estado redox de proteínas com grupamentos sulfidrila (AKERBOOM; SIES, 1981). Cerca de $90 \%$ da glutationa nas células está presente na forma reduzida (GSH) e o restante em sua forma oxidada (GSSG). A razão GSH/GSSG tem sido usada como um dos indicativos de estresse oxidativo, inclusive em plasma humano (JONES, 2006). Assim, 
podemos considerar o conteúdo de GSH como um bom parâmetro para avaliar o estado redox celular.

A glicose também é capaz de alterar o conteúdo de GSH nas células beta pancreáticas. Num ensaio cinético para avaliar as concentrações de glutationa reduzida in vivo nas células INS-1E com apenas 1 hora de incubação não vemos diferenças significativas entre as concentrações de glicose. As curvas de $2,8 \mathrm{mM}$ e $20 \mathrm{mM}$ são praticamente idênticas demonstrando que as células tem a mesma concentração final de GSH. Porém, quando comparamos com os resultados após 48 horas de incubação, observamos que as concentrações de glicose maiores têm um conteúdo final maior de glutationa reduzida, enquanto as glicoses mais baixas têm conteúdos mais baixos, com diferença significativa entre 2,8 mM e 5,6 mM com 20 mM. Comparando a incubação aguda com a crônica vemos que o conteúdo ou a capacidade de reduzir a glutationa cai em 2,8 mM, enquanto aumenta em $20 \mathrm{mM}$.

Este resultado pode ser devido a alteração na concentração de NADPH ocasionada pela glicose, como também pode ser que acompanhe as mudanças na atividade da glutationa reductase, enzima responsável pela reciclagem GSSG/GSH, e também na taxa de metabolização do tripeptídeo. Assim, não só o conteúdo de superóxido é maior na presença de baixa glicose como também o sistema antioxidante, pode estar diminuído em conteúdo/atividade. Em 48 horas, o aumento exacerbado do superóxido em 2,8 mM pode advir da exaustão do sistema antioxidante, como exemplificado para GSH que apresenta uma menor concentração e redução na capacidade de reciclagem de GSSG.

Um trabalho recente em ilhotas pancreáticas mediu o efeito da glicose sobre a razão GSH/GSSG no citosol e na mitocôndria através de sondas redox-sensíveis específicas para medição do potencial redox da glutationa. Agudamente, a glicose aumenta o NAD(P)H e também a razão GSH/GSSG apenas na mitocôndria, enquanto o citosol permanece inalterado. O uso concomitante de antioxidantes não levou a alteração no padrão de resposta da glicose e por isso os autores acreditam que esta tenha mais relação com o aumento de disponibilidade de $\mathrm{NAD}(\mathrm{P}) \mathrm{H}$ do que à ação de EROs na razão GSH/GSSG (TAKAHASH et al., 2014). Entretanto, estas análises foram feitas na mitocôndria, de modo dinâmico em não em incubações crônicas de glicose. Nossos experimentos, que envolveram um teste menos sensível e com tempos maiores de incubação, não identificaram diferenças 
em 1 hora de incubação, mas também indicaram um aumento de GSH com a elevação da glicose após estímulo de 48 horas.

A análise dos conteúdos de RNAm e proteicos das proteínas antioxidantes apontou principalmente para a diminuição da expressão das mesmas na presença de baixa glicose em relação à basal. Das enzimas analisadas apenas a glutationa redutase e Sod2 não mudaram significativamente a expressão de RNAm, enquanto Sod1, catalase e tiorredoxina diminuíram. Já para o conteúdo proteico apenas a catalase estava diminuída na presença de baixa glicose, enquanto a GPx estava aumentada, Sod1 e tiorredoxina inalteradas e Sod2 aumentada na presença de alta glicose. Os resultados incongruentes entre expressão gênica e proteica podem advir do fato da síntese proteica total estar consideravelmente diminuída na presença de baixa glicose nas células beta (BENSELLAM et al., 2009). Além disso, a baixa glicose também pode gerar a resposta integrada do estresse, o que altera o padrão de síntese proteica, diminuída globalmente, mas com aumento da tradução das proteínas reguladas por alguns fatores de transcrição (ELOUIL et al., 2007).

Resultados anteriores do nosso laboratório também mostram que ilhotas pancreáticas apresentam elevação da atividade de Sod1 com o aumento da concentração de glicose após estímulo agudo (OLIVEIRA et al., 1999). Análises de microarray mostram que na presença de baixa glicose as células beta passam a utilizar mais aminoácidos e proteínas como fonte de energia em detrimento da via glicolítica (WEBB et al., 2000). O sistema antioxidante depende em grande parte dos agentes redutores produzidos e como estes dependem do metabolismo e o mesmo está suprimido em condições com pouco nutrientes, é de se esperar que o sistema antioxidante fique prejudicado em reduzida glicose, como mostrado com o conteúdo de GSH. Assim, na presença de baixa glicose não só ocorre o aumento da geração de EROs como o sistema antioxidante está defasado, seja pela menor expressão ou atividade, e consequentemente reflete no maior conteúdo de superóxido especialmente após 48 horas de incubação, o que pode ser potencialmente danoso às células.

Avaliando a viabilidade celular das células cultivadas em 48 horas com concentrações diferentes de glicose observamos que a baixa glicose é potencialmente mais danosa para as ilhotas pancreáticas em cultura enquanto a linhagem celular INS-1E apresenta uma curva de morte em formato de $\mathrm{V}$, com perda de viabilidade na presença de baixa e alta glicose. Outros grupos encontraram resultados semelhantes (EFANOVA et al., 1998; BENSELLAM et 
al., 2009). O teste do MTT é amplamente utilizado para avaliar a citoxicidade de compostos. Seu mecanismo se baseia na ação das desidrogenases mitocondriais das células vivas que ao reduzirem o sal do MTT produzem os cristais de formazan (MOSMANN, 1983). Nas células beta pancreáticas ele também pode ser usado para avaliar o metabolismo glicolítico, pois há uma correlação direta entre este e a formação do formazan (JANJIC; WOLLHEIM, 1992). A incubação de 24 horas com glicose baixa, intermediária e alta, demonstrou então que quanto mais açúcar, mais ativa metabolicamente a célula está.

A ideia mais consensual atualmente ainda é a da glicotoxicidade associada ao estresse oxidativo resultante, e este possuindo papel central no desenvolvimento das diversas complicações do diabetes (ROCHETTE et al., 2014). Entretanto, a baixa glicose, ao menos in vitro, possui um efeito mais rápido do que a alta glicose e está associado ao desbalanço na produção/remoção de EROs. Em ilhotas pancreáticas cultivadas na presença de $30 \mathrm{mM}$ de glicose foi encontrado aumento significativo de morte celular apenas após uma semana, ainda assim a morte na presença de baixa glicose foi consideravelmente maior (DUPREZ et al., 2012). O uso de antioxidantes como o Mn-TBAP (manganese(III)tetrakis(4benzoicacid)porphyrin), foi capaz de reduzir a morte celular, mas não de restabelecer a resposta secretória após uma semana na presença de alta glicose (ROMA et al., 2012). Tal resultado indica que o estresse oxidativo pode ter um papel primordial para a morte celular, mas que os mecanismos moleculares envolvidos na glicotoxicidade vão além.

Nem todos os tipos celulares apresentam o mesmo comportamento quando expostos a diferentes concentrações de glicose. Células HEK, por exemplo, não alteram a razão GSH/GSSG com o aumento de glicose como as células beta (TAKAHASHI et al., 2014). O fenômeno da morte neuronal durante isquemia com baixo aporte de glicose e oxigênio é relacionado ao aumento do conteúdo de EROs (WANG et al., 2014). Numa linhagem de neuroblastoma o modelo de privação oxigênio/glicose mostrou ativação de NADPH oxidase, que quando inibida, diminui a morte neuronal (BESKE; JACKSON, 2012). Apesar da origem de tecidos embrionários distintos a similaridade entre células beta e células do sistema nervoso tem sido apontada há muito tempo. As células beta não só expressam marcadores neurais, mas também sabe-se que há neurônios hipotalâmicos responsivos à glicose, de maneira similar ao mecanismo que leva à secreção de insulina (YANG et al., 1999; MOUNTJOY; 
RUTTER, 2007; POUR; SARUC, 2011). A produção de EROs em situações de baixa glicose parece ser mais uma similaridade.

Algumas células de tumores como sarcomas e melanomas apresentam alterações em seu perfil metabólico, sendo muito dependentes do metabolismo glicolítico aeróbio. Estas células não só apresentam aumento de EROs na presença de baixa glicose, como produto do crosstalk entre mitocôndria e NADPH oxidase, mas também aumento de morte celular nesta condição (GRAHAM et al., 2012). Da mesma forma, as células beta pancreáticas possuem um perfil metabólico característico com praticamente toda a glicose metabolizada pela fosforilação oxidativa, um perfil similar ao chamado fenótipo Warburg, comum não só em células cancerígenas mas também em situações estressoras como a hipóxia (JEŽEK et al., 2012).

Apesar de observarmos em curto prazo que a baixa glicose gera maior conteúdo de superóxido, não quer dizer que in vivo o estresse oxidativo gerado pela hiperglicemia não ocorra. Animais diabéticos mantidos em hiperglicemia também apresentam estresse oxidativo, avaliado através de marcadores como o MDA (peroxidação lipídica), 8-hidroxiguanosina (dano oxidativo ao DNA) e pela quantificação de grupamentos carbonila (alteração nas proteínas), indicando aumento de EROs (MODAK et al., 2011). O estresse oxidativo e a ação deletéria que o excesso de glicose produz em longo prazo já foram associados com outros mecanismos relacionados à morte celular como o estresse de retículo, a ativação da via da apoptose intrínseca (BH3-mitocondrial) e ativação da proteína ligante de elementos responsivos à carboidratos (POUNGVARIN et al., 2012; WALI et al., 2014).

Para além da fisiopatologia, há também o papel fisiológico das EROs nas células beta pancreáticas. Ainda é muito controversa na literatura a participação dessas no processo de secreção de insulina. Alguns afirmam que o aumento de EROs gera estímulo da secreção, enquanto outros falam de uma inibição e terceiros alegam que não altera nada (PI et al., 2007; LELOUP et al., 2009; REBELATO et al., 2011; Ll et al., 2012; SARRE et al., 2012; LORTZ et al., 2013). Porém, cada vez mais os dados sugerem que ao alterar a homeostase redox celular, direta ou indiretamente, há modificações na secreção de insulina.

As células beta expostas à condição de hiperóxia não só tiveram aumento no conteúdo de EROs como apresentaram inibição da secreção de insulina estimulada por glicose (MA et 
al., 2014). A regulação redox realizada pela tiorredoxina e glutarredoxina foi considerada responsável pela ação moduladora do NADPH na exocitose dos grânulos de insulina durante a secreção estimulada por nutrientes (IVARSSON et al., 2005). Animais knockouts de GPx ou Sod1 apresentam inibição da secreção de insulina, assim como o knockout heterozigoto de Sod2 tratado com dieta rica em gordura (WANG et al., 2011; KANG et al., 2014). Já os de Nox2, Nox4 e Nox5 apresentam aumento (LI et al., 2012). Nossos resultados mostram que a inibição farmacológica de Sod1 por DETC não só diminui a resposta secretória a alta glicose, como também diminuiu o conteúdo total de insulina.

Sod1 não só é responsável apenas pela dismutação que converte o superóxido a peróxido de hidrogênio. Nas células gliais, Sod1 interage com Rac1 mantendo a produção de superóxido via Nox2 (HARRAZ et al., 2008). Também há o relato de que em células estelares hepáticas o mesmo mecanismo molecular está presente e mantém a atividade de Nox1 e Nox4 (AOYAMA et al., 2012). Em ambos os casos, a perda da interação acarretou em estresse oxidativo e progressão dos processos fisiopatológicos envolvidos na esclerose lateral amiotrófica e na fibrose hepático. Nas células beta pancreáticas verificamos a existência desta interação, que é maior na presença de alta glicose. Animais Zucker obesos, hiperlipidêmicos e hiperglicêmicos, apresentaram aumento de $\mathrm{p} 47^{\text {phox }}$ fosforilada e Rac1 ativada, o que sugere quem na presença de alta glicose realmente a atividade da NADPH oxidase está aumentada (SYED et al., 2011).

Tal resultado é esperado uma vez que esta ligação física só ocorre quando o meio está mais reduzido, o que aparenta ser o caso na presença de alta glicose. Esta interação parece ser controlada por uma alça de retroalimentação em que a própria atividade das enzimas gerando EROs que ao se acumular e ao oxidar o meio inibe a produção de superóxido. Além disso, a própria ativação de Rac1 por si só é afetada pelo ambiente redox, pois a presença de superóxido eleva em seiscentas vezes a velocidade de dissociação do GDP (HEO; CAMPBELL, 2005). Já a atividade da NADPH oxidase na presença de baixa glicose pode advir do feedback positivo entre esta e a cadeia mitocondrial, pois ao diminuir o conteúdo de EROs mitocondrial seja com antioxidantes ou inibidores, há inibição da atividade de Nox2 em células endoteliais (DIKALOV et al., 2014).

Além da descoberta da interação Rac1/Sod1, o grupo do professor John Engelhardt da Universidade de lowa, relatou a ocorrência de endossomas de sinalização redox que se 
formam em resposta a sinais oriundos de sinalização via receptores na membrana celular, como exemplo da citocina IL1- $\beta$ e TNF- $\alpha$ ou através de hipóxia seguida de reoxigenação. Nestes endossomos são recrutadas diversas proteínas como as componentes do complexo NADPH oxidase (incluindo Rac1), enzimas como Sod1 e peroxirredoxinas, canais de cloreto e sensores redox da atividade de Nox. A estes endossomas, o grupo propôs o nome de redoxossomas, que englobam um conjunto de proteínas capazes de processar EROs e de transmitir a sinalização destes para proteínas efetoras na membrana do endossoma que propagam para o citosol o sinal gerado culminando na sinalização do NF-kB (LI et al., 2009; OAKLEY, ABBOTT, et al., 2009; OAKLEY, SMITH, et al., 2009).

Esta resposta é bastante interessante, pois tudo leva a crer que a sinalização redox é compartimentalizada, uma vez que para ser efetiva e inócua deve ser restrita a alvos específicos. O fato de ela ser estimulada pela ligação de citocinas à receptores de membrana mostra como essa resposta é fisiológica e, na verdade, pode ocorrer muito mais comumente do que imaginamos (SPENCER; ENGELHARDT, 2014). Os testes com as células INS-1E e a sonda Oxyburst ${ }^{\circledR}$ mostraram que as mesmas não apresentam formação de redoxossomas em resposta a IL-1 $\beta$ ou glicose. Entretanto, já foi reportada a presença de Nox2 em endossomas nas células beta pancreáticas, sendo que estes não eram grânulos de insulina, o que são indicativos da presença desta organela sinalizadora (LI et al., 2012). Entretanto, ainda não foi confirmada a formação de superóxido no interior da mesma e nem quais estímulos a causam. Pode ser que no futuro venha a ser confirmada a ocorrência dos redoxossomas nas células produtoras de insulina, pois apesar de terem sido testados vários protocolos diferentes por citometria de fluxo e microscopia de fluorescência confocal, este não é um evento fácil de ser observado, já que se trata de vesículas redox lábeis de diâmetro bem diminuto, entre 100 a $300 \mathrm{~nm}$ (Ll et al., 2009).

Por fim, apesar de sabermos que a glicose é capaz de modular o estado redox nas células beta pancreáticas, alterando o conteúdo de superóxido nos diferentes compartimentos celulares e a resposta antioxidante, e que este influencia eventos tão importantes quanto a secreção de insulina e a morte celular, ainda há muito mais a ser investigado. Com o desenvolvimento de sondas e técnicas mais apuradas para medir EROs e a proteômica redox, seremos capazes de delimitar com precisão os alvos moleculares específicos das EROs produzidas, entender melhor a compartimentalização dessa produção e 
o papel fisiológico desempenhado especificamente por cada Nox presente (Nox2, 4 e 5) nas células beta pancreáticas e a cadeia mitocondrial. Só assim conseguiremos acertar os alvos farmacológicos tão intensamente procurados, que possam evitar ou atenuar o estresse oxidativo, a disfunção e a morte celular causadores do diabetes, um dos grandes males desse início do século XXI. 
9

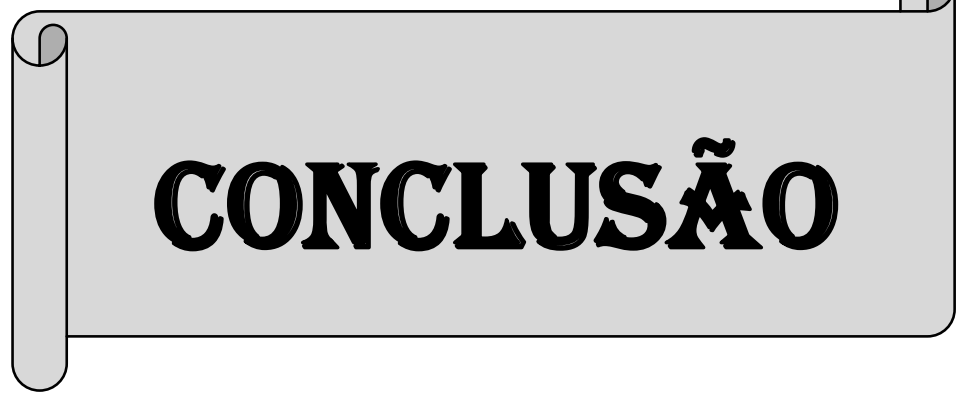




\section{CONCLUSÃo}

Através dos experimentos realizados observamos que, ao contrário do que se acreditava anteriormente, a incubação na presença de baixas concentrações de glicose culmina em conteúdos maiores de espécies reativas de oxigênio. Entretanto, a glicose modula não só a produção de superóxido via NADPH oxidase e mitocôndria, mas também o sistema antioxidante, com diminuição da concentração de glutationa reduzida na presença de baixa glicose e alteração da expressão de algumas enzimas antioxidantes. Deste modo, o conteúdo de superóxido é bem maior, especialmente após 48 horas de incubação em 2,8 $\mathrm{mM}$ de glicose, assim como a morte celular. A baixa glicose é mais deletéria para ilhotas pancreáticas em cultura do que a alta glicose. Além disso, alterações como a inibição de Sod1 são capazes de diminuir a resposta da secreção de insulina estimulada por glicose. A interação entre rac1/sod1 foi demonstrada pela primeira vez nas células produtoras de insulina e também que esta é modificada pela glicose, pois está aumentada em 20 mM. Nos testes realizados não observamos a geração dos redoxossomas em resposta à glicose nestas células. Por fim, concluímos que a glicose é capaz de alterar o estado redox das células beta pancreáticas modulando a produção de espécies reativas de oxigênio, a atividade e conteúdo dos componentes do sistema antioxidante, o que reflete em eventos chave como a secreção de insulina e a morte celular, reafirmando mais uma vez como o estado redox participa tanto de eventos fisiológicos quanto fisiopatológicos neste tecido endócrino. 


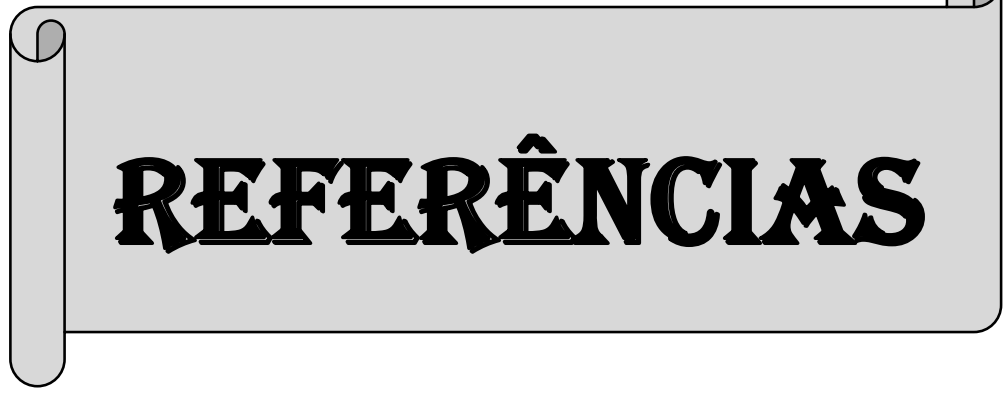




\section{REFERÊNCIAS*}

AKERBOOM, T. P.; SIES, H. Assay of glutathione, glutathione disulfide, and glutathione mixed disulfides in biological samples. Methods Enzymol; v. 77, p. 373-382. 1981.

ALBERTS, B. et al. Molecular Biology of the Cell. New York: Garland Science, 2002. 1463 p.

AOYAMA, T. et al. Nicotinamide adenine dinucleotide phosphate oxidase (nox) in experimental liver fibrosis: GKT137831 as a novel potential therapeutic agent. Hepatology, 2012.

AUGUSTO, O. Radicais Livres - bons, maus e naturais. São Paulo: Oficina de Textos, 2006. 115 p.

BABIOR, B. M. NADPH oxidase: an update. Blood, v. 93, n. 5, p. 1464-1476. 1999.

BARTOSZ, G. Reactive oxygen species: destroyers or messengers? Biochem. Pharmacol; v. 77, n. 8, p. 1303-1315. 2009.

BEDARD, K.; KRAUSE, K. H. The NOX family of ROS-generating NADPH oxidases: physiology and pathophysiology. Physiol Rev, v. 87, n. 1, p. 245-313. 2007.

BEDARD, K. et al. NOX family NADPH oxidases: not just in mammals. Biochimie, v. 89, n. 9, p. 11071112. 2007.

BEFFY, P. et al. A constitutive nitric oxide synthase modulates insulin secretion in the INS-1 cell line. Mol Cell Endocrinol, v. 183, n. 1-2, p. 41-48. 2001.

BENSELLAM, M. et al. Cluster analysis of rat pancreatic islet gene mRNA levels after culture in low-, intermediate- and high-glucose concentrations. Diabetologia, v. 52, n. 3, p. 463-476. 2009.

BESKE, P. H.; JACKSON, D. A. NADPH oxidase mediates the oxygen-glucose deprivation/reperfusioninduced increase in the tyrosine phosphorylation of the N-methyl-D-aspartate receptor NR2A subunit in retinoic acid differentiated SH-SY5Y Cells. J Mol Signal, v. 7, n. 1, p. 15. 2012.

BINDOKAS, V. P. et al. Visualizing superoxide production in normal and diabetic rat islets of Langerhans. J Biol Chem, v. 278, n. 11, p. 9796-9801. 2003.

* De acordo com:

ASSOCIAÇÃO BRASILEIRA DE NORMAS TÉCNICAS. NBR 6023: informação e documentação: referências: elaboração. Rio de Janeiro, 2002. 
BISWAS, S. et al. Redox modifications of protein-thiols: emerging roles in cell signaling. Biochem Pharmacol, v. 71, n. 5, p. 551-564. 2006.

BONORA, M. et al. ATP synthesis and storage. Purinergic Signal, v. 8, n. 3, p. 343-357. 2012.

BRÉCHARD, S. et al. New insights into the regulation of neutrophil NADPH oxidase activity in the phagosome: a focus on the role of lipid and $\mathrm{Ca}(2+)$ signaling. Antioxid Redox Signal, v. 18, n. 6, p. 661676. 2013.

BUTTERFIELD, D. A.; DALLE-DONNE, I. Redox proteomics: from protein modifications to cellular dysfunction and disease. Mass Spectrom Rev, v. 33, n. 1, p. 1-6. 2014.

CORCORAN, A.; COTTER, T. G. Redox regulation of protein kinases. FEBS J, v. 280, n. 9, p. 1944-1965. 2013.

D'ALESSANDRO, A.; ZOLLA, L. The SODyssey: superoxide dismutases from biochemistry, through proteomics, to oxidative stress, aging and nutraceuticals. Expert Rev Proteomics, v. 8, n. 3, p. 405421. 2011.

DAMMEYER, P.; ARNÉR, E. S. Human Protein Atlas of redox systems - what can be learnt? Biochim Biophys Acta, v. 1810, n. 1, p. 111-138. 2011.

DANAEI, G. et al. National, regional, and global trends in fasting plasma glucose and diabetes prevalence since 1980: systematic analysis of health examination surveys and epidemiological studies with 370 country-years and 2.7 million participants. Lancet, v. 378, n. 9785, p. 31-40. 2011.

DELEO, F. R. et al. Processing and maturation of flavocytochrome b558 include incorporation of heme as a prerequisite for heterodimer assembly. J Biol Chem, v. 275, n. 18, p. 13986-13993. 2000.

DETIMARY, P. et al. The changes in adenine nucleotides measured in glucose-stimulated rodent islets occur in beta cells but not in alpha cells and are also observed in human islets. J Biol Chem, v. 273, n. 51, p. 33905-33908. 1998.

DICKINSON, B. C.; CHANG, C. J. Chemistry and biology of reactive oxygen species in signaling or stress responses. Nat Chem Biol, v. 7, n. 8, p. 504-511. 2011.

DIKALOV, S. Cross talk between mitochondria and NADPH oxidases. Free Radic Biol Med, v. 51, n. 7, p. 1289-1301. 2011.

DIKALOV, S. I. et al. Nox2-Induced Production of Mitochondrial Superoxide in Angiotensin IIMediated Endothelial Oxidative Stress and Hypertension. Antioxid Redox Signal, v. 20, n. 2, p. 281294. 2014. 
DIKALOVA, A. E. et al. Therapeutic targeting of mitochondrial superoxide in hypertension. Circ Res, v. 107, n. 1, p. 106-116. 2010.

DOTAN, Y. et al. Lipid peroxidation cannot be used as a universal criterion of oxidative stress. Prog Lipid Res, v. 43, n. 3, p. 200-227. 2004.

DOTAN, Y. et al. No evidence supports vitamin E indiscriminate supplementation. Biofactors, v. 35, n. 6, p. 469-473. 2009.

DOTAN, Y. et al. Decision analysis supports the paradigm that indiscriminate supplementation of vitamin E does more harm than good. Arterioscler Thromb Vasc Biol, v. 29, n. 9, p. 1304-1309. 2009.

DUPREZ, J. et al. Protective antioxidant and antiapoptotic effects of $\mathrm{ZnCl} 2$ in rat pancreatic islets cultured in low and high glucose concentrations. PLoS One, v. 7, n. 10, p. e46831. 2012.

EFANOVA, I. B. et al. Glucose and tolbutamide induce apoptosis in pancreatic beta-cells. A process dependent on intracellular Ca2+ concentration. J Biol Chem, v. 273, n. 50, p. 33501-33507. 1998.

ELOUIL, H. et al. Acute nutrient regulation of the unfolded protein response and integrated stress response in cultured rat pancreatic islets. Diabetologia, v. 50, n. 7, p. 1442-1452. 2007.

FRIDOVICH, I. Oxygen: how do we stand it? Med Princ Pract, v. 22, n. 2, p. 131-137. 2013.

FUNK, S. D. et al. Hyperglycemia and endothelial dysfunction in atherosclerosis: lessons from type 1 diabetes. Int J Vasc Med, v. 2012, p. 569654. 2012.

GAO, L.; MANN, G. E. Vascular NAD(P)H oxidase activation in diabetes: a double-edged sword in redox signalling. Cardiovasc Res, v. 82, n. 1, p. 9-20. 2009.

GAO, Y. et al. Rational design and characterization of a Rac GTPase-specific small molecule inhibitor. Proc Natl Acad Sci U S A, v. 101, n. 20, p. 7618-7623. 2004.

GEISZT, M.; LETO, T. L. The Nox family of NAD(P)H oxidases: host defense and beyond. J Biol Chem, v. 279, n. 50, p. 51715-51718. 2004.

GERSCHMAN, R. et al. Oxygen poisoning and x-irradiation: a mechanism in common. Science, v. 119, n. 3097, p. 623-626. 1954.

GLADYSHEV, V. N. The free radical theory of aging is dead. Long live the damage theory! Antioxid Redox Signal, v. 20, n. 4, p. 727-731. 2014. 
GOLDSTEIN, B. J. et al. Redox paradox: insulin action is facilitated by insulin-stimulated reactive oxygen species with multiple potential signaling targets. Diabetes, v. 54, n. 2, p. 311-321. 2005.

GORIN, Y.; BLOCK, K. Nox as a target for diabetic complications. Clin Sci (Lond), v. 125, n. 8, p. 361382. 2013.

GRAHAM, N. A. et al. Glucose deprivation activates a metabolic and signaling amplification loop leading to cell death. Mol Syst Biol, v. 8, p. 589. 2012.

GRANKVIST, K. et al. CuZn-superoxide dismutase, Mn-superoxide dismutase, catalase and glutathione peroxidase in pancreatic islets and other tissues in the mouse. Biochem J, v. 199, n. 2, p. 393-398. 1981.

HALLIWELL, B.; GUTTERIDGE, J. M. C. Free Radicals in Biology and Medicine: Oxford university Press. 1999

HANCOCK, J. T. The role of redox mechanisms in cell signalling. Mol Biotechnol, v. 43, n. 2, p. 162166. 2009.

HARMAN, D. Aging: a theory based on free radical and radiation chemistry. J Gerontol, v. 11, n. 3, p. 298-300. 1956.

HARRAZ, M. M. et al. SOD1 mutations disrupt redox-sensitive Rac regulation of NADPH oxidase in a familial ALS model. J Clin Invest, v. 118, n. 2, p. 659-670. 2008.

HEO, J.; CAMPBELL, S. L. Mechanism of redox-mediated guanine nucleotide exchange on redox-active Rho GTPases. J Biol Chem, v. 280, n. 35, p. 31003-31010. 2005.

HOHMEIER, H. E. et al. Isolation of INS-1-derived cell lines with robust ATP-sensitive K+ channeldependent and -independent glucose-stimulated insulin secretion. Diabetes, v. 49, n. 3, p. 424-430. 2000.

HOLMGREN, A. Antioxidant function of thioredoxin and glutaredoxin systems. Antioxid Redox Signal, v. 2, n. 4, p. 811-820. 2000.

HORDIJK, P. L. Regulation of NADPH oxidases: the role of Rac proteins. Circ Res, v. 98, n. 4, p. 453462. 2006.

IVARSSON, R. et al. Redox control of exocytosis: regulatory role of NADPH, thioredoxin, and glutaredoxin. Diabetes, v. 54, n. 7, p. 2132-2142. 2005. 
JANJIC, D.; WOLLHEIM, C. B. Islet cell metabolism is reflected by the MTT (tetrazolium) colorimetric assay. Diabetologia, v. 35, n. 5, p. 482-485. 1992.

JEŽEK, P. et al. Redox homeostasis in pancreatic $\beta$ cells. Oxid Med Cell Longev, v. 2012, p. 932838. 2012.

JONES, D. P. Extracellular redox state: refining the definition of oxidative stress in aging. Rejuvenation Res, v. 9, n. 2, p. 169-181. 2006.

JUAREZ, J. C. et al. Superoxide dismutase 1 (SOD1) is essential for H2O2-mediated oxidation and inactivation of phosphatases in growth factor signaling. Proc Natl Acad Sci U S A, v. 105, n. 20, p. 7147-7152. 2008.

KALYANARAMAN, B. Teaching the basics of redox biology to medical and graduate students: Oxidants, antioxidants and disease mechanisms. Redox Biol, v. 1, n. 1, p. 244-257. 2013.

KALYANARAMAN, B. et al. HPLC-based monitoring of products formed from hydroethidine-based fluorogenic probes--the ultimate approach for intra- and extracellular superoxide detection. Biochim Biophys Acta, v. 1840, n. 2, p. 739-744. 2014.

KAMENCIC, $\mathrm{H}$. et al. Monochlorobimane fluorometric method to measure tissue glutathione. Anal Biochem, v. 286, n. 1, p. 35-37. 2000.

KANG, L. et al. Heterozygous SOD2 Deletion Impairs Glucose-Stimulated Insulin Secretion, but not Insulin Action in High Fat-Fed Mice. Diabetes. 2014.

KIRSCH, M.; DE GROOT, H. NAD(P)H, a directly operating antioxidant? FASEB J, v. 15, n. 9, p. 15691574. 2001.

KLENIEWSKA, P. et al. The NADPH oxidase family and its inhibitors. Arch Immunol Ther Exp (Warsz), v. 60, n. 4, p. 277-294. 2012.

KRAUSS, S. et al. Superoxide-mediated activation of uncoupling protein 2 causes pancreatic beta cell dysfunction. J Clin Invest, v. 112, n. 12, p. 1831-1842. 2003.

KRÖLLER-SCHÖN, S. et al. Molecular mechanisms of the crosstalk between mitochondria and NADPH oxidase through reactive oxygen species-studies in white blood cells and in animal models. Antioxid Redox Signal, v. 20, n. 2, p. 247-266. 2014. 
KUTSCHERA, U.; NIKLAS, K. J. Metabolic scaling theory in plant biology and the three oxygen paradoxa of aerobic life. Theory Biosci. 2013.

LACY, P. E.; KOSTIANOVSKY, M. Method for the isolation of intact islets of Langerhans from the rat pancreas. Diabetes, v. 16, n. 1, p. 35-39. 1967.

LAMBETH, J. D. et al. Regulation of Nox and Duox enzymatic activity and expression. Free Radic Biol Med, v. 43, n. 3, p. 319-331. 2007.

LEE, M. Y.; GRIENDLING, K. K. Redox signaling, vascular function, and hypertension. Antioxid Redox Signal, v. 10, n. 6, p. 1045-1059. 2008.

LELOUP, $C$. et al. Mitochondrial reactive oxygen species are obligatory signals for glucose-induced insulin secretion. Diabetes, v. 58, n. 3, p. 673-681. 2009.

LENZEN, S. et al. Low antioxidant enzyme gene expression in pancreatic islets compared with various other mouse tissues. Free Radic Biol Med, v. 20, n. 3, p. 463-466. 1996.

LI, J. et al. Novel regulation by Rac1 of glucose- and forskolin-induced insulin secretion in INS-1 betacells. Am J Physiol Endocrinol Metab, v. 286, n. 5, p. E818-827. 2004.

LI, N. et al. NADPH Oxidase NOX2 Defines a New Antagonistic Role for Reactive Oxygen Species and cAMP/PKA in the Regulation of Insulin Secretion. Diabetes. 2012.

LI, Q. et al. Endosomal Nox2 facilitates redox-dependent induction of NF-kappaB by TNF-alpha. Antioxid Redox Signal, v. 11, n. 6, p. 1249-1263. 2009.

LIVAK, K. J.; SCHMITTGEN, T. D. Analysis of relative gene expression data using real-time quantitative PCR and the 2(-Delta Delta C(T)) Method. Methods, v. 25, n. 4, p. 402-408. 2001.

LORTZ, S. et al. Overexpression of the antioxidant enzyme catalase does not interfere with the glucose responsiveness of insulin-secreting INS-1E cells and rat islets. Diabetologia, v. 56, n. 4, p. 774782. 2013.

MA, Z. et al. Hyperoxia inhibits glucose-induced insulin secretion and mitochondrial metabolism in rat pancreatic islets. Biochem Biophys Res Commun, v. 443, n. 1, p. 223-228. 2014.

MARTENS, G. A. et al. Glucose suppresses superoxide generation in metabolically responsive pancreatic beta cells. J Biol Chem, v. 280, n. 21, p. 20389-20396. 2005.

MARZZOCO, A.; TORRES, B. B. Bioquímica Básica: Guanabara Koogan, 1999. 360p. 
MCCORD, J. M.; FRIDOVICH, I. Superoxide dismutase. An enzymic function for erythrocuprein (hemocuprein). J Biol Chem, v. 244, n. 22, p. 6049-6055. 1969.

MERGLEN, A. et al. Glucose sensitivity and metabolism-secretion coupling studied during two-year continuous culture in INS-1E insulinoma cells. Endocrinology, v. 145, n. 2, p. 667-678. 2004.

MIRCETA, S. et al. Evolution of mammalian diving capacity traced by myoglobin net surface charge. Science, v. 340, n. 6138, p. 1234192. 2013.

MIYANO, K.; SUMIMOTO, H. Role of the small GTPase Rac in p22phox-dependent NADPH oxidases. Biochimie, v. 89, n. 9, p. 1133-1144. 2007.

MODAK, M. A. et al. Control of hyperglycemia significantly improves oxidative stress profile of pancreatic islets. Islets, v. 3, n. 5, p. 234-240. 2011.

MORGAN, D. et al. Glucose, palmitate and pro-inflammatory cytokines modulate production and activity of a phagocyte-like NADPH oxidase in rat pancreatic islets and a clonal beta cell line. Diabetologia, v. 50, n. 2, p. 359-369. 2007.

MORGAN, D. et al. Association of $\mathrm{NAD}(\mathrm{P}) \mathrm{H}$ oxidase with glucose-induced insulin secretion by pancreatic beta-cells. Endocrinology, v. 150, n. 5, p. 2197-2201. 2009.

MOSMANN, T. Rapid colorimetric assay for cellular growth and survival: application to proliferation and cytotoxicity assays. J Immunol Methods, v. 65, n. 1-2, p. 55-63. 1983.

MOUNTJOY, P. D.; RUTTER, G. A. Glucose sensing by hypothalamic neurones and pancreatic islet cells: AMPle evidence for common mechanisms? Exp Physiol, v. 92, n. 2, p. 311-319. 2007.

NAUSEEF, W. M. Biological roles for the NOX family NADPH oxidases. J Biol Chem, v. 283, n. 25, p. 16961-16965. 2008.

NAUSEEF, W. M. Detection of superoxide anion and hydrogen peroxide production by cellular NADPH oxidases. Biochim Biophys Acta, v. 1840, n. 2, p. 757-767. 2014.

OAKLEY, F. D. et al. Signaling components of redox active endosomes: the redoxosomes. Antioxid Redox Signal, v. 11, n. 6, p. 1313-1333. 2009.

OAKLEY, F. D. et al. Lipid rafts and caveolin-1 coordinate interleukin-1beta (IL-1beta)-dependent activation of NFkappaB by controlling endocytosis of Nox 2 and IL-1beta receptor 1 from the plasma membrane. J Biol Chem, v. 284, n. 48, p. 33255-33264. 2009. 
OLIVEIRA, H. R. et al. Glucose induces an acute increase of superoxide dismutase activity in incubated rat pancreatic islets. Am J Physiol, v. 276, n. 2 Pt 1, p. C507-510. 1999.

OLIVEIRA, H. R. et al. Pancreatic beta-cells express phagocyte-like NAD(P)H oxidase. Diabetes, v. 52, n. 6, p. 1457-1463. 2003.

OMS, O. M. D. S. http://www.who.int/features/factfiles/diabetes/en/. 20142013.

PASCAL, S. M. et al. Effects of fructosamine-3-kinase deficiency on function and survival of mouse pancreatic islets after prolonged culture in high glucose or ribose concentrations. Am J Physiol Endocrinol Metab, v. 298, n. 3, p. E586-596. 2010.

PFAFFL, M. W. A new mathematical model for relative quantification in real-time RT-PCR. Nucleic Acids Res, v. 29, n. 9, p. e45. 2001.

$\mathrm{PI}$, J. et al. Reactive oxygen species as a signal in glucose-stimulated insulin secretion. Diabetes, v. 56, n. 7, p. 1783-1791. 2007.

PONTING, C. P. Novel domains in NADPH oxidase subunits, sorting nexins, and Ptdlns 3-kinases: binding partners of SH3 domains? Protein Sci, v. 5, n. 11, p. 2353-2357. 1996.

POUNGVARIN, N. et al. Carbohydrate response element-binding protein (ChREBP) plays a pivotal role in beta cell glucotoxicity. Diabetologia, v. 55, n. 6, p. 1783-1796. 2012.

POUR, P. M.; SARUC, M. The pattern of neural elements in the islets of normal and diseased pancreas and in isolated islets. JOP, v. 12, n. 4, p. 395-403. 2011.

RAKHIT, R.; CHAKRABARTTY, A. Structure, folding, and misfolding of $\mathrm{Cu}, \mathrm{Zn}$ superoxide dismutase in amyotrophic lateral sclerosis. Biochim Biophys Acta, v. 1762, n. 11-12, p. 1025-1037. 2006.

REBELATO, E. et al. Control of the intracellular redox state by glucose participates in the insulin secretion mechanism. PLoS One, v. 6, n. 8, p. e24507. 2011.

ROCHETTE, L. et al. Diabetes, oxidative stress and therapeutic strategies. Biochim Biophys Acta. 2014.

ROMA, L. P. et al. Mitochondrial oxidative stress contributes differently to rat pancreatic islet cell apoptosis and insulin secretory defects after prolonged culture in a low non-stimulating glucose concentration. Diabetologia, v. 55, n. 8, p. 2226-2237. 2012. 
SARRE, A. et al. Reactive oxygen species are produced at low glucose and contribute to the activation of AMPK in insulin-secreting cells. Free Radic Biol Med, v. 52, n. 1, p. 142-150. 2012.

SAYIN, V. I. et al. Antioxidants accelerate lung cancer progression in mice. Sci Transl Med, v. 6, n. 221, p. 221ra215. 2014.

SCHELLENBERG, E. S. et al. Lifestyle interventions for patients with and at risk for type 2 diabetes: a systematic review and meta-analysis. Ann Intern Med, v. 159, n. 8, p. 543-551. 2013.

SCHULZ, E. et al. Mitochondrial redox signaling: Interaction of mitochondrial reactive oxygen species with other sources of oxidative stress. Antioxid Redox Signal, v. 20, n. 2, p. 308-324. 2014.

SKELIN, M. et al. Pancreatic beta cell lines and their applications in diabetes mellitus research. ALTEX, v. 27, n. 2, p. 105-113. 2010.

SPENCER, N. Y.; ENGELHARDT, J. F. The basic biology of redoxosomes in cytokine-mediated signal transduction and implications for disease-specific therapies. Biochemistry, v. 53, n. 10, p. 1551-1564. 2014.

SPERLING, E. A. et al. Oxygen, ecology, and the Cambrian radiation of animals. Proc Natl Acad Sci U S A, v. 110, n. 33, p. 13446-13451. 2013.

SUMIMOTO, H. Structure, regulation and evolution of Nox-family NADPH oxidases that produce reactive oxygen species. FEBS J, v. 275, n. 13, p. 3249-3277. 2008.

SYED, I. et al. Tiam1/Rac1 signaling pathway mediates palmitate-induced, ceramide-sensitive generation of superoxides and lipid peroxides and the loss of mitochondrial membrane potential in pancreatic beta-cells. Biochem Pharmacol, v. 80, n. 6, p. 874-883. 2010.

SYED, I. et al. Increased phagocyte-like NADPH oxidase and ROS generation in type 2 diabetic ZDF rat and human islets: role of Rac1-JNK1/2 signaling pathway in mitochondrial dysregulation in the diabetic islet. Diabetes, v. 60, n. 11, p. 2843-2852. 2011.

TAKAHASHI, H. K. et al. Acute nutrient regulation of the mitochondrial glutathione redox state in pancreatic $\beta$-cells. Biochem J, v. 460, n. 3, p. 411-423. 2014.

TANG, C. et al. Glucose-induced beta cell dysfunction in vivo in rats: link between oxidative stress and endoplasmic reticulum stress. Diabetologia, v. 55, n. 5, p. 1366-1379. 2012.

TIEDGE, M. et al. Relation between antioxidant enzyme gene expression and antioxidative defense status of insulin-producing cells. Diabetes, v. 46, n. 11, p. 1733-1742. 1997. 
TOWBIN, $\mathrm{H}$. et al. Electrophoretic transfer of proteins from polyacrylamide gels to nitrocellulose sheets: procedure and some applications. Proc Natl Acad Sci U S A, v. 76, n. 9, p. 4350-4354. 1979.

USHIO-FUKAI, M. Compartmentalization of redox signaling through NADPH oxidase-derived ROS. Antioxid Redox Signal, v. 11, n. 6, p. 1289-1299. 2009.

VELUTHAKAL, R. et al. Regulatory roles for Tiam1, a guanine nucleotide exchange factor for Rac1, in glucose-stimulated insulin secretion in pancreatic beta-cells. Biochem Pharmacol, v. 77, n. 1, p. 101113. 2009.

WALI, J. A. et al. The proapoptotic BH3-only proteins Bim and Puma are downstream of endoplasmic reticulum and mitochondrial oxidative stress in pancreatic islets in response to glucotoxicity. Cell Death Dis, v. 5, p. e1124. 2014.

WALLACE, M. A. et al. Superoxide inhibits 4Fe-4S cluster enzymes involved in amino acid biosynthesis. Cross-compartment protection by CuZn-superoxide dismutase. J Biol Chem, v. 279, n. 31, p. 32055-32062. 2004.

WANG, L. et al. 14,15-EET promotes mitochondrial biogenesis and protects cortical neurons against oxygen/glucose deprivation-induced apoptosis. Biochem Biophys Res Commun. 2014.

WANG, X. et al. Knockouts of SOD1 and GPX1 exert different impacts on murine islet function and pancreatic integrity. Antioxid Redox Signal, v. 14, n. 3, p. 391-401. 2011.

WATSON, J. Oxidants, antioxidants and the current incurability of metastatic cancers. Open Biol, v. 3, n. 1, p. 120144. 2013.

WAYPA, G. B. et al. Superoxide generated at mitochondrial complex III triggers acute responses to hypoxia in the pulmonary circulation. Am J Respir Crit Care Med, v. 187, n. 4, p. 424-432. 2013.

WEBB, G. C. et al. Expression profiling of pancreatic beta cells: glucose regulation of secretory and metabolic pathway genes. Proc Natl Acad Sci U S A, v. 97, n. 11, p. 5773-5778. 2000.

WINGLER, K. et al. NOX1, 2, 4, 5: counting out oxidative stress. Br J Pharmacol, v. 164, n. 3, p. 866883. 2011.

WOO, H. A. et al. Inactivation of peroxiredoxin I by phosphorylation allows localized $\mathrm{H}(2) \mathrm{O}(2)$ accumulation for cell signaling. Cell, v. 140, n. 4, p. 517-528. 2010. 
YAMAMORI, T. et al. Roles of p38 MAPK, PKC and PI3-K in the signaling pathways of NADPH oxidase activation and phagocytosis in bovine polymorphonuclear leukocytes. FEBS Lett, v. 467, n. 2-3, p. 253-258. 2000.

YANG, X. J. et al. Hypothalamic glucose sensor: similarities to and differences from pancreatic betacell mechanisms. Diabetes, v. 48, n. 9, p. 1763-1772. 1999.

YU, Q. et al. Elimination of NADPH oxidase activity promotes reductive stress and sensitizes the heart to ischemic injury. J Am Heart Assoc, v. 3, n. 1, p. e000555. 2014.

ZHAO, H. et al. Superoxide reacts with hydroethidine but forms a fluorescent product that is distinctly different from ethidium: potential implications in intracellular fluorescence detection of superoxide. Free Radic Biol Med, v. 34, n. 11, p. 1359-1368. 2003. 


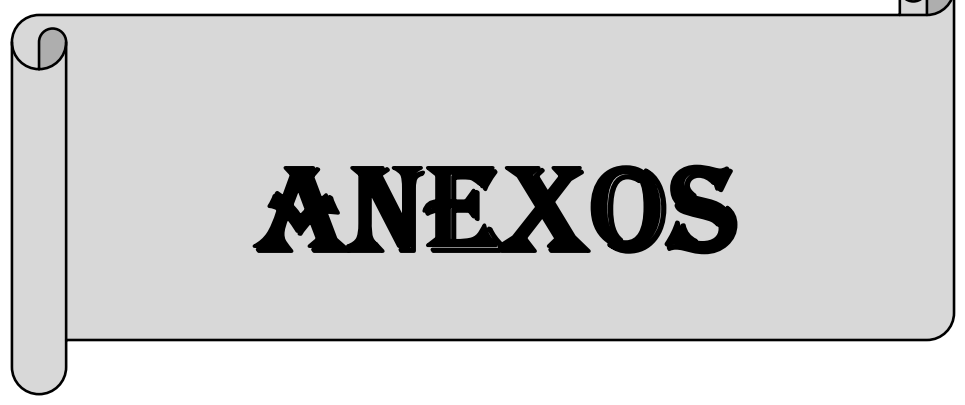




\section{ANEXOS - ARTIGOS PUBLICADOS}

1- Nunes VA, Portiolli-Sanches EP, Rosim MP, Araujo MS, Praxedes-Garcia P, Valle MM, Roma LP, Gurgul-Convey E, Lenzen S, Azevedo-Martins AK. Progesterone induces apoptosis of insulin-secreting cells: insights into the molecular mechanism. J Endocrinol., v. 22; n.221, p.273-84, 2014.

2 - Graciano MF, Valle MM, Kowluru A, Curi R, Carpinelli AR. Regulation of insulin secretion and reactive oxygen species production by free fatty acids in pancreatic islets. Islets, v. 5, n. 4, p. 139-48, 2013.

3 - Graciano MF, Valle MM, Kowluru A, Curi R, Carpinelli AR. Regulation of insulin secretion and reactive oxygen species production by free fatty acids in pancreatic islets. Islets, v. 3, n. 5, p. 213-23, 2011.

4 - Valle MM, Graciano MF, Lopes de Oliveira ER, Camporez JP, Akamine EH, Carvalho CR, Curi R, Carpinelli AR. Alterations of NADPH oxidase activity in rat pancreatic islets induced by a high-fat diet. Pancreas, v. 40, n. 3, p. 390-5, 2011. 